\title{
Saudi English as a foreign language learners' attitudes toward computer -assisted language learning
}

\author{
Mishal H. Al Shammari \\ West Virginia University
}

Follow this and additional works at: https://researchrepository.wvu.edu/etd

\section{Recommended Citation}

Al Shammari, Mishal H., "Saudi English as a foreign language learners' attitudes toward computer -assisted language learning" (2007). Graduate Theses, Dissertations, and Problem Reports. 4286.

https://researchrepository.wvu.edu/etd/4286

This Dissertation is protected by copyright and/or related rights. It has been brought to you by the The Research Repository @ WVU with permission from the rights-holder(s). You are free to use this Dissertation in any way that is permitted by the copyright and related rights legislation that applies to your use. For other uses you must obtain permission from the rights-holder(s) directly, unless additional rights are indicated by a Creative Commons license in the record and/ or on the work itself. This Dissertation has been accepted for inclusion in WVU Graduate Theses, Dissertations, and Problem Reports collection by an authorized administrator of The Research Repository @ WVU.

For more information, please contact researchrepository@mail.wvu.edu. 


\title{
Saudi English as a Foreign Language Learners' Attitudes Toward Computer-Assisted Language Learning
}

\author{
Mishal H. Al Shammari \\ Dissertation Submitted to the \\ College of Human Resources and Education \\ at West Virginia University \\ in partial fulfillment of the requirements \\ for the degree of \\ Doctor of Education \\ in \\ Curriculum and Instruction \\ Patricia Obenauf, Ed.D., Chairperson \\ Perry Philipps, Ed.D \\ David Callejo, Ed.D. \\ Ahmed Fakhri, Ph.D. \\ Ernest Goeres, Ph.D. \\ West Virginia University \\ Morgantown, WV 2007
}

Keywords: Saudi EFL learner attitudes, CALL in Saudi Arabia, computers and language learning

Copyright Mishal H. Al Shammari 


\title{
Saudi English as a Foreign Language Learners' Attitudes Toward Computer-Assisted Language Learning
}

\author{
Mishal H. Al Shammari
}

This study investigated Saudi English as a Foreign Language (EFL) Learners' attitudes toward Computer-Assisted Language Learning (CALL) at the Institute of Public Administration (IPA) in Saudi Arabia. Five research questions were developed: (1) What are the Saudi EFL learners' general attitudes toward CALL at the IPA? (2) What are Saudi EFL learners' attitudes toward the CALL software used at the IPA? (3) What are the differences between IPA Saudi EFL learners' attitudes toward CALL based on their years of English learning? (4) What are the differences between IPA Saudi EFL learners' attitudes toward CALL based on their current computer knowledge? (5) What are the differences between IPA Saudi EFL learners' attitudes toward CALL based on their gender?

The research questionnaire was administered to a total of 578 participants, including students from several levels of English language proficiency, major areas of study, and three distinct locations. Statistical methods including standard deviation, mean, regression analysis, and t-test were used to analyze data.

The findings indicated that the Saudi EFL learners' attitudes toward CALL and the software were positive. The results of the regression analysis showed that computer knowledge and gender served as the best predictors of learners' attitudes toward CALL. The t-test findings showed that Saudi female EFL learners had more positive attitudes toward CALL than their male counterparts.

The findings of this study will help to improve the use of CALL at the IPA and other college-level institutions in Saudi Arabia. 
TABLE OF CONTENTS

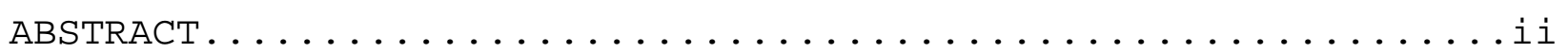

TABLE OF CONTENTS $\ldots \ldots \ldots \ldots \ldots \ldots \ldots \ldots \ldots \ldots \ldots \ldots \ldots \ldots \ldots \ldots \ldots \ldots \ldots \ldots$

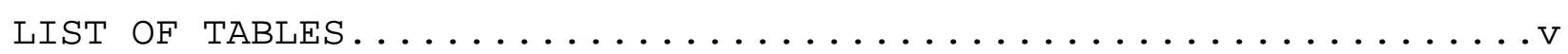

LIST OF FIGURES $\ldots \ldots \ldots \ldots \ldots \ldots \ldots \ldots \ldots \ldots \ldots \ldots \ldots \ldots \ldots \ldots \ldots \ldots \ldots$

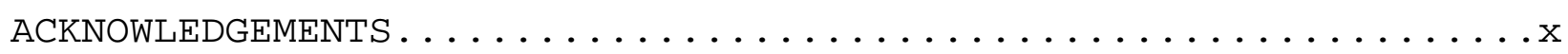

CHAPTER ONE: INTRODUCTION $\ldots \ldots \ldots \ldots \ldots \ldots \ldots \ldots \ldots \ldots \ldots \ldots \ldots$

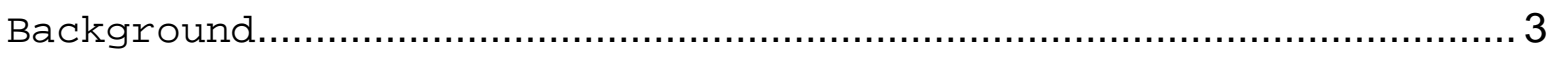

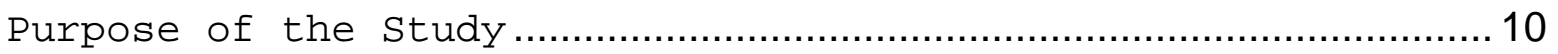

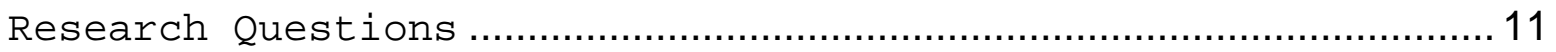

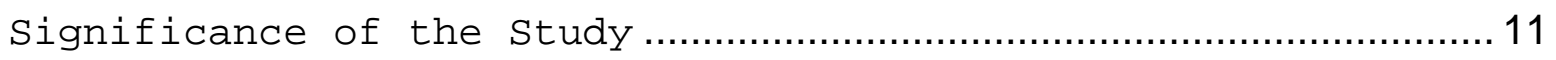

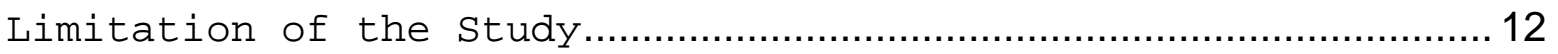

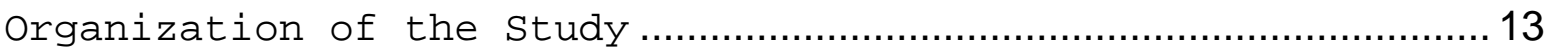

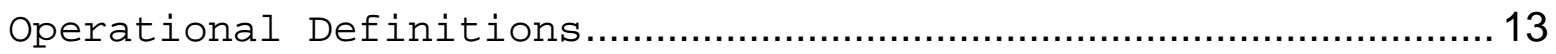

CHAPTER TWO: LITERATURE REVIEW.................... 16

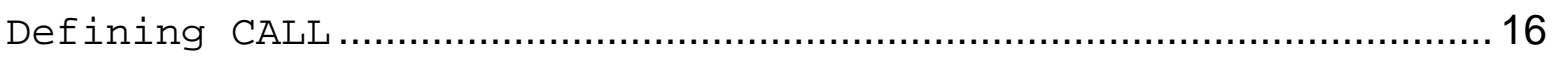

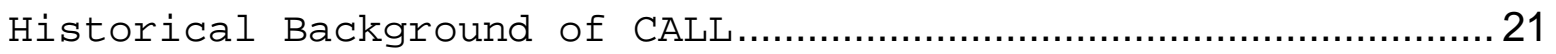

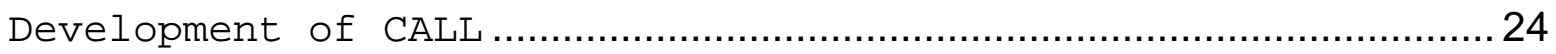

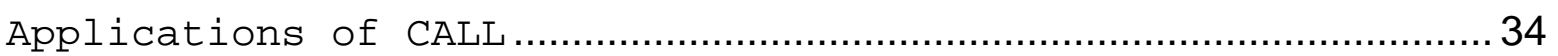

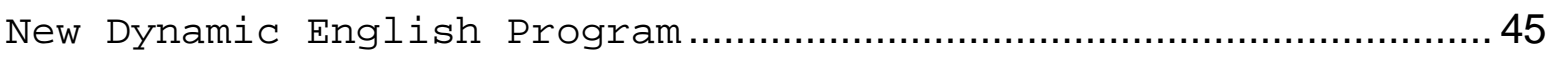

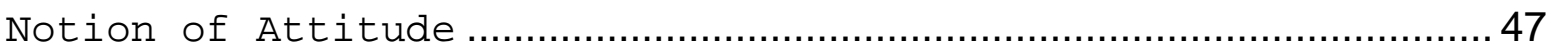

Attitude and Language Learning........................................................ 49

Attitude toward Computers in Instruction ....................................5 53

CHAPTER THREE: METHOdOLOGY....................65

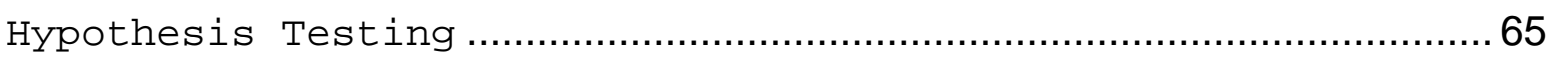

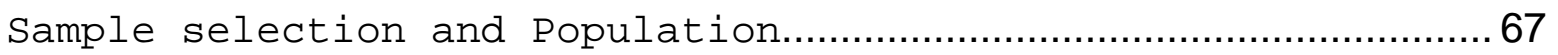

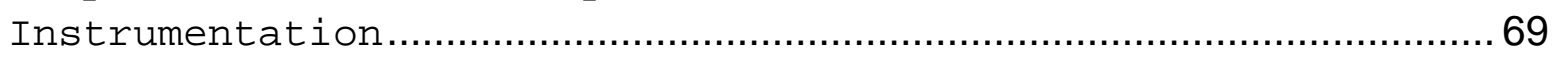

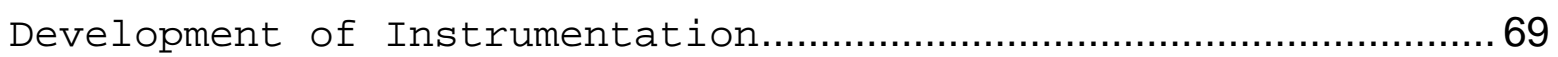

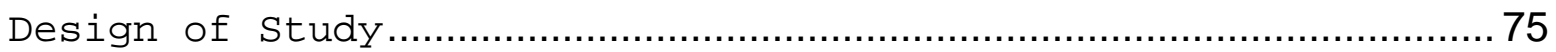

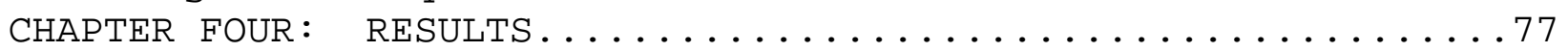

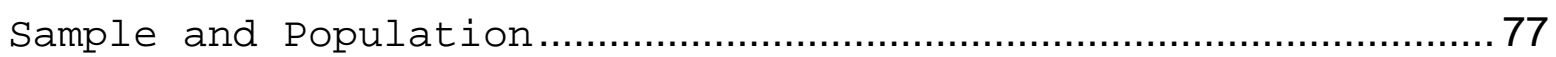

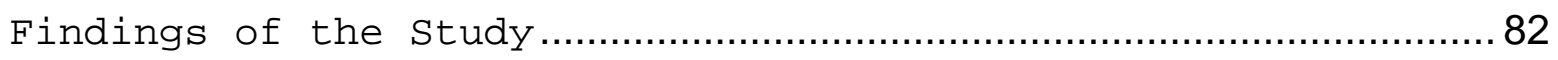

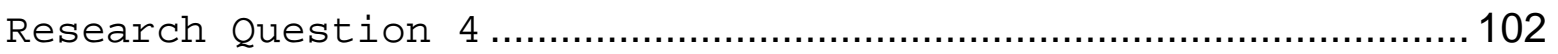

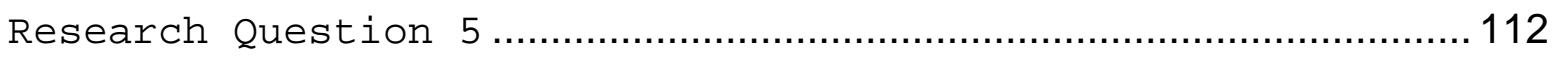


CHAPTER FIVE: SUMMARY, FINDINGS \& DISCUSSION, CONCLUSION, AND

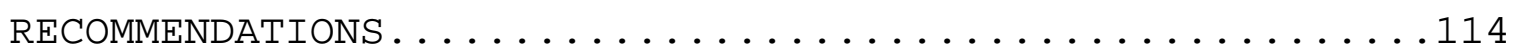

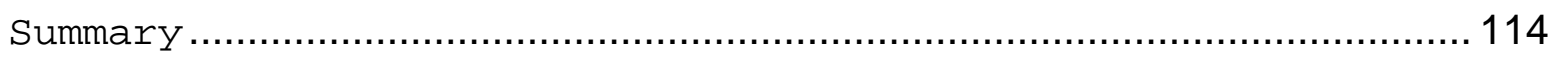

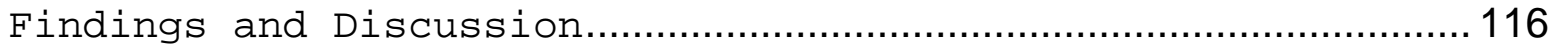

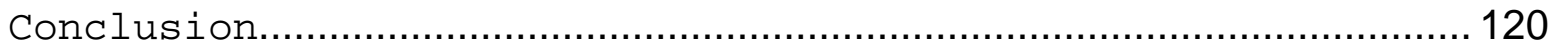

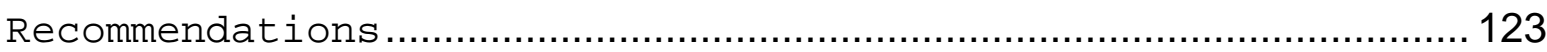

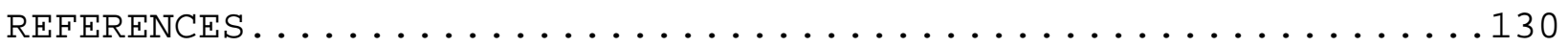

Appendix A: Survey Form (English Version) ...............142

Appendix B: The Arabic Version of the Survey

For Men and Women Students....................147

The Arabic Version of the Survey for Women Students..........153

Appendix C: Permission to Adopt CAS Survey................158

Permission to adopt SETA Survey...................... 160

Appendix D: Survey Evaluation Form..................161

Appendix E:Arabic Form of the Survey Evaluation............163

Appendix F: Human Participant Protections Approval..........165

Appendix G :Curriculum Vitae, Mishal H. Al Shammari.........166 


\section{LIST OF TABLES}

Table 2.1 The Three stages of CALL according to Warschauer's model.. 24 Figure 2.1 The Behaviorist Instructional Design ............ 25

Table 2.2. Bax's model of CALL.................... 33

Table 2.3. Contents of the New Dynamic English Software Levels..... 47

Table 3.1 Numbers of Saudi EFL learners at IPA Campuses........68

Table 4.1 Riyadh Men's Campus Response Rate...............78

Table 4.2 Riyadh Women's Campus Response Rate...............79

Table 4.3 Dammam Men's Campus Response Rate................88

Table 4.4 Jeddah Men's Campus Response Rate............... 81

Table 4.5 The Sample and Population of the Study............81

Table 4.6 Descriptive Statistics of Learners' General Attitudes toward

CALL at IPA Riyadh Men's Campus .................... 84

Table 4.7 Descriptive Statistics of Learners' General Attitudes toward

CALL at IPA Riyadh Women's Campus ................... 85

Table 4.8 Descriptive Statistics of Learners' General Attitudes

toward CALL at IPA Dammam Men's Campus ................87

Table 4.9 Descriptive Statistics of Learners' General Attitudes toward

CALL at IPA Jeddah Men's Campus ................... 88

Table. 4.10 Descriptive Statistics of Learners' General Attitudes

toward CALL at the Four IPA Campuses.................. 90

Table 4.11 Descriptive Statistics of Learners' Attitudes toward the

CALL Software at IPA Riyadh Men's Campus ................. 91

Table 4.12 Descriptive Statistics of Learners' Attitudes toward the

CALL Software at IPA Riyadh Women's Campus ................ 92 
Table 4.13 Descriptive Statistics of Learners' Attitudes toward the CALL Software at IPA Dammam Men's Campus.................94 Table 4.14 Descriptive Statistics of Learners' Attitudes toward the CALL Software at the IPA Jeddah Men's Campus.............. 95 Table. 4.15 Descriptive Statistics of Learners' Attitudes toward CALL

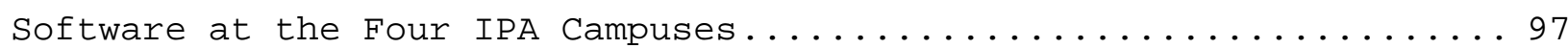
Table 4.16 Regression Model of Learners' Attitudes toward CALL Based on Their Years of English Learning at Riyadh Men's Campus......... 99 Table 4.17 Regression Model of Learners' Attitudes toward CALL Based on Their Years of English Learning at Riyadh Women's Campus....... 100 Table 4.18 Regression Model of Learners' Attitudes toward CALL Based on Their Years of English Learning at Dammam Men's Campus........ 101 Table 4.19 Regression Model of Learners' Attitudes toward CALL Based on Their Years of English Learning at Jeddah Men's Campus........ 102 Table 4.20 Regression Model of Learners' Attitudes toward CALL Based on Their Computer Knowledge at Riyadh Men's Campus............. 105 Table 4.21 Regression Model of Learners' Attitudes toward CALL Based on Their Computer Knowledge at Riyadh Men's Campus after Conducting Factor Analysis............................. 106 Table 4.22 Regression Model of Learners' Attitudes toward CALL Based on Their Computer Knowledge at Riyadh Women's Campus............ 107 Table 4.23 Regression Model of Learners' Attitudes toward CALL Based on Their Computer Knowledge at Riyadh Women's Campus after Conducting Factor Analysis ............................... 108 Table 4.24 Regression Model of Learners' Attitudes toward CALL Based on Their Computer Knowledge Dammam Men's Campus............... 109 
Table 4.25 Regression Model of Learners Attitudes toward CALL Based on Their Computer Knowledge at Dammam Men's Campus after Conducting Factor Analysis ............................. 110 Table 4.26 Regression Model of Learners' Attitudes toward CALL Based on Their Computer Knowledge at Jeddah Men's Campus........... 111 Table 4.27 Regression Model of Learners' Attitudes toward CALL Based on Their Computer Knowledge at Jeddah Men's Campus after Conducting

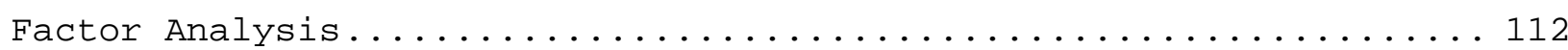
Table 4.28 t-test of Two Means of Learners' Attitudes toward CALL at Riyadh Women's and Men's Campus ................... 113 


\section{LIST OF FIGURES}

Figure 2.1 CALL and the Related Fields ................... 17

Figure 2.3 The Role of Krashen's Affective Filter Hypothesis on the

Second Language Learning and Production.................. 51

Figure 3.1 Instrumentation of the study................... 70

Figure 3.2 Independent Variables Used to Predict Learners' Attitudes

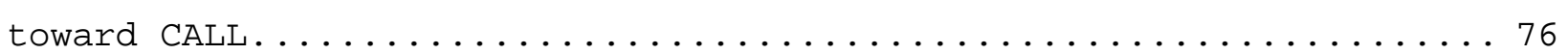

Figure 4.1 The Range of Learners' General Attitudes toward CALL at IPA Riyadh Men's Campus $\ldots \ldots \ldots \ldots \ldots \ldots \ldots \ldots \ldots \ldots \ldots \ldots \ldots$

Figure 4.2 The Range of Learners' General Attitudes toward CALL at IPA

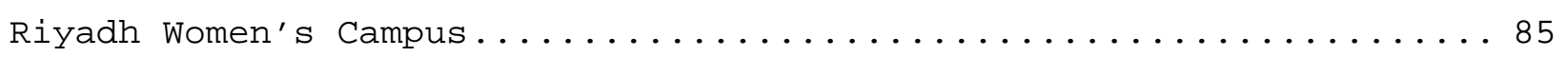

Figure 4.3 The Range of Learners' General Attitudes toward CALL at IPA

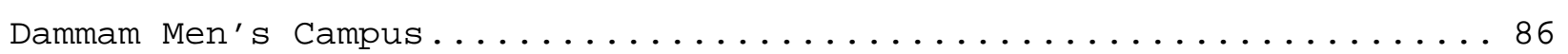

Figure 4.4 The Range of Learner's General Attitudes toward CALL at IPA

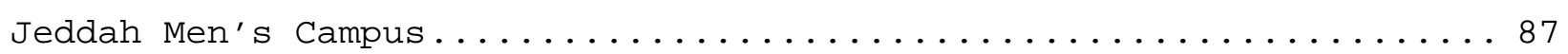
Figure 4.5 The Range of Learners' General Attitudes toward CALL at the

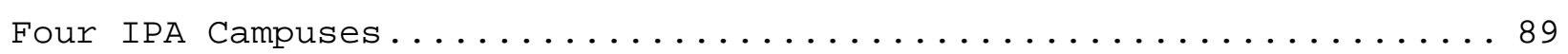

Figure 4.6 The Range of Learners' Attitudes toward CALL Software at IPA Riyadh Men's Campus $\ldots \ldots \ldots \ldots \ldots \ldots \ldots \ldots \ldots \ldots \ldots \ldots \ldots \ldots \ldots$ Figure 4.7 The Range of Learners' Attitudes toward CALL Software at IPA Riyadh Women's Campus $\ldots \ldots \ldots \ldots \ldots \ldots \ldots \ldots \ldots \ldots \ldots \ldots \ldots$ Figure 4.8 The Range of Learners' Attitudes toward CALL Software at

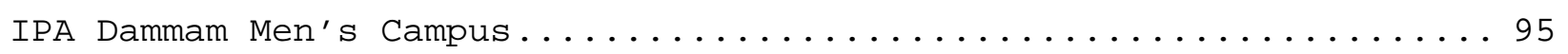
Figure 4.9 The Range of Learners' Attitudes toward CALL Software at

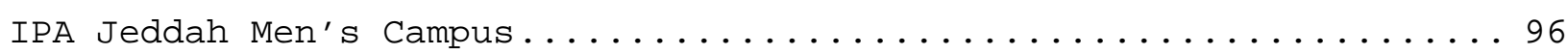


Figure 4.10 The Range of Learners' Attitudes toward CALL Software at

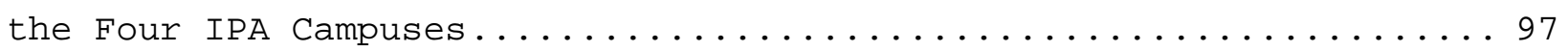




\section{ACKNOWLEDGEMENTS}

The completion of this dissertation could not be possible without the endless help of many people. After Allah, I would like to thank, first and foremost, my dissertation committee chair, Dr. Patricia obenauf. From the first class that I took with her during the summer of 2004, Dr. Obenauf provided me with knowledge and encouragement while also guiding me during my study at West Virginia University. Her inspiring input, comments, and suggestions have greatly improved this research. She also influenced me in all my life aspects. Dr. Obenauf was not only academic advisor, but also a mentor, friend, and guide.

I would also like to thank Dr. Perry Phillips. Dr. Phillips's willingness to help, discuss, and support my academic efforts represents a significant contribution to this project. I am thankful also to Dr. David Callejo for his theoretical guidance and valuable comments in different areas of this work. Without $\mathrm{Dr}$. Callejo's patience and commitment, the termination of this dissertation would not have been achieved.

I would also like to thank Dr. Ahmed Fakhri, from the Foreign Language Department, for his guidance, suggestions and support. His thoughtful comments and suggestions have helped me to properly form this research. I was very lucky that the first class I attended at West Virginia University was with him. He 
had a great impact on the way that I look at the educational and teaching acts. Thank you, Dr. Ahmed.

A special word of appreciation for Dr. Ernest Goeres for his help and cooperation. His valuable comments and suggestions have greatly improved the quality of this project. Throughout the course of this project, $\mathrm{Dr}$. Goeres' suggestions and comments were invaluable in finalizing the research and writing the dissertation. I appreciate the sincerity and interest with which he approached the research and realize that without his input, the project would not have been as clear, concise, or organized.

I wish to thank my friends Salem Abdulrahman Al Balwi and Charles Joukhadar for their encouragement and support. Special thanks to my friend Ali Al Qhahtani for his help and suggestion. Acknowledgement must be made to $\mathrm{Dr}$. Sebastian Diaz for his cooperation and commitment in the statistical methodology of this dissertation.

My grateful thanks to my fellow doctoral student William White for his encouragement and help. I have learned different things about the field of education from him. Throughout our conversations, discussions, and projects, I have learned much from him particularly in the American educational system. He really made my study journey in the United States very enjoyable. Thanks Bill. 
Many people have participated in completion of this research in Saudi Arabia. I would like to thank Haytham Bakri, from the IPA men's campus in Riyadh, Ibrahim Al Shaabi from the IPA men's campus in Jeddah, and Mahmoud Hamid from the IPA men's campus in Dammam. A special thanks also goes to Mrs. Norah Al Fayez, the director general of the IPA women's campus in Riyadh for her help and cooperation. 
xiii

\section{DEDICATION}

To mom and to the soul of my dad 


\section{CHAPTER ONE: INTRODUCTION}

In the past several years, a great deal of research has been conducted in the effectiveness and use of Computer-Assisted Language Learning (CALL), an offshoot of Computer-Assisted Instruction (CAI). During this time, the focus of the research has changed from what computers could offer language learners to how computers can best be used to facilitate language teaching. Chapelle (2001) stated:

Various forms of this question-whether or not computers should be used for language teaching-were echoed throughout the following decade, but during the 1990s the question gradually change from 'Should the computer be used for second language teaching?' to 'How can the computer best be used in language teaching. (p. 1)

Many studies, especially those conducted in Saudi Arabia, focus on the effectiveness of CALL and on teachers' perceptions toward the use of computers in language classrooms. Few studies, if any, focus specifically on student attitudes toward CALL. That is to say, how students perceive the use of computers in language learning. 
Because of the globalization of markets and technological advancements, English has increasingly become the lingua franca of the world. Saudi Arabia is no exception. Besides being the only required language for the foreign language requirement in higher education institutions, English is also a medium of instruction in many Saudi Arabian institutions of higher education, especially in institutions that concentrate on scientific and business related majors (medicine, nursing, pharmacy, computer science, engineering, economics, business administration, etc). The Institute of Public Administration (IPA), a Saudi government affiliated training school, uses English as a medium of instruction in one of its main two programs.

Like many higher education schools in Saudi Arabia, the IPA decided, in 2002, to integrate CALL into its one year intensive English program. As a pioneering institution in the use of CALL, the IPA chose to incorporate computers to help learners achieve a higher level of English language proficiency. Four years following the introduction of CALL into the IPA intensive English program, no studies have been conducted to determine the learner attitudes toward the use of CALL, teacher perceptions toward CALL, or the effectiveness of CALL.

The purpose of this study was to investigate the IPA learners' attitudes toward the use of CALL at the IPA. 
Understanding learner attitudes will help the IPA better understand learner needs and make decisions about the use of computers in their intensive English language program.

\section{Background}

Opened in 1961, the Institute of Public Administration (IPA) is a Saudi government affiliated institute that offers training sessions to government employees and associate degrees in different programs, including computer programming, computer networking, banking, hospital management, information system, statistics, sales, accounting, and hotel management to saudi high school graduates. Most of these associate degree programs are dedicated for both the public and the growing private sector. The IPA also offers a graduate certificate to university graduates in marketing, hotel management, and law studies.

The IPA has four campuses in Saudi Arabia: the main men's campus (called the Main Center in Riyadh) and women's campus (called Woman Branch) are in Riyadh, the capital of Saudi Arabia. One men's campus is located in Dammam on the east coast (called the Eastern Province Branch), and the other men's campus is located in Jeddah on the west coast of Saudi Arabia (called Makkah Province Branch). 
As stated above, there is only one IPA woman campus in Saudi Arabia, undoubtedly raising the question of why there is only one IPA women's campus compared to three IPA men's campuses? There are several reasons behind this situation. One of these reasons is that Saudi society is grounded on Islam. Therefore, the majority of the Saudi women go to universities or teacher colleges to be teachers teaching women in the segregated education system. The majority of Saudis believe that teaching in the segregated education in Saudi Arabia is the most proper job for women that fits the religious and cultural customs. Religious and cultural customs in Saudi Arabia refuse the gender mixed work environments. This notion of belief has changed dramatically, but just in last few years due to many factors. One factor is that the population of Saudi Arabia has increased rapidly in the last decades leading to an increase in the number of graduate women teachers. This makes getting a teaching position for women in schools very competitive, particularly, in religious and social subjects. The other factor is that there are many other jobs today that do not require working with men or having direct connection with males, for example, women bank branches, female sections in hospitals, etc. Again, these changes have taken place in less than a decade. The IPA administration is considering opening new women branches and expand the capacity of the only women's campus in Riyadh. 
IPA has two training programs. The first one for the government employees is called Training Programs (TPs). The training programs consist of short training sessions, seminars, applied seminars, discussions, computer literacy, and skill practice. The aim of TPs is to increase the government staff efficiency and provide them with needed experiences and skills. Thousands of government employees from different ranks and agencies join these different training sessions every year. After completing the training, those employees earn certificates that help them get promoting or get better job either inside or outside their government affiliations. Arabic is the dominant medium of instruction in TPs. However, English is used frequently in some TPs.

The second type of training that IPA offers is Preparing Programs (PPs). The PPs are mostly for the high school graduates to prepare Saudi skilled labor "blue-collar labor" for both the public and the growing private sectors. The main goal behind the PPs is to reduce the country's dependence on expatriate labor. The number of foreigners in Saudi Arabia is around 6 million which represents a quarter of the population of the country. The PPs offer associate diplomas for high school graduates in computer programming, computer networking, banking, hospital management, information system, statistics, sales, accounting, and hotel management. They also offer graduate 
certificates for university graduates in marketing, hotel management, and law studies.

High school graduates from all over the Kingdom of Saudi Arabia join the PPs at IPA campuses every year. The choice of IPA campus by learners depends mainly on the type of program learners desire and how far it is from learner's hometown. Most of those learners end up in both public and private sector, and a small proportion of students pursue their higher education.

The IPA offers PP learners stipends and free dormitory housing. English is the only medium of instruction in all the PPs .

Students who want to join these programs need to pass a computerized admission test. This test consists of general information questions and qualifying exam in English. The general information questions test the learner general knowledge in Arabic, mathematics, logic, and other related information. The qualifying English exam tests the learners' English skills in grammar, vocabulary, and writing. After passing the admission exam, the students also complete one year in the English language program. This program is divided into four levels (see Table 1.1): preparatory, elementary, intermediate, and advanced. Each level lasts 8 weeks. Some of these levels could be waived for those who achieve high scores in an optional English placement test that IPA offers for accepted learners. 
Table 1.1 English Language Levels at IPA

\begin{tabular}{|c|c|c|c|c|c|}
\hline \multicolumn{6}{|c|}{ One Year English Language Program } \\
\hline Level & Preparatory & \multicolumn{2}{|c|}{ Elementary } & Intermediate & Advanced \\
\hline Duration & 8 weeks & $8 \mathrm{n}$ & & 8 weeks & 8 weeks \\
\hline Focus & \multicolumn{3}{|c|}{ General English } & \multicolumn{2}{|c|}{ English for Specific Purposes } \\
\hline Skill & Reading & iting & Oral & Listening & Grammar \\
\hline
\end{tabular}

Learners divide these 24 hours of weekly study between five language skills: reading, writing, oral, listening, and grammar (see Table 1.2). The IPA students study general English skills during the first two levels (preparatory and elementary). In the intermediate and advanced levels, students learn English for specific purposes based on their majors. For example, the focus in the last two levels will be on medical terms and language used in the hospital context for hospital management majors, whereas the concentration in intermediate and advanced levels for computer majored students is on technical terms and computer register language.

Table 1.2 IPA Intensive English Program Descriptions

\begin{tabular}{|c|c|}
\hline Skill & Hours per Week \\
\hline Reading & 5 \\
\hline Writing & 5 \\
\hline Oral & 5 \\
\hline Listening & 3 \\
\hline Grammar & 6 \\
\hline Total & 24 \\
\hline
\end{tabular}


While the communicative approach to language teaching is the primary teaching method, the IPA uses other methods of teaching. The eclectic approach ensures that learners achieve a high proficiency of English, enabling them to enter the growing private sector.

In 2002, the IPA decided to integrate the use of computers in teaching English in all four campuses to enhance learners' proficiency by employing technology in language teaching and optimize the benefits of technology for language teaching and learning. Today, each IPA campus has CALL labs (see Table 1.3). A second less publicized reason was to meet the shortage of English language instructors, particularly the native ones.

Table 1.3 CALL labs at IPA campuses

\begin{tabular}{|c|c|c|c|c|}
\hline IPA campus & $\begin{array}{c}\text { Main campus } \\
\text { Riyadh }\end{array}$ & Woman Branch & Dammam Branch & Jeddah Branch \\
\hline $\begin{array}{c}\text { Number of } \\
\text { CALL lab }\end{array}$ & 8 & 2 & 2 & 2 \\
\hline $\begin{array}{c}\text { Number of } \\
\text { Computers }\end{array}$ & 25 & 25 & 25 & 25 \\
\hline
\end{tabular}

EFL learners spend 6 hours weekly (see Table 1.4) between the five skills they study: reading, writing, oral, listening, and grammar. However, the majority of these 6 hours are dominated by grammar teaching. 
Table 1.4 CALL labs hours at IPA

\begin{tabular}{|c|c|}
\hline Skill & CALL lab hours \\
\hline Reading & 1 \\
\hline Writing & 1 \\
\hline Oral & 1 \\
\hline Listening & 1 \\
\hline Grammar & 2 \\
\hline
\end{tabular}

The software used in the CALL labs at the IPA is New Dynamic English (known as DynEd). DynEd consists of four language levels and each level has two modules and two disks (see Table 1.5). Each disk has different activities that require learners to practice different skills. The $1^{\text {st }}$ level is for beginner, the $2^{\text {nd }}$ level for low intermediate level learners, the $3^{\text {rd }}$ is for intermediate, and finally the $4^{\text {th }}$ is for upperintermediate and advanced level students (Fitzgeral, Bower, \& Morrall, 1999)

Table 1.5 New Dynamic English Models

\begin{tabular}{|c|c|c|c|}
\hline $\begin{array}{c}\text { Modules } 1 \& 2 \\
\text { Activities }\end{array}$ & $\begin{array}{c}\text { Modules } 3 \& 4 \\
\text { Activities }\end{array}$ & $\begin{array}{c}\text { Modules } 5 \text { \& } 6 \\
\text { Activities }\end{array}$ & $\begin{array}{c}\text { Modules } 7 \& 88 \\
\text { Activities }\end{array}$ \\
\hline $\begin{array}{l}\text { Names \& Places } \\
\text { Jobs \& Family } \\
\text { Numbers \& Time } \\
\text { Review Exercises } \\
\text { Video } \\
\text { Interactions } \\
\text { Family Schedule } \\
\text { Matrix } \\
\text { Vocabulary } \\
\text { Likes \& Dislikes } \\
\text { Review Exercises } \\
\text { Video } \\
\text { Interactions }\end{array}$ & $\begin{array}{l}\text { Daily Activities } \\
\text { Our World } \\
\text { Locations } \\
\text { Review Exercises } \\
\text { Video Interactions } \\
\text { Planning Ahead } \\
\text { Matrix Vocabulary } \\
\text { Biography } \\
\text { Review Exercises } \\
\text { Video Interactions }\end{array}$ & $\begin{array}{l}\text { On a Trip } \\
\text { Energy Sources } \\
\text { Directions } \\
\text { Review Exercises } \\
\text { Video Interactions } \\
\text { Life Experiences } \\
\text { Matrix Vocabulary } \\
\text { Comparisons } \\
\text { Review Exercises } \\
\text { Video Interactions }\end{array}$ & $\begin{array}{l}\text { Life Choices } \\
\text { Epidemic } \\
\text { Space \& Time } \\
\text { Sequences } \\
\text { Review Exercises } \\
\text { Video Interactions } \\
\text { The Secret Code } \\
\text { Mystery } \\
\text { Matrix Vocabulary } \\
\text { UFOs: For \& Against } \\
\text { Review Exercises } \\
\text { Video Interactions }\end{array}$ \\
\hline
\end{tabular}

Table Adapted from New Dynamic English Website 


\section{Purpose of the Study}

The purpose of the study was to identify the IPA Saudi EFL learners' attitudes toward the use of computers in their English language program. Specifically, the areas to be addressed are their attitudes toward CALL, their attitudes toward the CALL software, and the effect of years of English study, computer knowledge, and gender differences on these attitudes (see Figure 1.1). Descriptive information gathered from students including gender, academic field, English language background, age, and the current level of English language study.

Figure 1.1 Demographic Variables Affect the Learners' Attitudes toward CALL

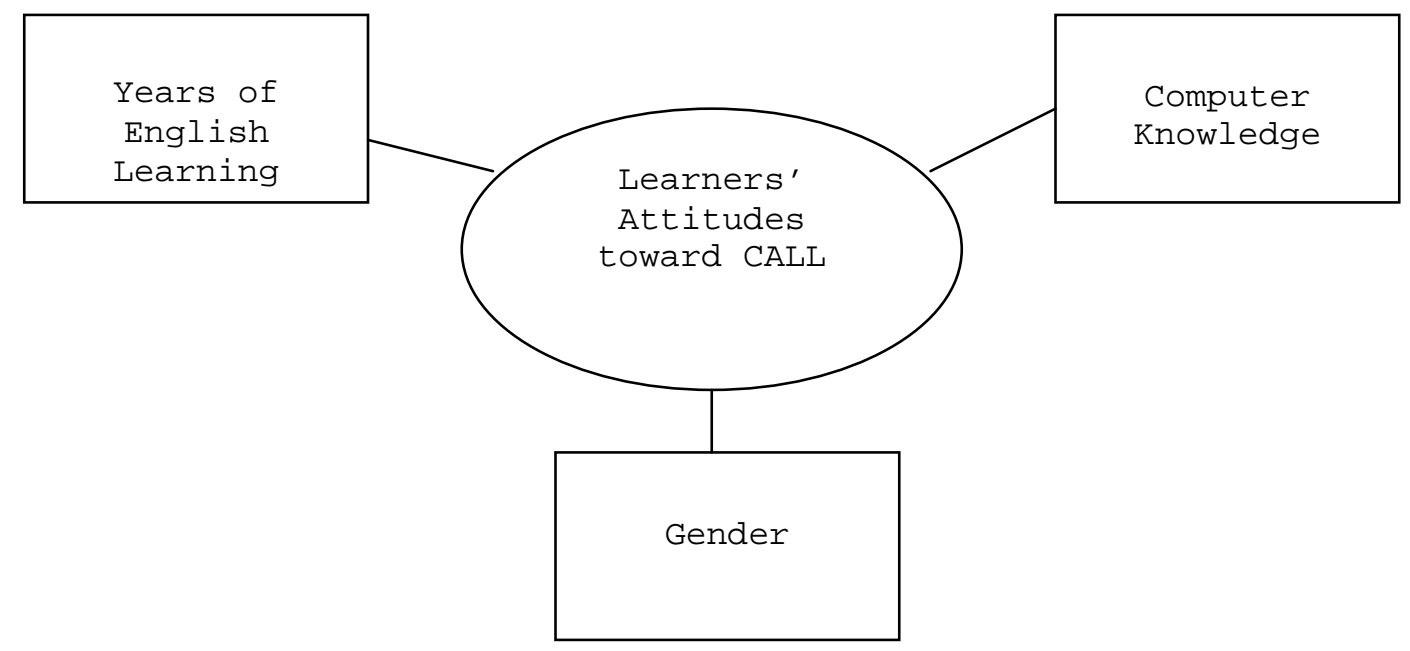




\section{Research Questions}

The primary research agenda for this study is to examine, describe, and explore IPA learners' attitudes toward the use of CALL in the IPA intensive English program. Specifically, the study addressed the following research questions:

Research question 1: What are the Saudi EFL learners' attitudes toward CALL in general at the IPA?

Research question 2: What are Saudi EFL learners' attitudes toward the CALL software used at the IPA?

Research question 3: What are the differences between Saudi EFL learners' attitudes toward CALL at the IPA based on their years of English learning?

Research question 4: What are the differences between Saudi EFL learners' attitudes toward CALL at the IPA based on their computer knowledge?

Research question 5: What are the differences between Saudi EFL learners' attitudes toward CALL at the IPA based on their gender?

\section{Significance of the Study}

The importance of understanding learner attitudes toward language learning, of which CALL is an important subfield, has been noted by several researchers (Gardner \& Lambert 1972; Savignon, 1976; Krashen, 1985). Yet very little, if any, 
research has been conducted on student attitudes toward CALL in Saudi Arabia. Some previous studies (Al-Juhani, 1991; Walker, 1994; Al Kahtani, 2001; Abalhassan, 2002; Alrumaih, 2004) in Saudi Arabia treated the effectiveness of the use of computers in language learning and teachers' perceptions of and attitudes toward CALL. Therefore, this study is important for properly identifying Saudi English as a Foreign Language (EFL) learners' attitudes toward CALL. The findings of this research project will assist the IPA administration in formulating appropriate goals and understanding how IPA students perceive the integration of computers in their English study. Better decisions will be made upon a more complete understanding of the IPA Saudi EFL learners' attitudes toward CALL.

The study will also provide information to other EFL programs, both private and public, in Saudi Arabia to devise and reformulate CALL components of their English language programs.

\section{Limitation of the Study}

The findings of this study maybe limited by the following:

1. No previous studies on the attitudes of Saudi learners toward CALL in EFL programs have been conducted. As such, no research guidelines or questions were available to use as a point of departure or comparison in this study; 
2. Students studying at IPA which makes it less generalizable to the entire Saudi context;

3. Current IPA's students;

4. Three independent variables, a) years of English learning, b) computer knowledge, and c)gender; and

5. Students engaged in IPA intensive English program (not including those who get short training sessions)

\section{Organization of the Study}

This dissertation consists of five chapters. The First Chapter contains the introduction, background, statement of purpose, research questions, significance of study, limitations of the study, and the organization of the study. Chapter Two provides a review of literature related to computer use in language learning and attitudes. Chapter Three deals with the methodology used to conduct the study. Chapter Four contains the results and analysis of the study. Finally, Chapter Five contains the discussion of the findings and the recommendations.

Operational Definitions

For the purpose of the study, the following terms will be defined according to their usage in the study. 
EFL: is an acronym for English as a Foreign Language. EFL means to study English in a country that English is not the native, primary, or national language of that country.

Learners: are Saudi undergraduate students who learn English as a foreign language at the Institute of Public Administration in Saudi Arabia.

CALL: is an acronym stands for Computer-Assisted Language Learning. The defining of CALL is a controversial issue. CALL in this study is defined as the use of computers in teaching English as a foreign language at the English intensive program in the Institute of Public Administration in Saudi Arabia.

Computer knowledge: The computer knowledge of learners in this study is defined by the combination of ownership of computers, years of computer experience, hours of daily use, and self-evaluation of computer experience.

Attitude: The definition of Palaigeorgiou et al. (2005) stating that attitudes is "a positive or negative sentiment, or mental state, that is learned and organized through experience and that exercises a discrete influence on the affective and conative responses of an individual toward some other individual, object or event" (p. 39) will be used as the definition of attitudes.

Attitudes toward Computers: Smith et al. (2000) defined attitudes toward computers as "a person's general evaluation or 
feeling of favourableness or unfavourableness toward computer technologies (i.e. attitude toward objects) and specific computer-related activities (i.e. attitudes toward behavior" ( $p$. 61). The study will use this definition in defining attitudes toward computers. 


\section{CHAPTER TWO: LITERATURE REVIEW}

The specific topic of the study is to investigate the Saudi EFL learners' attitudes toward CALL. The main issues of the study are CALL and attitudes of learners. Literature on the definition of CALL, the historical context of CALL, the CALL development, and the CALL applications will be given in the first part of this chapter. The second part of this chapter will concentrate on attitudes. The literature review of attitudes will consider the concepts of attitudes, attitudes and language learning, and attitude towards computers use in instruction. The literature review is necessary to provide the reader a clear idea about the study.

\section{Defining CALL}

CALL is a relatively new field in language learning. It is an interdisciplinary field of study (see Figure 2.1) that interacts with other disciplines: Language Learning; Computer Science; Psychology; Artificial Intelligence; Instructional Technology and Design; and Computational Linguistics (Levy, 1997). All the aforementioned fields have contributed in forming CALL and moved CALL from one stage to another, making it a field of immense change and transition (Iandoli, 1990). CALL 
emerged as a part of Computer-Assisted Instruction (CAI), "the use of computers as a tool of instruction according to group and individual needs" (Hertz, 1987, p. 1). CAI is one application of Artificial Intelligent (AI) and AI according to Coughlin (1990) "attempts to make computers perform cognitive tasks in all areas of human endeavor" (p. 561).

Figure 2.1 CALL and the Related Fields

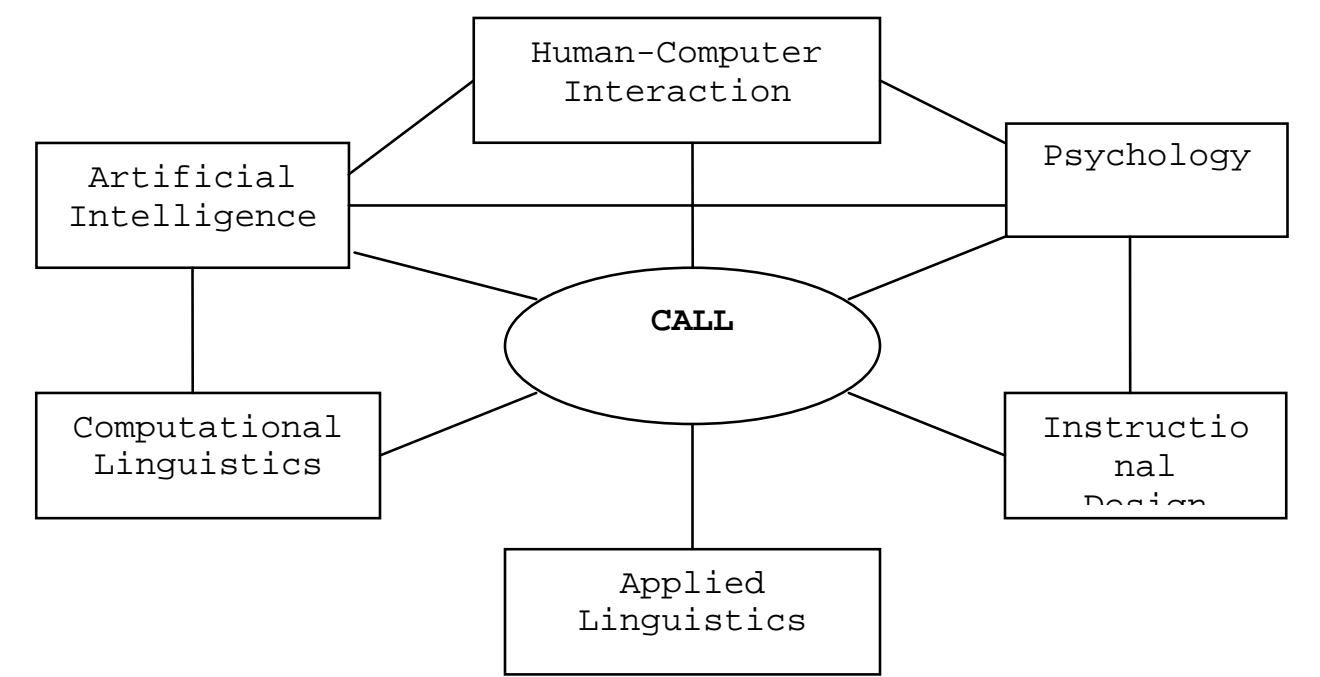

Figure Adapted from Levy (1997)

The precise definition of CALL is an issue that has been debated since the birth of the field. The term CALL is controversial when the use and development of technology in language learning or teaching is discussed. Today, different terms indicate technology involvement in language learning and teaching: Computer-Assisted Learning (CAL); Computer-Assisted 
Language Instruction (CALI); Computer-Adaptive Testing (CAT); Computer-Mediated Communication (CMC); Intelligent Computerassisted Language Learning (ICALL); Technology Enhanced Language Learning (TELL); Web Enhanced Language Learning (WELL); Computer-application in Second Language Acquisition (CASLA); Computer-enhanced Language Learning (CELL); and Computer-based Language Testing (CBLT). Levy (2005) compares this issue, or what he calls "the competing terms" with a similar situation found in the fields of Second Language Acquisition and Applied Linguistics. Both Second Language Acquisition and Applied Linguistics refer to the use of language theories in language learning and teaching contexts. Chapelle (2001) revealed and admitted such disagreement on terms when carefully mentioning the term CALL in her book. Chapelle wrote:

Computer-assisted language learning (CALL) was the expression agreed upon at the 1983 TESOL convention in Toronto .............. I have retained this term throughout this volume to refer to the area of technology and second language teaching and learning despite the fact that revisions for the term are suggested regularly. (p. 3)

However, in her new book, Chapelle did not put the term CALL in the title. Instead she called it "English Language 
Learning and Technology" although the contents of her book are all on CALL (Levy, 2005). Egbert (2005) commented on this issue, writing that different terms are used by educators to describe CALL and to say that there is a need for exploring its boundaries and clarifying its components. She wrote that the most explanations of CALL are based on three categories: 1) "how learners use it (i.e. word processing); 2) the place where it is used (school, home, lab); and 3) the philosophy behind its constructions (Behavioristic, communicative, or integrative)" (p. 4).

Egbert (2005) believes that the conflict over the term "CALL" is justified. She points out that today computers are as important as the book and chalkboard, but no one uses the term book-enhanced language learning. This reminds us that the first time a book was used, it also caused a controversy and many thought that books would cause damage to human memory (Egbert, 2005). Only later they accepted the use of books and what we have now with computer is the same case. Hence, the acceptance of CALL as a new tool in language learning, similar to books, chalk, or the black board in classroom, would limit the argument over defining CALL (Egbert, 2005). Bax (2003) supported such a claim by saying that CALL has not reached the normalization level where it is considered an essential part of the classroom setting. 
Levy (2005) suggested that the term CALL should be the general label that encompasses all the uses of technology in language learning and teaching. His three main reasons were: "the distinctiveness and complexity of language as an object for learning, the de facto existence of a substantial, international group of individuals and established professional organizations that have continued to use the term for more that two decades" (p. 148).

Few researchers have set broad definitions that consider the current situation of the field and approximately try to cover all technology use in language learning. Egbert (2005) defines CALL as "using computer to support language teaching and learning in some way. This definition applies to all languages, skill areas, and contents"(p. 3). Beatty (2003) said that the notion of CALL has changed rapidly. Hence, she defines it as “any process in which a learner uses a computer and, as a result, improves his or her language" (p. 7). Levy (1997) defines CALL as "the search for and study of applications of the computer in language teaching and learning" (p. 1). It is obvious that all the three definitions encompass the three main words of the term "CALL": computer, language, and learning and make the use of technology represented by computer in language learning is united under one solid term. 


\section{Historical Background of CALL}

The literature of historical context of CALL does not show the exact time that computers were first used in language learning. The literature below reveals most of what have been said about the start of CALL and its historical developments. Fotos \& Browne (2004) believed that using computer in language came into existence from mechanical translation that was first used in the 1940s as a spin-off from cryptography used in World War II. Sokolik (2001) supported that by saying that the actual history of using computers in education goes back to the 1940s. CAI was first used in USA in the 1950s (Chapelle, 2001). Warschauer and Healey (1998) and Egbert, Jessup \& Valacich (1991) also wrote that computers have been used for language teaching since the 1950s, but that early computer applications in language teaching were very limited and difficult to use. The first documentation of computers in language was in the 1960s (Chapelle, 2001). In addition, access to the technology was not available except for a few teachers who maintained a good computer literacy at that time (Egbert et al., 1991). Educators started to visualize the potentiality of computers in classrooms in the decade that followed the advent of the first computer in the late 1940s (Dunkel, 1987). By the 1960s, linguists were using computers to analyze texts, and 
simple CALL programs actually arose as early as the 1950s (Fotos \& Browne, 2004).

Most of the early CALL projects were in the USA, used to teach, read, and translate Russian (Beatty, 2003; Ahmed, Corbett, \& Rogers, 1985). Atkinson (1965) wrote that teaching Russian was among early CAI uses. He stated that "In the Stanford project alone, approximately 4000 students are daily being processed in subjects ranging from initial reading and mathematics in the primary grades to college courses in Russian" (p. 589). Political reasons, particularly The Cold War, were the main reasons behind the idea of using computers in language learning and teaching. Beatty (2003) confirmed this by stating that:

in many projects, Cold war (1945-1991) political motivations may have been involved in funding, particularly those based on insecurities about the Union of Soviet Socialist Republics' (USSR) advances in science after the USSR's launch, on 4 0ctober 1975, of Sputnik. The first CALL programs were created at three pioneering institutions: Stanford University, Dartmouth University, and the University of Essex.... all focused on the teaching of Russian. (p. 17, 18) 
The early CALL project in United States was started as a part of a larger computer-Assisted Instruction (CAI) in the Institute for Mathematical Studies in the Social Science at Stanford University and was directed by Richard Atkinson and Patrick Suppes (Chapelle, 2001). This project came under the supervision of Van Campen in the Slavic Languages Department and was used for teaching an introductory Russian course (Taylor, 1980; Ahmed et al., 1985). Another early CALL project was the PLATO (Programmed Logic for Automatic Teaching Operations) system at the University of Illinois with cooperation with Control Data Corporation (Ahmed et al., 1985). Levy (1997) said that actual CALL began with PLATO. PLATO was designed also to teach Russian using the grammar translation method of teaching (Levy, 1997; Betty, 2003). The work at Dartmouth College in New Hampshire was also among early CALL projects that language teachers used in 1970 and covered Danish, French, Latin, German, and Spanish (Ahmed et al., 1985). The only early CALL project outside USA was The Scientific Language Project at University of Essex in UK, designed to help in reading Russian texts (Ahmed et al., 1985).

The high cost of hardware in the past delayed the use of computers in classrooms (Dunkel, 1987). Dunkel (1987) wrote that "In the past, high initial capital investment for hardware made implementation of CAI prohibitive" (p. 251). In the 1960s, 
the first computer "EDVAC" cost approximately $\$ 700,000$ to produce, but twenty years later, the cost of a Model 30 computer was $\$ 280,000$ (Dunkel, 1987). The high cost and use for pure research of early computer machines meant that time dedicated for learning and teaching was limited (Beatty, 2003). The later development of technology has moved CALL forward to be more sophisticated and effective as an arena for language learning.

\section{Development of CALL}

The history of computers in language learning is divided into three stages (see Table 2.1) (Kern \& Warschauer, 2000; Warschauer, 1996).

Table 2.1 The Three stages of CALL according to Warschauer's model

\begin{tabular}{|c|c|c|c|}
\hline Stage & $\begin{array}{c}\text { 1970s-1980s: } \\
\text { Structural CALL }\end{array}$ & $\begin{array}{c}\text { 1980s-1990s: } \\
\text { Communicative } \\
\text { CALL }\end{array}$ & $\begin{array}{c}\text { 21 } \\
\text { Integrative CALL }\end{array}$ \\
\hline $\begin{array}{c}\text { Mechnology } \\
\text { Mainframe } \\
\text { Paradigm }\end{array}$ & $\begin{array}{c}\text { Grammar- } \\
\text { Translation \& } \\
\text { Audio-Lingual }\end{array}$ & $\begin{array}{c}\text { Communicative } \\
\text { Language } \\
\text { Teaching }\end{array}$ & $\begin{array}{c}\text { Multimedia and } \\
\text { Internet }\end{array}$ \\
\hline $\begin{array}{c}\text { View of Language } \\
\text { ESP/EAP }\end{array}$ \\
\hline $\begin{array}{c}\text { Structural (a } \\
\text { formal } \\
\text { structural } \\
\text { system) }\end{array}$ & $\begin{array}{c}\text { Cognitive (a } \\
\text { mentally- } \\
\text { constructed } \\
\text { system) }\end{array}$ & $\begin{array}{c}\text { Socio-cognitive } \\
\text { (developed in } \\
\text { social } \\
\text { interaction) }\end{array}$ \\
\hline $\begin{array}{c}\text { Drill and } \\
\text { Practice } \\
\text { Objective }\end{array}$ & $\begin{array}{c}\text { Communicative } \\
\text { Exercises }\end{array}$ & $\begin{array}{c}\text { Authentic } \\
\text { Discourse }\end{array}$ \\
\hline
\end{tabular}

Table Adapted from Warschauer (2004) 
The first stage of CALL, called Behavioristic or Structural (Warschauer, 2004) CALL, was conceived in the 1950s and implemented in a decade later (Warschauer, 1996). This stage of CALL was influenced by the dominant psychological theory of learning of the 1950 s and 1960s which saw language learning similar to other kinds of learning involving habit formation or stimulus-response connections (Ellis, 1997). Hence, it follows the Behaviorist instructional design (see Figure 2.1).

Figure 2.1 The Behaviorist Instructional Design

- Eliminate extraneous information

- Simplifies for comprehensibility

- Uses a convergent, task-analyzed model as a basis

- Focuses on acquiring skills

- Offers prescriptive sequences of instruction

- Supports individual learning and competition

Figure Adapted from Betty (2003)

Behavioristic CALL was based on a belief that computers can play the role of a tutor that provides drill and practice exercises (Taylor, 1980). CALL at that time, was supported by mainframe computers which were connected to terminals by telephone lines or on a single campus to terminals off campus (Chapelle, 2001). Programs in this phase contained repetitive language drills and were referred to as "drill and practice". They consisted of grammar and vocabulary practice. The Audio- 
lingual method and structural linguistics were the teaching techniques in Behavioristic CALL (Fotos \& Brown, 2004). Computers in Behavioristic CALL were the vehicle for giving instructional material to learners, in order to provide corrective feedback to learners on their responses until they had mastered correct forms. A good example of Behavioristic CALL is the PLATO, which was primarily used for teaching Russian, translating Russian documents into English, especially scientific documents, brief grammar instruction, and vocabulary drilling (Ahmed et al., 1985). Early programs were linear and learners had to go through the same steps in the same style, and the tasks were basically adopted from exercises from books (Beatty, 2003). Warschauer (1996) stated that the undermining of Behavioristic CALL was due to two reasons: (1) the theoretical and pedagogical rejection of Behavioristic Approaches to Second Language Acquisition, and (2) the advent of microcomputers or Personal Computers (PC). Fotos \& Browne (2004) added that the decline of Behavioristic CALL was due to the challenges by the communicative approaches in language learning that goes beyond focusing on formal instruction, but rather on meaning focused language. All these reasons opened the door for a new phase of CALL, entitled of Communicative CALL . 
Communicative CALL, first used in the 1970s (Fotos \& Browne, 2004), is based on the communicative approach in language teaching that took hold at that time (Richards \& Rogers, 2001). The communicative approach in language teaching emerged from the theory of language as communication, and the aim of language teaching is to develop the learners' communicative competence (Richards \& Rodgers, 2001). Lee and VanPatten (2003) explained the role of students in communicative approach that "the students' task was no longer to parrot but to create an answer" (p. 11). Fotos \& Browne (2004) explained the goal of Communicative CALL as a "communicative use of the language rather than mastery of isolated forms" (p. 5).

Communicative CALL also followed the cognitive view of language acquisition (Warschauer, 2004), defined by Fotos \& Browne as a method "that aimed to stimulate students' motivation, critical thinking, creativity, and analytical skills rather than merely the achievement of a correct answer or the passive comprehension of meaning" $(p .6)$. The model of this stage, in addition to "computer as tutor", is also "computer as stimulus" and "computer as workhorse" (Taylor \& Perez, 1989). The computer in Communicative CALL was considered a stimulus that enhances learner's motivation (Taylor \& Perez, 1989). Warschauer (1996) wrote that the aim of communicative CALL was to focus on using forms rather than on the forms themselves. 
For example, the goal was to teach grammar implicitly rather that explicitly and to allow learners to make original utterances (Underwood, 1984 in Warschauer \& Healey, 1998).

By the end of the 1980s, language educators felt that CALL had failed to give learners what they thought, and researchers showed that computers were being used in an ad hoc and disconnected fashion (Warschauer, 1996). Coughlin (1990) called the late seventies CALL programs a little more that an imitation of their predecessors, the audiolingual tapes, and that programs followed the drill-based methods and emphasized correct grammar use. Warschauer (1996) pointed out that the critiques of communicative CALL were also linked with the reassessment of the communicative approach in language teaching field. Critiques of the communicative approach to the Second Language Acquisition in addition to the technological developments in the multimedia opened the door for a new phase of CALL, labeled Integrative CALL .

Integrative CALL is the present stage of CALL (Warschauer, 1996; Warschauer, 2004). It has been used since the mid of $1990 \mathrm{~s}$ (Fotos \& Browne, 2004). It is based on the Vygotsky's sociocultural model of language learning (Wertsch, 1985 cited in Fotos \& Browne, 2004). Vygotsky's cognitive model, or sociocultural model, stated that the way we think is a formation of both cultural and social influence (Snowman \& Biehler, 2006). 
Snowman \& Biehler (2006) said that the ideas of Vygotsky could be applied in educational technology in two ways: first, by using the computer as an expert to provide necessary skills and strategies which can be internalized by students, and second, by using the computer as a tool that connects students to more knowledgeable counterparts and experts who "establish a masternovice apprenticeship and scaffold the student's learning" ( $p$. $52)$.

The Integrative approaches of CALL have benefited from multimedia (Warschauer, 1996). Multimedia is a format of communication that integrates many types of media like graphics, animation, sound, images, text, and video (Snowmand \& Biehler, 2006). It is represented today by the CD-ROM. Multimedia has been more effective by entailing the hypermedia (Warschauer, 1996). Snowman and Biehler (2006) said: "Hypermedia is the marriage of multimedia and hypertext" (p. 114). Hypertext is a system that links texts in a nonlinear way enabling users to move from one part of text to another within the same document or to other documents. This process often takes place through highlighted words (Snowman \& Biehler, 2006). Multimedia application could create a more real world and authentic learning environment for learners; integrate all language skills (since the media combine reading, writing, listening and speaking) in a single activity; give students more control over 
how they learn; and make them focus on the content, not on the language form or the learning strategies (Warschauer, 1996). Hypermedia allowed CALL to be highly interactive and provide learners with authentic situations where they unprecedentedly are able to interacts with native speakers of the language they study (Coughlin, 1990). Warschauer and Healey (1998) said that Integrative CALL can offer realistic environments of the language, a curriculum for language learning, assessments, determine the appropriate next step for the learner, and keep records of learners. Szendeffy (2005) lists some features of Integrative CALL like using of authentic environments; integrating of all skills in a holistic approach; using multimedia and hypermedia in a nonlinear manner; offering greater student control; giving task-based, content-based, and project-based activities; and communicating with native speakers and other learners. The model of Integrative CALL is also based on socio-cognitive view of the language, which according to Warschauer (2004) means that learning a second or foreign language involves working one's way into new discourse communities.

Although Warschauer' model is common in CALL literature, Bax (2003) argued that such a model has weaknesses. For example, Warschauer used different names for the first stage "Behavioristic" (Warschauer, 1996; Warschauer \& Healey, 1998) 
and then changed it to "Structural" (Warschauer, 2004). Bax (2003) also showed that the dates were different in different publications. He also mentioned that stating the decline of Communicative CALL causes a great confusion for teachers since not only Communicative CALL, but all the three types of CALL are still in used in different institutions. Thus, he offered an alternative model of CALL. Bax (2003) believes that we should use the term "approaches" instead of "stages" since the term "stage" strictly refers to history whereas the term "approach" covers other aspects as well. His alternative model divided CALL into three approaches: Restricted CALL, Open CALL, and Integrated CALL (see Table 2.2). For the first approach, Restricted CALL, Bax (2003) said that the term "Restricted" goes beyond, for example, the theory of learning. It is comprehensive, more flexible, and covers the teacher's role in this approach which is believed to be restricted to monitoring and the feedback restricted to closed responses. He said that Restricted CALL dominated before the 1980s.

Open CALL indicates the use of CALL from the 1980s until now. His rationale for calling it open CALL indicates that attitudes toward using computers were more open and becoming more humanistic. Open CALL, according to Bax (2003), is the recent phase of CALL, but this does not mean that all institutes are not using Restricted CALL. He said that "we could argue 
that in general terms we are in an open phase of CALL, but that each institution and classroom may also exhibit certain Restricted and even Integrated features" (p. 23).

The third approach of CALL is called Integrated CALL (Bax, 2003). Bax (2003) believes that we have not yet reach of this stage of CALL, since CALL, unlike books and pens in language teaching, is not invisible. Bax (2003) called this concept "normalization", which has relevancy to any types of technological innovations and refers to the stage when the use of technology becomes invisible and consequently normalized. 
Table 2.2. Bax's model of CALL

\begin{tabular}{|c|c|c|c|c|c|c|c|c|}
\hline Content & Type of Task & $\begin{array}{l}\text { Type of } \\
\text { Student } \\
\text { Activity }\end{array}$ & Type of Feedback & $\begin{array}{l}\text { Teacher } \\
\text { Role }\end{array}$ & $\begin{array}{l}\text { Teacher } \\
\text { Attitude }\end{array}$ & $\begin{array}{l}\text { Position in } \\
\text { Curriculum }\end{array}$ & $\begin{array}{l}\text { Position } \\
\text { in Lesson }\end{array}$ & $\begin{array}{l}\text { Physical } \\
\text { Position } \\
\text { of } \\
\text { Computer }\end{array}$ \\
\hline $\begin{array}{l}\text { Restricted } \\
\text { CALL } \\
\text { Language } \\
\text { System }\end{array}$ & $\begin{array}{l}\text { Closed drills } \\
/ \\
\text { Quizzes }\end{array}$ & $\begin{array}{l}\text { Text } \\
\text { reconstruction } \\
\\
\text { Answering } \\
\text { closed } \\
\text { questions } \\
\text { Minimal } \\
\text { Interaction } \\
\text { with other } \\
\text { students }\end{array}$ & Correct/incorrect & Monitor & $\begin{array}{l}\text { Exaggerated } \\
\text { fear and/ } \\
\text { or awe }\end{array}$ & $\begin{array}{l}\text { Not } \\
\text { integrated } \\
\text { into } \\
\text { syllabus and } \\
\text { learner } \\
\text { needs }\end{array}$ & $\begin{array}{l}\text { Whole } \\
\text { CALL } \\
\text { lesson }\end{array}$ & $\begin{array}{c}\text { Separate } \\
\text { computer } \\
\text { lab }\end{array}$ \\
\hline $\begin{array}{l}\text { Open CALL } \\
\text { system and } \\
\text { Skills }\end{array}$ & $\begin{array}{l}\text { Simulations } \\
\text { Games/ } \\
\text { CMC }\end{array}$ & $\begin{array}{l}\text { Interacting } \\
\text { with the } \\
\text { computer } \\
\text { Occasional } \\
\text { interaction } \\
\text { with other } \\
\text { students }\end{array}$ & $\begin{array}{l}\text { Focus on } \\
\text { linguistic skills } \\
\text { development } \\
\text { Open, flexible }\end{array}$ & $\begin{array}{l}\text { Monitor/ } \\
\text { facilitator }\end{array}$ & $\begin{array}{l}\text { Exaggerated } \\
\text { fear and } \\
\text { /or awe }\end{array}$ & $\begin{array}{l}\text { Toy Not } \\
\text { integrated } \\
\text { into } \\
\text { syllabus- } \\
\text { optional } \\
\text { extra } \\
\text { Technology } \\
\text { precedes } \\
\text { syllabus and } \\
\text { learner } \\
\text { needs }\end{array}$ & $\begin{array}{l}\text { Whole } \\
\text { CALL } \\
\text { lesson }\end{array}$ & $\begin{array}{l}\text { Separated } \\
\text { lab-perhaps } \\
\text { devoted to } \\
\text { languages }\end{array}$ \\
\hline $\begin{array}{l}\text { Integrated } \\
\text { CALL } \\
\text { Integrated } \\
\text { language } \\
\text { skills work }\end{array}$ & $\begin{array}{l}\text { CMC/ } \\
\text { WP/ } \\
\text { e-mail/ } \\
\text { As any } \\
\text { appropriate } \\
\text { to the } \\
\text { immediate } \\
\text { needs }\end{array}$ & $\begin{array}{l}\text { Frequent } \\
\text { interaction } \\
\text { with other } \\
\text { students } \\
\text { Some } \\
\text { interaction } \\
\text { with computer } \\
\text { through the } \\
\text { lesson }\end{array}$ & $\begin{array}{l}\text { Interpreting, } \\
\text { evaluating, } \\
\text { commenting, } \\
\text { simulating } \\
\text { thought }\end{array}$ & $\begin{array}{l}\text { Facilitator } \\
\text { Manager }\end{array}$ & $\begin{array}{l}\text { Normal part } \\
\text { of } \\
\text { teaching- } \\
\text { normalized }\end{array}$ & $\begin{array}{l}\text { Tool for } \\
\text { learning } \\
\text { Normalized, } \\
\text { integrated } \\
\text { into } \\
\text { syllabus, } \\
\text { adapted to } \\
\text { learners' } \\
\text { needs } \\
\text { Analysis of } \\
\text { needs and } \\
\text { context } \\
\text { precedes } \\
\text { decisions } \\
\text { about } \\
\text { technology }\end{array}$ & $\begin{array}{l}\text { smaller } \\
\text { part of } \\
\text { every } \\
\text { lesson }\end{array}$ & $\begin{array}{l}\text { In every } \\
\text { classroom, } \\
\text { on ever } \\
\text { desk, in } \\
\text { every bag }\end{array}$ \\
\hline
\end{tabular}




\section{Applications of CALL}

Computers in learning can be used in different ways. Taylor (1980) said that computers in learning are used in three different methods: computers as a tutor, computers as a tool, and computers as a tutee. Computers as a tutor mean that students get tutoring from the computer. For example, the computer provides material, gets the students' responses, assesses that responses, then decide what to present next based on the learners' responses (Taylor, 1980). Using computers as a tool means that students seek helps from computers in different subjects. For example, students use computers as word processor. Using computers as tutee refers to the process in which the student or the teacher gives the computer some information or talk in a language that the computer understands. Warschauer (1996) divided CALL typology and applications in language learning into three different parts: computer as tutor; computer as stimulus; and computer as tool. Using computers as a tool means that the computer teaches grammar, listening, pronunciation, reading, vocabulary, text reconstruction, writing, and comprehension. Using the computer as a stimulus means that the computer is used to help learners generate discussions, synthesize information, critical thinking, and discussions. Grammar 
checkers, word processing, concordance, reference, collaborative writing, internet, and authoring programs are typical uses of computers as a tool (Warschauer, 1996). The current stage of CALL has different applications that meet different learner needs in different language skills. Computers today offer learners a series of applications in each skill. Warschauer and Healey (1998) illustrated different applications of CALL. Speaking applications incorporate voice recording and playback to allow learners to compare what they said with the model. Another application is the drill applications. Drill applications contain games that use the power of computer and competition for collaboration to motivate language learning. Writing applications involve programs that help learners in the pre-writing stage to create and outline their ideas. other writing applications are word processing, spell checkers, and dictionaries. Sokolik (2001) stated that computers offer language learners six applications: drills, adaptive, testing, corpora and concordance, computer mediated communication, and multimedia production.

Beatty (2003) provides a wider range of CALL applications. These applications are found in almost all recent CALL labs: 
1. Word processing: word processors come under the method that computer is used as a tool (Warschauer, 1996). It is the basic CALL application that offers both a package of advanced writing tools (Pennington, 2004). It also enhances learners' motivation toward writing which leads to more practice (Dunkel, 1990). What makes word processing programs very powerful in CALL is that they are everywhere, costefficient, simple to learn, and provide great service: producing text (Esling, 1991). Pennington (2004) wrote:

the value of word processors for writing is generally considered to be their capacity to ease the mechanical processes of generating texts: revising text by deletions, additions, substitutions, block moves; and the production of clear and attractive finished copy. Beyond these writing and revision tools, the attributes and capabilities of the computer writing environment that aid the writing process include the following: the physical ease of making keypresses and typing text; the focusing of attention by the clear and restricted amount of text that is visible on the computer screen; the marking of the point where text is being produced by the blinking cursor, which also acts as a prompt to the writer to keep writing; the writer's awareness of the 
possibility of saving or changing text at any time. ( $p$. $72)$.

A good program of word processor is Microsoft WordC which is increasingly used by both learners and teachers for creating learning materials providing tables, texts, and simple websites (Beatty, 2003).

2. Games: the aim of using games for pedagogical purposes is to make learners unaware of the objectives, which means that learning takes place as an activity that is peripheral to play (Beatty, 2003). Hertz (1987) said that the fascination that the games offer for both adults and children is tempting for teacher-programmers to emulate these games in favor of subjects they teach. Hanson-Smith (1999) said that games could improve deductive and inductive reasoning, prediction strategies, and estimating abilities. Azriel et al. (2005) said that games give learners a creative environment which helps them to work with their peers, solve problems, and also communicate with each other, so learners then become involved in an active way in the learning process which would improve their motivation. Hangman` is an example of a game application that is used to teach spelling by providing learners hints about the missing letters of the target word 
(Beatty, 2003). The Sims $\odot$ is also a game that is designed to simulate different situations of everyday life (Purushotma, 2005) .

3. Literature: literature applications mean giving learners different literature from different disciplines (Beatty, 2003). Beatty (2003) said that literature "has a high degree of fidelity, or authenticity, in that the learning materials are both extensive and taken from real-world source" (p. 57). Collie and Slater (1987) looked at the use of literature in language teaching as: an authentic material, language enrichment, and personal involvement. Literature applications offer learners exposure to different styles, genres, contexts, terms, vocabulary, and acronyms in different fields in the language they learn.

4. Corpus linguistics: corpus linguistics refers to the study of the body of texts (Beatty, 2003). It "involves the examination of linguistic phenomena through large collections of machine-readable texts" (Cheng et al., 2003, p. 174). The main goal of corpus linguistics is to figure out the models of authentic language use through actual usage analysis (Krieger, 2003). Chapelle (2001) said "corpus linguistics tends to focus on the results that can be obtained through observation of large database comprised of texts" (p. 36). For example, researchers, teachers, or learners could examine 
the use of simple present tense to find out when it is used in speaking versus writing or in media versus journals. The term corpus is a kind of databank that has natural texts combined from recorded speech transcription and written texts (Krieger, 2003). A concordance is one way of using corpus linguistics applications. Krieger (2003) said that a concordance is a software program that is used to analyze the corpus and give the results (Krieger, 2003). St John (2001) defined a concordance as a list of the occurrences of a particular word, a part of a word, or a combination of words in context and it is drawn from a text corpus, which is presented in context. Betty (2003) said:

a concordancer is a tool that looks at individual words (nodes) or group of words and lists them with their immediate contexts, usually the seven or eight words that come before and after but in some cases the entire sentence for each work. The term for describing this approach is the key word in context (KWIK). (p. 60)

Corpus linguistics applications help teachers develop their learning material by offering them learners systematic errors (Beatty, 2003). Chapelle (2001) considers corpora as a central area for computer applications in Second Language 
Acquisition that helps learners create their own profile of words, meanings, and uses. It helps learners by giving them a window to the use of authentic language that is derived from real contexts rather than constructed for pedagogical purposes (Krieger, 2003). Yoon and Hirvela (2004)

illustrated an example of how corpus linguistics helps learners in writing. They said that if an English learner wants to use the word "'access'" in an essay might be confused about which words best collocate or link with that word "access". By connecting to a corpus database and then typing in the word "'access"' the student would eventually be able to see a long list of uses of that word with different collocations. The following example shows this process after using the corpus database to find out the uses of word '“access'" :

film and tv producers worldwide access to locations available for shooting.

a particularly easy and fruitful access to that area of the mind.

REP: their own military contacts to gain access to the arsenals, and within hours

Arab landowner: his bedroom, with access to the boudoirs of his three wives, seem to be when children have access 
to wide green spaces in which. (Yoon \& Hirvela, 2004, p. 257-258)

Teachers could benefit form corpus linguistics in syllabus design, classroom activities, and material developments (Krieger, 2003).

5. Computer mediated communication (CMC): CMC is seen today as one of the computers applications that has the greatest impact on the field of language learning (Warschauer, 1996). Warschauer (2004) said that the goal of interaction is seen as a tool to help language learners entering new societies and communities and familiarizing themselves with new discourses and genres. He believes that it is no longer sufficient for learners to communicate with other merely to practice what they learned in language classrooms. Peterson (1997) said that one of the main advantages of CMC is promoting autonomy in learning by providing an environment for learning that is less restrictive than the one in the conventional classroom. It enables language learners to communicate inexpensively with native speakers of the target language as well as with other language learners 24 hours a day, and from different places like classroom, home, or work (Warschauer, 1996). 
CMC also makes learners from different levels, backgrounds, types, and learning styles equal. Warschauer et al. (1996) stated that CMC applications provide more equal participation to learners who are often discriminated against or excluded, including minorities, shy students, women, and learners with strange learning styles. Chapelle (2003) wrote that CMC activities offer a variety of participant configurations which means that one learner can send a message to another one; one student can send to many others; or groups of learners can send messages to other groups. She believes that learners today are not confined to the topics proposed by their instructors. They can rely on their own experience and knowledge and discuss information and opinions of others and other topics through bulletin board (Chapelle, 2003). She added that communication through the CMC has given learners great opportunities for input that are not available in face-to-face communication. She added that language learners:

can lurk in a discussion perhaps to benefit from the input without being pressed to produce any language. If and when learners choose to participate, the interactive written language in computer-mediated communication on the internet means that learners do not have to reveal 
an accent in their oral language, and they have more time to reflect on and even correct their language, if they choose to do so. ( $p .15)$

Kern (1995) found that discussions through CMC offer students more opportunities than oral discussions to express and produce language. He also found that the quality of language produced is more sophisticated in term of morphosyntactic features and the variety of discourse functions.

There are two kinds of CMC, Synchronous and Asynchronous. Synchronous CMC means that the interaction is taking place in real time. The example of that is when learners sit in front of the computer, read, respond, and discuss topics with each other (Chapelle, 2003). This type of CMC could also take place over the internet through text messaging, voice messaging, or both (Chapelle, 2003). Smith, et at. (2003) said the internet is the representative of synchronous communication. They said "Internet Relay Chat (IRC) exemplifies synchronous communication" (p. 705). The second kind of CMC is Asynchronous communication. Asynchronous communication is the opposite of synchronous and means that interactions do not take place in real time. Examples of Asynchronous communication are bulletin boards 
(Chapelle, 2003) and e-mail (Smith et al., 2003). Bulletin boards are where learners and teachers post and share their messages with others. The advantage of bulletin boards is that the messages can be viewed, shared, and commented with different people around the world and not necessary with other learners or teachers, which gives it an extra advantage over email (Beatty, 2003). Email is considered one of the most common activities that learners use on the internet that gives them different advantages like recording both their own messages and those which they receive and communicating with their teachers, peers, and native speakers of the target language (Beatty, 2003). Peterson (1997) stated that email and asynchronous conferencing are the most common applications of CMC that are found in language classroom. WebCT, Multi-User domains Object Oriented (M00), Multi-User Adventure (MUA), Multi-User Domains/Dungeons (MUD), MultiUser Shared Hallucination (MUSH), and Multi-User Game (MUG) are examples of programs used in CMC (Beatty, 2003). 6. World Wide Web (WWW) resources: the WWW offers both learners and teachers an endless source of authentic materials that include handouts; texts; sound; video; and images (Beatty, 2003). It provides them a natural environment of the language to be taught or learned (Yang \& Chen, 2006). Hiple and Fleming (2002) stated "The world wide 
web consists of resources and users on the internet utilizing HTTP (Hypertext Transfer Protocol), a set of rules for exchanging files, including text, graphic images, sound, video, and other multimedia" ( $p .5)$.

Mosquera (2001) said that what gives the WWW a great importance is that the language used is not prefabricated language that is used in most of the language textbooks, but a real and authentic one. It enhances literacy, interaction, empowerment, and validity in language teaching (Taylor \& Gitsaki, 2004). Mosquera (2001) illustrated some features that the WWW offers learners to practice: reading newspapers and magazines online; visiting libraries; accessing tourist information; listening to radio programs; watching TV; and visiting museums. Through the WWW, learners are able to learn and practice all language skills; reading, writing, listening, and writing in real world situations and they can also acquire different knowledge forms (Yang \& Chen, 2006). There are many websites that offer materials for learners and teachers. Some of them are commercial and many are free.

New Dynamic English Program

New Dynamic English (known as DynEd) is the only program used at all CALL labs in the IPA. DynEd consists of four 
language levels (see Table 2.3) and each level has two modules and two disks. The $1^{\text {st }}$ level is for beginner, the $2^{\text {nd }}$ level for low intermediate level learners, the $3^{\text {rd }}$ is for intermediate, and finally the $4^{\text {th }}$ is for upper-intermediate and advanced level students (Fitzgeral, Bower, \& Morrall, 1999). In each level, there is a Matrix Vocabulary lesson that motivates learners to discover the language and language structures in different contexts and categories, like weather, months of the year, and times of life. There are also a Video Interaction lessons that support learners to watch and listen to a video clip, and after listening the learners fill in the missing parts of the speech in the clip they watched (Fitzgeral, Bower, \& Morrall, 1999). Fitzgeral et al. (1999) illustrated some features that DynEd has. The program offers help for learners on how to use, how to record, and some hints on what the learner needs to do in each part. It also has a feature of speech that allows the learner to reset all the audio files and slow down the speech speed. The program also keeps a file of all recorded speech that the user produced and can be printed. The main feature of the program is a "shuffler" which means that the program progress depends on the student's performance on the lesson exercises. For example, if the learner correctly answers the majority of the questions, the program automatically will 
raise the difficulty of the following questions. The program covers listening and speaking; vocabulary; grammar; oral presentations; and reading skills (DynEd).

Table 2.3. Contents of the New Dynamic English Software

\begin{tabular}{|l|l|}
\hline Level 1Disk 1 & Level 2 Disk 2 \\
\hline Names \& Places & Family Schedule \\
Jobs \& Family & Matrix Vocabulary \\
Numbers \& Time & Likes \& Dislikes \\
Video Interactions & Video Interactions \\
\hline Level 2 Disk 1 & Level 2 Disk 2 \\
\hline Daily Activities & Planning Ahead \\
Our World & Matrix Vocabulary \\
Locations & Biography \\
Video Interactions & Video Interactions \\
\hline Level 3 Disk 1 & Level 3 Disk 2 \\
\hline On a Trip & Life Experience \\
Energy Sources & Matrix Vocabulary \\
Directions & Comparisons \\
Video Interactions & Video Interactions \\
\hline Level 4 Disk 1 & Level 4 Disk 2 \\
\hline Life Choices & The Secret Code - A Mystery \\
Epidemic & Matrix Vocabulary \\
Space \& Time Sequences & UFOs: For \& Against \\
Video Interactions & Video Interactions \\
\hline
\end{tabular}

Table Adapted from Fitzgeral, Bower, \& Morrall (1999)

\section{Notion of Attitude}

The word "attitude" is a term with different meanings in different fields. It is a main concept in both Psychology and Sociology, one of the central concepts of Social Psychology (Strauss, 1945), and the main occupation of social psychologists since the 1950s (Greenwald, Brock, \& Ostrom, 1968). Early researchers like Bain (1928) looked at 
attitudes as "the relatively stable overt behavior of a person which affects his status". Thurstone (1946) defined attitudes "as the intensity of positive or negative affect for or against a psychological object. A psychological object is any symbol, person, phrase, slogan, or idea toward which people can differ as regards positive or negative affect"(p. 39). For Rokeach (1976), "attitude is a relatively enduring organization of beliefs about an object or situation predisposing one to respond in some preferential manner" (p. 530). Zimbardo \& Leippe (1991) saw attitudes as "an evaluative disposition toward some object based upon cognition, affective reactions, behavioral intensions, and past behaviors" (p. 31). Palaigeorgiou, Siozoz, Konstantakis, \& Tsoukalas (2005) defined attitudes as "a positive or negative sentiment, or mental state, that is learned and organized through experience and that exercises a discrete influence on the affective and conative responses of an individual toward some other individual, object or event? (p. 331). According to Bromely (1995), attitude indicates the affect and that it is both emotional and evaluative and shows the degree to which you like or dislike the attitudinal object .

Most of the recent attitude studies linked it with cognitive and affective organization with regard to some 
object and with respect to a predisposition to act (Reed, 1991). Wenden (1991) said that attitudes involve cognitive component that deals with beliefs or perceptions about an object or a given situations, an evaluative component which is mainly like or dislike for the object, and a behavioral component that guides particular behavior. In addition, many attitude theories in psychology suggest that attitude consists of three components: (1) affect: which refers the degree of like the person has; (2) cognition: which refers to the person's knowledge about the attitudinal object; and (3) behavior which is related to reactions and intensions regarding the object (Bromley, 1995). The knowledge of attitude allows the prediction of behavior and consequently the change of a belief would lead to a change or modification of behavior (Reed, 1992; White, 2007).

Attitude and Language Learning

Studies of attitude in language learning started in the mid-sixties (Smith, 1971). Smith (1971) wrote “by the midsixties disquieting feelings began to emerge on the pages of all the foreign language journals. Something was amiss. Something had been overlooked, an important factor that we are only now beginning to investigate: attitudes" (p. 82). 
Attitude is considered one of the affective variables that have a great role in second or foreign language acquisition (Ganschow, Sparks, Anderson, Javorshy, Skinner, \& Patton, 1994). The questioning of the role of affective factors in language learning came as a possible answer for the question; how it is possible for some people to learn a second language perfectly and proficiently whereas others, with the same opportunities and conditions to learn are failures, since all other answers attributed to teaching methods, knack, or pedagogical matters have failed (Gardner \& Lambert, 1972). Early pioneering works of Gardner and Lambert (1995) \& (1972) opened the door for the studies of affective variables and brought them to the fore of research (Bacon \& Finnemann, 1990).

The Monitor Theory of Krashen proposes the role of affective filter in language acquisition (see Figure 2.3) has had a large impact on the role that affective factors play in language acquisition (Bacon \& Finnemann, 1990). Krashen (1987) describes the hypothesis of an affective filter as:

The Affective Filter Hypothesis captures the relationship between affective variables and the process of second language acquisition by positing that acquirers vary with respect to the strength or level of 
their Affective Filters. Those whose attitudes are not optimal for second language acquisition will not only tend to seek less input, but they will also have a high or strong Affective Filter - even if they understand the message, the input will not reach that part of the brain responsible for language acquisition, or the language acquisition device. Those with attitudes more conducive to second language acquisition will not only seek and obtain more input, they will also have a lower or weaker filter. They will be more open to the input, and it will strike "deeper". (p. 31)

Figure 2.3 The Role of Krashen's Affective Filter Hypothesis on the Second Language Learning

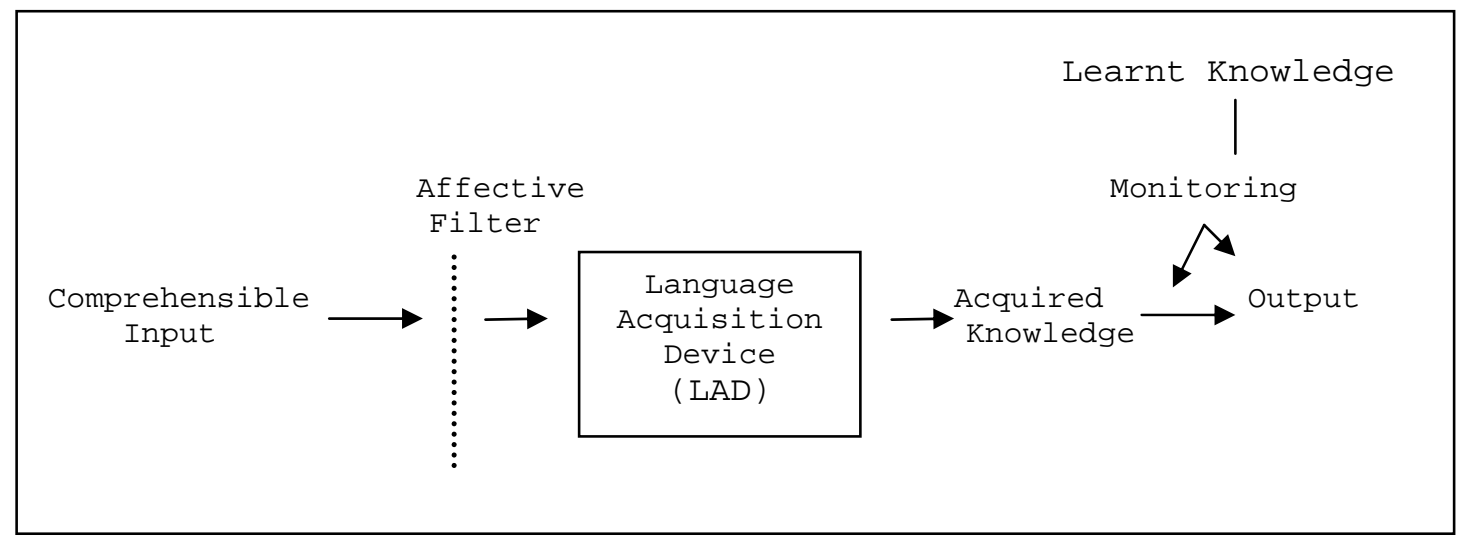

Figure Adapted from Cook (2006)

The importance of attitudes in language learning and acquisition has been stressed by many other researchers 
(Savigon, 1976; Gardner \& Lambert, 1972; Merisuo-Storm, 2006; Ellis, 1985). Savignon (1976), for example, considers attitude as the most important factor in second language learning. Attitude also correlates with other affective factors. For example, it plays a role in the formation of motivation toward language learning itself (Gardner \& Lambert, 1972). Gardner \& Lambert (1972) wrote that "the learner's motivation for language study, it follows, would be determined by his attitudes and readiness to identify and by his orientation to the whole process of learning a foreign language" (p. 134). Merisuo-Storm (2006) supported that claim by saying that motivation in language learning usually refers to stable attitudes in learners' mind. Ellis (1985) discussed the importance of attitudes and motivation in language acquisition stating that attitudes and motivation are crucial factors that help in determining the proficiency level that different learners achieved.

Attitudes toward learning situation, according to Masgoret \& Gardner (2003), refer to "the individual's reaction to anything associated with the immediate context in which the language is taught" (p. 173). The importance of attitudes toward the language learning setting is very important for success. Merisuo-Storm (2006) wrote "negative attitudes towards language learning can reduce learners' 
motivation and harm language learning, whereas positive attitudes can do the opposite" (p. 228). Lin \& Miller (2005) said "We may wish to obtain measures of student's attitudes toward certain classroom activities, the textbook, laboratory experience, or our own instruction so that needed adjustments can be made" ( $p .324)$. oxford (2001) said that examining learners' attitudes is very important for teachers. Bromley (1995) stated that "attitudes influence the efforts that students expend to learn another language, then language teachers need a clear understanding of attitudes and attitude-change theory in order to address these issues in the classroom"( $p .373)$.

Obtaining learners' attitudes would undoubtedly help instructors understand their students, modify their ways of teaching, as well as the whole course syllabus.

Attitude toward Computers in Instruction

There are many definitions of attitude toward computers (Smith, Caputi, \& Rawstorne, 2000). Smith et al. (2000) defined attitudes toward computers as "a person's general evaluation or feeling of favourableness or unfavourableness toward computer technologies (i.e. attitude toward objects) and specific computer-related activities (i.e. attitudes 
toward behaviours" (p. 61). The evaluation according to Smith et al., (2000) could be applied to all computer technologies like attitude towards computer programs, training, and games as well as computer-related activities including behavioral diminutions like using computer. This definition is consistent with Ajzan and Fishbein's (1977, 1980) theory of reasoned action (Smith, et al., 2000) which posits that beliefs about objects form the attitudes toward them (Ajzan \& Fishbein, 1977 - see Figure 2.4). Mitra and Hullett (1997) found that attitudes toward computers consist of many elements like attitudes toward computer in instruction, technical support in computer, and attitude toward access to computers. Palaigeorgiou, et al. (2005) wrote that computer attitude evaluation usually involves statements that assess the persons' interactions with computer hardware, software, other people relating to computers, and activities that encompass computer use. 
Figure 2.4 Ajzen \& Fishbein's (1977) Theory of Reasoned Action.

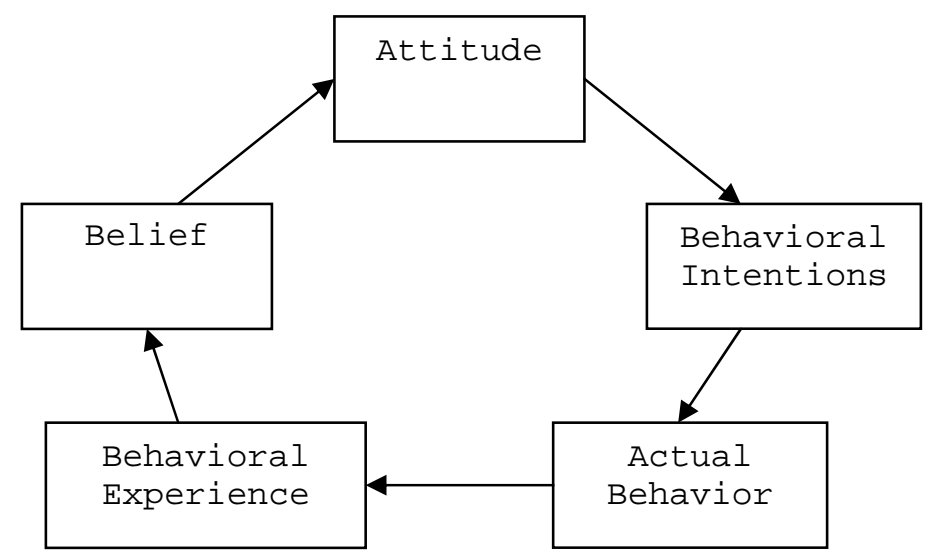

Figure Adapted from Jung (2006).

Computer anxiety is a central factor in attitudes toward computer use. Schottenbauer, Rodriguez, Glass, \& Arnkoff (2004) stated that computer anxiety predicts attitudes toward computers. Computer anxiety is defined as the "fear of impending interaction with a computer that is disproportionate to the actual threat presented by computers" (Howard, Murphy, \& Thomas, 1987, p. 15). Bozionelos (2001) wrote computer anxiety refers to "negative emotions and cognitions evoked in interactions with computer-based technology" (p. 313).

The use of computers in instruction has opened the door for research to discuss all related aspects to computer use in teaching. Learners are one of the main variables that researchers have addressed to get more understanding of 
integrating the use of technology in classrooms. Students' attitudes toward using technology in classrooms represent a high importance in the success of implementation of technology. Al-Khaldi \& Al-Jabri (1998) stated that students' attitudes toward computer are significant determinants that might affect the success of computer implementations. The success of any integration of the use of computers in instruction depends greatly on learners' and teacher's attitudes toward them (Selwyn, 1999, cited in Palaigeorgiou, et al., 2002).

Several studies have been conducted to assess students' attitudes toward the use of computers in instruction. Chen (2003) administered a study to investigate EFL learners' attitudes toward the use of computers in EFL instruction at National Cheng Kung University in Taiwan. The findings of the study showed that the participants significantly showed positive attitudes toward the integration of computers in their EFL study. Ayres (2002) conducted a study at the School of English and Applied Linguistics at UNITEC Institute of Technology in Australia to see how learners perceive the role of CALL in their study. He concluded that learners hold positive attitudes toward the use of computers in their learning. The study also shows that $80 \%$ of learners believe that CALL is relevant to their needs, $77 \%$ of students said 
that the tasks of CALL give them very useful information, and $66 \%$ believe that the use of CALL should be used more in their studies. Min (1998) investigated the attitudes of Korean adult English language learners toward the use of computers in EFL classrooms. The study showed that the selected sample of Korean adult language learners did not hold positive attitudes toward the use of computers in English language settings. Lin (2002) investigated Taiwanese learners' attitudes and motivation toward the integration of computers in college-level EFL reading and writing in three universities: public, private, and military. He found that students have positive attitudes and are highly motivated toward the use of computers. Liu (1997) conducted a study that investigated Chinese students at The University of Tennessee toward computers. Chinese students generally showed positive attitudes toward the use of computers in their university studies.

In the Arab world, Stevens (1991) investigated Arab EFL learners' attitudes toward CALL and found that learners enjoy using computers. They said that computers have improved their English and they looked at computers as an important factor in their English learning. Almekhlafi (2006) conducted a study that explores United Arab Emirates EFL learners' achievement and attitudes toward CALL. The study 
revealed that students have positive attitudes toward CALL. They perceive it as a very helpful tool in learning EFL and have a strong desire to use it more in future. Jabir \& Omar (2000) investigated the attitudes of both learners and teachers in Southern areas of Jordan. Their study investigated 700 students and 47 teachers (male and female). The findings of their study showed that both learners and teachers hold positive attitudes toward the use of computers and want more use of computers in their classrooms. Yushau (2006) conducted a study to examine the influence of blended e-learning on learners' attitudes toward mathematics and computers at King Fahd University of Petroleum and Minerals (KFUPM) in Saudi Arabia. Data collected from 70 Saudi students of the preparatory year program at beginning of the program (pre-program) and at the end of it (post-program). For measuring computer attitudes, Yushau (2006) used Computer Attitude Scale (CAS) (Loyd \& Gressard, 1984). The findings of the study showed that learners at KFUPM in the preparatory year program hold positive attitudes toward the use of computers and believe that computers help them in their study. The results of the study also showed that the Saudi learners want more use of computers in their study. The first independent variable of the study is the years of English learning. The study aims to determine whether 
this variable can be a predictor of Saudi EFL learners' attitudes toward CALL at the IPA. As for the years of English learning variable, few studies have been conducted to address or measure students' attitudes toward computers based on their English learning. There is no enough literature on whether English knowledge has a role in determining EFL learners' attitudes toward the use of computers. One study conducted by Chen (2003) investigated EFL learners' attitudes toward using technology in classroom in Taiwan based on learners' English background. She found that there were no significant differences in learners' attitudes toward the use of computers based on their English knowledge.

Computer knowledge is the second variable of this study seeking to predict Saudi EFL students' attitudes toward CALL at IPA. The influence of computer knowledge on attitudes toward computers has been addressed by many studies. Computer knowledge indicates that the person has enough ability to use and deal with computers in different situations. Computer use, according to Reinen \& Plomp (1993), is divided into two parts, the first includes learning with computers, for example, CAI and tutorial, where as the second part includes learning about computers, examples are computer literacy. Computer literacy, according to Loyd and Gressard (1984), means the ownership of computer, 
amount of time people spend in front of a computer, and the number of courses people took that were related to computers. Hence, computer familiarity plays a central role in forming students' attitudes toward the use of computers in instruction. That is, people who are generally experienced or familiar with an object hold more positive attitudes and less anxiety toward the object.

Most of the studies show that computer experience is a central factor in determining students' attitudes toward computers. Chen (2003) investigated college EFL learners' attitudes toward the use of computers in Taiwan based on their computer experiences. She measured learners' attitudes in three dimensions in the study: attitudes toward computer use, attitudes toward the ease of computer use, and attitudes toward computer usefulness. The findings of her study showed that significant differences existed in three dimensions. She found that EFL students who spend five hours or more everyday on computer held more positive attitudes toward the three dimensions (computer use, computer easiness, and computer usefulness) than did EFL students who spent one to five hours or one hour or less. Liu (1997) concluded that the more computer experience learners have, the more positive attitudes toward computers they hold. Loyd and Gressard (1984) examined the effects of computer experience on 
attitudes toward computers among 107 community college students, 142 high school language arts students, and 105 students living in dormitories at a small college. Computer attitudes (computer anxiety, computer confidence, and computer liking) were measured by the Computer Attitude Scale (CAS) (Loyd \& Gressard, 1984). The findings of the study showed that computer experience was significantly related to more positive attitudes on all three subscales. Ruffin (2000) conducted a study to investigate the relationship between demographic variables and college students' attitudes toward the use of computers in instruction. Demographic variables include mathematics aptitude, level of education, rank, race, gender, age, computer-related experience and computer science experience. The results of the study showed that the average daily exposure to computer and computer science courses, beside race were the three best predictors of learners' attitudes toward the use of computers in instruction. Mcllroy, Bunting, Tierney, \& Gordon (2001) assessed 193 undergraduate students in relation to computing anxieties and attitudes. They found that students who had frequent access to computers held more positive attitudes but no advantage in computer anxiety. In addition, the findings showed that a positive first computer experience appeared to mitigate anxiety. The meta-analysis study of chua, chen, \& 
Wong (1999) stressed that the computer anxiety is strongly related to computer experience. Their study suggested that the more computer experience the students have, the less computer anxiety they show and vice versa. Igbaria \& Chakrabarti (1990) assessed 187 graduate students to examine the effect of computer experience on computer anxiety. They concluded that computer training decreased students' computer anxiety and indirectly played a role in students' attitude toward computers.

Gender is the third independent variable of this study in predicting Saudi EFL learners' attitudes toward CALL. Gender was also among the main variables that many studies chose to investigate learners' attitudes toward computers. Studies on gender differences on attitudes toward computers have found mix results. Chua et al. (1999) conducted a metaanalysis study investigating the relationships between computer anxiety and three correlates-age, gender, and computer experience. The analysis included studies published between 1990 and 1996. As for gender, the findings of the meta-analysis showed that female university undergraduate students have more anxiety than the male students. Shashaani (1997) conducted a study to examine the gender gap in attitudes toward computers among college students. She found that male students were more interested in computers and had 
more positive attitudes than female students. Taghavi (2001) investigated gender influence on college students' attitudes toward using computers in teaching. He found that gender did not significantly affect the learners' overall attitudes toward computer. Anderson (1996) assessed the role of gender in computer anxiety among 64 undergraduate students, and found that gender was not a predictor of computer anxiety. Chin (2001) conducted a study to see if there are differences exist between Taiwanese learners' attitudes toward computers based on their gender. The study showed that Taiwanese male students having more favorable attitudes towards computers than female students. Brosnan (1998) studies the gender differences in computer attitudes and anxieties of learners from UK versus Hong Kong. The study showed that in the UK sample, there were no gender differences with regard to computer anxiety, but that male learners had more positive attitudes toward computers than the did female learners. As with the Hong Kong sample, gender differences in computer attitudes were not significant, but male students showed more computer anxiety than their female counterparts. Jennings \& Onwuegbuzie (2001) investigated college students' attitudes toward computers based on their gender and showed no main effect of gender on the learners' attitudes. In Eastern Europe, Durndell \& Haag (2002) investigated Romanian college- 
level students' attitudes from different courses toward the use of computers in instruction and their computer anxiety. They found that male learners hold more positive attitudes toward the use of computers and lower computer anxiety than female students. In the Arab world, Abdelhamid (2002) conducted a study to see whether gender differences exist in attitudes and computer anxiety among 400 students at Cairo University in Egypt. The results showed that there were no significant differences in learners' attitudes toward computers. As for the computer anxiety, female students have more computer anxiety that their male peers. Based in these studies, the gender variable would represent a difference in attitudes toward the use of computers in some settings and would not in others. As we also saw, some studies showed that gender can be used as a predictor of computer anxiety, whereas other findings showed that gender makes no difference in computer anxiety prediction. 


\section{CHAPTER THREE: METHODOLOGY}

The purpose of the study is to identify EFL learners' attitudes toward CALL at the IPA in Saudi Arabia. The main goal is first to explore these attitudes and determine the relation between attitudes and learners' years of English learning, computer knowledge, and gender.

Understanding learners' attitudes toward CALL as a new technology at the IPA would make the use of CALL more effective as well as help learners, instructors, and administrators to gain the ultimate benefits from this technology. Therefore, the intention of the study was to explore these attitudes and to establish a mechanism to predict these attitudes in the future.

This chapter describes the procedures used in the study. It includes the research questions, design of the study, hypothesis testing, sample selection and population, and instrumentation.

\section{Hypothesis Testing}

The following null hypotheses, based on the research questions, will be answered. 
Research question 1: What are the Saudi EFL learners' attitudes toward CALL in general at the IPA?

Research question 2: What are Saudi EFL learners' attitudes toward the CALL software used at the IPA?

Descriptive statistics will be used to address research question 1 and research question 2. Namely, the mean value and standard deviation will be conducted. Therefore, no null hypotheses were set for these two research questions.

Research question 3: What are the differences between Saudi EFL learners' attitudes toward CALL at the IPA based on their years of English learning?

Null hypothesis 3: There is no statistically significant difference among Saudi EFL learners' attitudes toward CALL at the IPA based on their years of English learning.

Research question 4: What are the differences between Saudi EFL learners' attitudes toward CALL at the IPA based on current computer knowledge?

Null hypothesis 4: There is no statistically significant difference among Saudi EFL learners' attitudes toward CALL at the IPA based on their computer knowledge. Research question 5: What are the differences between Saudi EFL learners' attitudes toward CALL at the IPA based on their gender? 
Null hypothesis 5: There is no statistically significant difference among Saudi EFL learners' attitudes toward CALL at the IPA based on their gender.

\section{Sample selection and Population}

Sampling is "the process of selecting a number of participants for a study in such a way that they represent the larger group from which they were selected" (Gay, Mills, \& Airasian, 2006, p. 99). The sample is a group of people chosen from a population to represent the population in a research study (Gravetter \& Wallnau, 2007).

The population of the study consists roughly of $1500 \mathrm{EFL}$ learners of four IPA campuses in Saudi Arabia. These include two campuses in Riyadh (separate men's and women's campuses), a campus in Dammam, and a campus in Jeddah. Intensive English program at each campus is divided into four English levels: preparatory, elementary, intermediate, and advanced. Each level lasts for two months and passing the level requires the learners obtain an overall level grade of $60 \%$ or higher. 
Table 3.1 Numbers of Saudi EFL learners at IPA Campuses

\begin{tabular}{|c|c|}
\hline IPA campus & Number of learners \\
\hline $\begin{array}{c}\text { Riyadh } \\
\text { (men campus) }\end{array}$ & 950 \\
\hline $\begin{array}{c}\text { Riyadh } \\
\text { (woman campus) }\end{array}$ & 155 \\
\hline $\begin{array}{c}\text { Dammam } \\
\text { (men campus) }\end{array}$ & 230 \\
\hline $\begin{array}{c}\text { Jeddah } \\
\text { (men campus) }\end{array}$ & 130 \\
\hline
\end{tabular}

With 950 students divided into the four levels, Riyadh men's campus is the largest. The researcher used the cluster sampling technique. Cluster sampling is used with groups, not individuals, which are randomly selected (Gay, et al., 2006). Hence, different groups from each English level at Riyadh men campus were randomly selected. For assuring that the selected sample will properly represent the target population, and based on the statistic rule stating that the larger the sample, the more precisely it reflects the population and the more reliable the study, the researcher obtained information from 192 of Riyadh men campus population which approximately represents $20 \%$ of the Saudi EFL learners population at Riyadh men's campus.

Riyadh women's campus population consists of 155 Saudi female EFL learners. Unlike Riyadh men's campus, not all English levels are available at Riyadh women's campus. Usually two English levels are available every semester. 
These two levels are either preparatory and intermediate or elementary and advanced. A total of 126 Saudi women EFL students at Riyadh women's campus participated in the study and that represents almost $81 \%$ of the Riyadh women's campus's population.

Dammam men's campus is the second largest IPA campus. It has 230 Saudi EFL learners divided unequally into four English levels. The majority of learners are divided into two levels. These two levels are either preparatory and intermediate or elementary or advanced, depending on which semester of the year. The data were collected form 140 participants. Those participants stand for $60 \%$ of the whole population of English students at Dammam men's campus. Jeddah men's branch is the smallest IPA campus. There are 130 Saudi EFL learners . Like the Riyadh women's branch, not all English levels are conducted every semester. The researcher gained information from 120 learners and that roughly represents $92 \%$ of the population.

Instrumentation

Development of Instrumentation

The instrument of this study (see Appendix A for English version and Appendix B for the Arabic version) consists of 
two parts (see Figure 3.1). The first part includes demographic information. The demographic information consists of 10 items that seek information and is divided into these categories: IPA location of study, gender, age, years of English study, academic major at the IPA, and computer knowledge (ownership of computer, years of computer experience, hours of daily computer use, and self-evaluation of computer experience).

Figure 3.1 Instrumentation of the Study

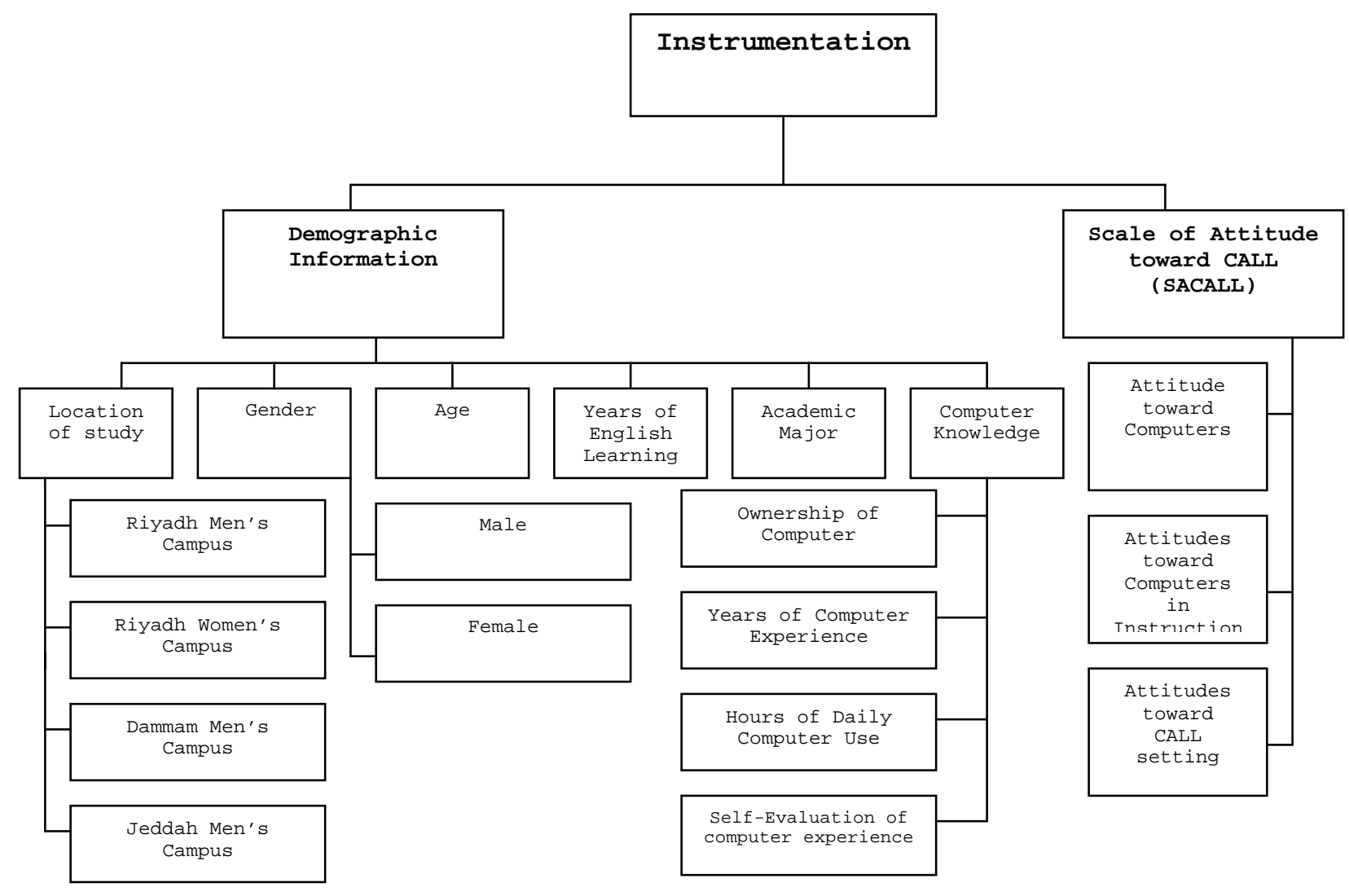


The second part includes a scale designed by the researcher for measuring learner attitudes toward CALL. The researcher titled the scale the Scale of Attitude toward CALL (SACALL). SACALL consists of 30 items aimed to measure learner attitudes toward CALL. These items were divided into three subscales: the first two subscales focus on attitudes toward computers in general and the use of computer in language instruction (20 items). The last subscale concentrates on the attitudes toward the CALL lab (ease of use and integration into the English language program). A five point Likert-scale is used in SACALL: Strongly Agree = 5, Agree $=4$, Uncertain $=3$, Disagree $=2$, and Strongly Disagree $=1$. The highest the score, the more positive attitudes the learner holds toward CALL. Based on that, score 5 means high positive attitude, score 4 means positive attitudes, score 3 means neutral attitudes, score 2 indicates negative attitude, and finally score 1 shows very negative attitude toward the CALL.

In designing this scale, the researcher reviewed many surveys that measure attitudes toward computers. Two computer attitudes scales were chosen to be adopted in this study: the Computer Attitude Scale (CAS) (Loyd \& Gressard, 1984a) and Scale of Educational Technology Attitude (SETA)( Chen, 2003). Both scales were used to measure attitudes 
toward the computers and the use of computers. The researcher received permission to adopt both scales (see Appendix C).

The Computer Attitude Scale (CAS) was developed by Brenda Loyd and Clarice Gressard in 1984. The first version of the CAS consisted of 30 items divided into three categories: computer anxiety, computer confidence, and computer liking (Loyd \& Gressard, 1984a). In 1985, a fourth subscale called computer usefulness was added by Loyd \& Loyd (Loyd \& Loyd 1985). Hence, the CAS has 40 items divided into four categories: computer anxiety, computer confidence, and computer usefulness. Each subscale consists of 10 items. A four point Likert-type scale is used in the CAS (strongly agree, agree, disagree, and strongly disagree). The higher scores correspond to a more positive attitude, e.g., a higher confidence score means more confidence and a higher anxiety score means less anxiety (Loyd \& Loyd, 1985). The CAS scale reported Cronbach-alpha reliability coefficients of .90, .89, .89 , and .82 for subscales and 0.95 for the total (Loyd \& Loyd). Woodrow (1991) compared four computer attitudes scales and stated that CAS is the most used and tested scale. Pope-Davis and Vispoel (1993) assessed the influence of computers instruction on attitudes toward the use computers using CAS. They stated that the reliability analyses of CAS subscales: computer anxiety, computer confidence, computer 
liking, and computer usefulness, showed coefficient alpha of $.91, .88, .88, .92$. respectively (Pope-Davis \& Vispoel, 1993 cited in Chen, 2003).

The second scale adopted in this study is the scale of Educational Technology Attitudes (SETA) developed by Pi-Ching Chen in 2003. The SETA consists of 30 items and two main subsections. The first subsection has 20 items on computer attitudes (CA), and the second subsection includes 10 items on internet attitudes (IA) (Chen, 2003). There are two dimensions in the CA subsection: computer easiness (CE) and computer usefulness (CU). There are 20 items equally divided between CE \& CU. In IA subsection, there are 10 items divided between E-mail use and items on WWW use (Chen, 2003). In developing the SETA, Chen (2003) adopted items from three scales; CAS (Loyd \& Gressard, 1984), computer readiness surveys (Wright, 1998), and internet resources surveys (Anderson, 2001). The SETA was used to assess Taiwanese EFL learners' attitudes toward the use of technology in EFL instruction. The cronbach-reliability coefficients of the SETA were .89 (Chen, 2003).

Translation of the Survey into Arabic

The rationale for translating the survey into Arabic is to make sure that learners understand all the survey items 
and to assure the reliability and validity of the findings. The researcher, with a B.A degree in English Arabic translation, initially translated the English version into Arabic. The translation was reviewed by two experienced translation professors holding PhD degrees in English Arabic translation, two EFL faculty members at IPA holding master degree in TESOL \& Applied Linguistics, and one professional translator with a master degree in Translation and 15 years of English Arabic translation. Based on the comments of the reviewers, few minor changes have been made to the translation.

Pilot study

For the reliability and validity of the survey, the researcher piloted the Arabic version of the survey along with the survey evaluation form (see Appendix D for English Version and Appendix $F$ for the Arabic version) to 20 IPA EFL men learners at Riyadh, Dammam, and Jeddah campuses, and to 10 Saudi learners studying English as a second language (ESL) in the United States, two of whom had finished the one year English program at the IPA. Based on comments from EFL learners in Saudi Arabia and ESL Saudi learners in the USA, minor changes have been made to the survey to be more understandable. 


\section{Design of Study}

The design of the study includes both descriptive and inferential statistics. The aim of the study is first to explore the current attitudes of Saudi EFL learners' attitudes toward CALL at the IPA, then to predict Saudi EFL learners' attitudes toward CALL in the future based on their years of English learning, computer knowledge, and gender. For questions one and two, the study will employ descriptive statistics including determining the mean and standard deviation for the selected sample. In addition, the study will use two means comparison (t-test) to determine weather gender difference exists between the men's campus at Riyadh and the women's campus in Riyadh.

To predict the future attitudes of Saudi EFL learners at the IPA the study will use inferential statistics. Namely the regression model will be used to create a predictive model (see Figure 3.2). 
Figure 3.2 Independent Variables Used to Predict Learners' Attitudes toward CALL.

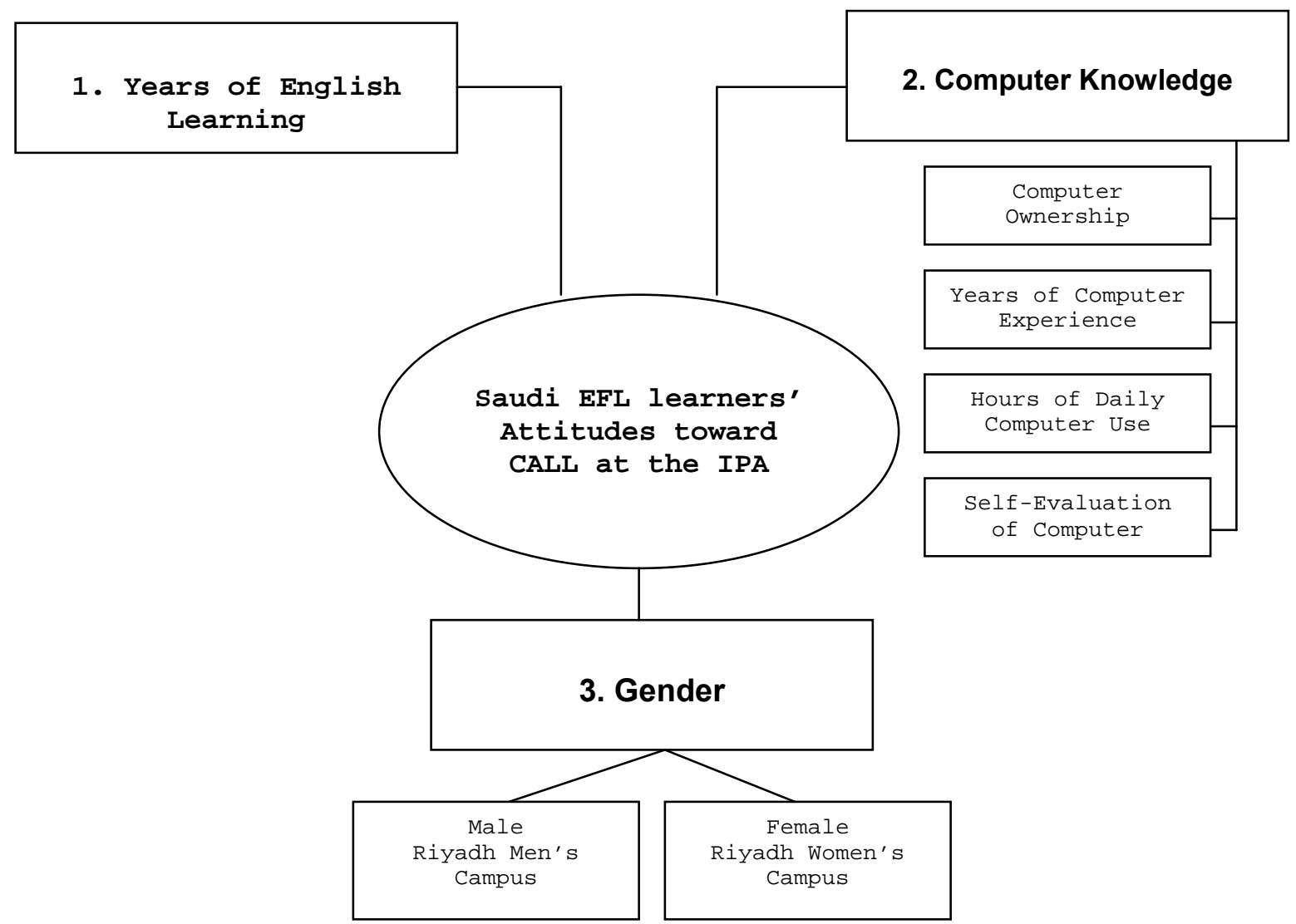




\section{CHAPTER FOUR: RESULTS}

Five questions have guided this study. The purpose of the study was to identify Saudi EFL learners' attitudes toward CALL at the Institute of Public Administration. The study also investigated three variables related to the saudi EFL learners' attitudes toward CALL. This chapter presents the results of the data analysis of this study. The data were analyzed by using the Statistical Software for Professionals (STATA) program.

Sample and Population

The population of the study consists of roughly 1500 Saudi EFL learners at different IPA campuses in Saudi Arabia. With 950 Saudi EFL learners, the men's campus of Riyadh is the largest IPA campus with all four levels of the English language program. The cluster sampling technique was used to ensure that all levels at the English language center in Riyadh men's campus were represented in the study. Random classrooms in each level were selected and the survey questionnaires were distributed to 100 learners in each level for a total of 400 total surveys. A total of 318 students at Riyadh men's campus participated in the study. Among these 
318 responses, 67 surveys were not completed and 59 were not valid. A total of 192 surveys were valid and usable (see Table 4.1). The mean of age for these 192 participants was 23.55 years. This sample represents $20 \%$ of the population at the IPA Riyadh men's campus.

Table 4.1 Riyadh Men's Campus Response Rate

\begin{tabular}{|l|c|c|c|}
\hline $\begin{array}{c}\text { English Language } \\
\text { Level }\end{array}$ & $\begin{array}{c}\text { Population (N) } \\
\text { (Number of } \\
\text { Learners) }\end{array}$ & $\begin{array}{c}\text { Number of } \\
\text { Distributed } \\
\text { Surveys }\end{array}$ & $\begin{array}{c}\text { Sample (n) } \\
\text { (Number of Valid } \\
\text { Surveys) }\end{array}$ \\
\hline Preparatory & 240 & 100 & 45 \\
\hline Elementary & 225 & 100 & 43 \\
\hline Intermediate & 236 & 100 & 45 \\
\hline Advanced & 249 & 100 & 59 \\
\hline Total & $\mathbf{9 5 0}$ & $\mathbf{4 0 0}$ & $\mathbf{1 9 2}(\mathbf{2 0 \% )}$ \\
\hline
\end{tabular}

As for the IPA women's campus in Riyadh, the population consists of 155 Saudi EFL women learners. These learners were divided into two levels of the English program: 76 Saudi EFL women learner were in the elementary level and 79 were in the advanced. The survey questionnaires were distributed to the entire population in the intensive English program at IPA women's branch in Riyadh. A total of 152 surveys were collected. Out of these 152 surveys, 9 surveys were not completed and 17 were not valid. The total of valid and usable surveys of IPA women's branch in Riyadh was 126 
surveys (see Table 4.2). The mean of age for these 126 women participants was 21.46 years. This sample represents $81 \%$ of IPA women's campus in Riyadh.

Table 4.2 Riyadh Women's Campus Response Rate

\begin{tabular}{|l|c|c|c|}
\hline $\begin{array}{c}\text { English Language } \\
\text { Level }\end{array}$ & $\begin{array}{c}\text { Population (N) } \\
\text { (Number of } \\
\text { Learners) }\end{array}$ & $\begin{array}{c}\text { Number of } \\
\text { Distributed } \\
\text { Surveys }\end{array}$ & $\begin{array}{c}\text { Sample (n) } \\
\text { (Number of Valid } \\
\text { Surveys) }\end{array}$ \\
\hline Elementary & 76 & 76 & 56 \\
\hline Advanced & 79 & 79 & 70 \\
\hline Total & $\mathbf{1 5 5}$ & $\mathbf{1 5 5}$ & $\mathbf{1 2 6}(\mathbf{8 1 \% )}$ \\
\hline
\end{tabular}

The population at IPA Dammam men's campus on the east coast of Saudi Arabia consists of 233 Saudi EFL learners divided as following: 34 learners in the preparatory level, 76 learners in the elementary level, 32 learners in the intermediate level, and 88 in the advanced level. The survey questionnaires were distributed to the whole population. A total of 185 responses were received. Out of these 185 surveys, 38 surveys were not completed and 7 surveys were not valid. A total of 140 valid and usable surveys were collected from IPA Dammam men's campus (see Table 4.3). The mean of age of Dammam participants was 21.88 years and they represent $61 \%$ of the EFL Saudi learners at IPA Dammam men's campus . 
Table 4.3 Dammam Men's Campus Response Rate

\begin{tabular}{|l|c|c|c|}
\hline $\begin{array}{c}\text { English Language } \\
\text { Level }\end{array}$ & $\begin{array}{c}\text { Population (N) } \\
\text { (Number of } \\
\text { Learners) }\end{array}$ & $\begin{array}{c}\text { Number of } \\
\text { Distributed } \\
\text { Surveys }\end{array}$ & $\begin{array}{c}\text { Sample (n) } \\
\text { (Number of Valid } \\
\text { Surveys) }\end{array}$ \\
\hline Preparatory & 34 & 34 & 25 \\
\hline Elementary & 76 & 76 & 34 \\
\hline Intermediate & 32 & 32 & 28 \\
\hline Advanced & 88 & 88 & 53 \\
\hline Total & $\mathbf{2 3 0}$ & $\mathbf{2 3 0}$ & $\mathbf{1 4 0}(\mathbf{6 1 \% )}$ \\
\hline
\end{tabular}

The IPA men's campus at Jeddah consists of $130 \mathrm{EFL}$ learners distributed into two levels: 55 Saudi EFL learners in the preparatory and 75 in the advanced. The survey questionnaires were distributed to the all population at IPA Jeddah men's campus. A total of 128 surveys were received and out of these 128 surveys, 3 were invalid and 5 were incomplete. A total of 120 valid and usable surveys were obtained from IPA Jeddah men's campus (see Table 4.4) and this representing $92 \%$ of the Saudi EFL learners at IPA Jeddah men's campus. The mean of age for learners surveyed at Jeddah men's campus was 21.33 years. As noticed, the Saudi EFL learners at Jeddah campus were highly willing in participating in the study among other IPA campuses 
Table 4.4 Jeddah Men's Campus Response Rate

\begin{tabular}{|l|c|c|c|}
\hline $\begin{array}{c}\text { English Language } \\
\text { Level }\end{array}$ & $\begin{array}{c}\text { Population (N) } \\
\text { (Number of } \\
\text { Learners) }\end{array}$ & $\begin{array}{c}\text { Number of } \\
\text { Distributed } \\
\text { Surveys }\end{array}$ & $\begin{array}{c}\text { Sample (n) } \\
\text { (Number of Valid } \\
\text { Surveys) }\end{array}$ \\
\hline Elementary & 55 & 55 & 48 \\
\hline Advanced & 75 & 75 & 72 \\
\hline Total & $\mathbf{1 3 0}$ & $\mathbf{1 3 0}$ & $\mathbf{1 2 0}(\mathbf{9 2 \% )}$ \\
\hline
\end{tabular}

Hence, the total sample of the study consists of 578

Saudi EFL learners from different IPA campuses. This sample contains 126 (22\%) Saudi Female EFL students and 452 (78\%) Saudi male EFL learners at IPA. Table 4.5 represents the population and the sample of the study.

Table 4.5 The Sample and Population of the Study

\begin{tabular}{|l|c|c|c|c|}
\hline \multicolumn{1}{|c|}{ IPA Campus } & Population & $\mathbf{n}$ & $\begin{array}{c}\text { \% of the } \\
\text { Campus } \\
\text { Population }\end{array}$ & $\begin{array}{c}\text { \% of the } \\
\text { Study Sample }\end{array}$ \\
\hline $\begin{array}{l}\text { Riyadh Men's } \\
\text { Campus }\end{array}$ & 950 & 192 & $20 \%$ & $33 \%$ \\
\hline $\begin{array}{l}\text { Riyadh } \\
\text { Women's } \\
\text { Campus }\end{array}$ & 155 & 126 & $81 \%$ & $21 \%$ \\
\hline $\begin{array}{l}\text { Dammam Men's } \\
\text { Campus }\end{array}$ & 230 & 140 & $60 \%$ & $24 \%$ \\
\hline $\begin{array}{l}\text { Jeddah Men's } \\
\text { Campus }\end{array}$ & 130 & 120 & $92 \%$ & $22 \%$ \\
\hline
\end{tabular}




\section{Findings of the Study}

Research Question 1

What are the Saudi EFL learners' attitudes toward CALL in general at the IPA?

Descriptive statistics were used to address this question. Namely, the mean value and standard deviation were conducted to measure Saudi EFL learners' attitudes toward CALL on a five-point Likert-type scale: Strongly Agree $=5$, Agree $=4$, Uncertain $=3$, Disagree $=2$, and Strongly Disagree $=1$. The higher the score, the more positive attitudes the learner holds toward CALL. All the survey scores were added together then divided by the number of the items to get the mean. Hence the attitudes are defined by the following number: 5 indicates highly positive attitude, 4 shows positive attitude, 3 indicates neutral attitudes (neither positive nor negative), 2 indicates negative attitudes, and finally 1 indicates very negative attitudes toward CALL. Each IPA campus's mean value and standard deviation will be represented below.

IPA Riyadh Men's Campus

The mean value of Saudi EFL learners' attitudes toward CALL at IPA Riyadh men's campus ranged from 2.5 to 4.83 (see 
Figure 4.1). The mean of Saudi EFL learners' attitudes toward CALL at IPA Riyadh men's campus was 3.61 and the standard deviation was 0.498 (see Table 4.6).

Figure 4.1 The Range of Learners' General Attitudes toward CALL at IPA Riyadh Men's Campus

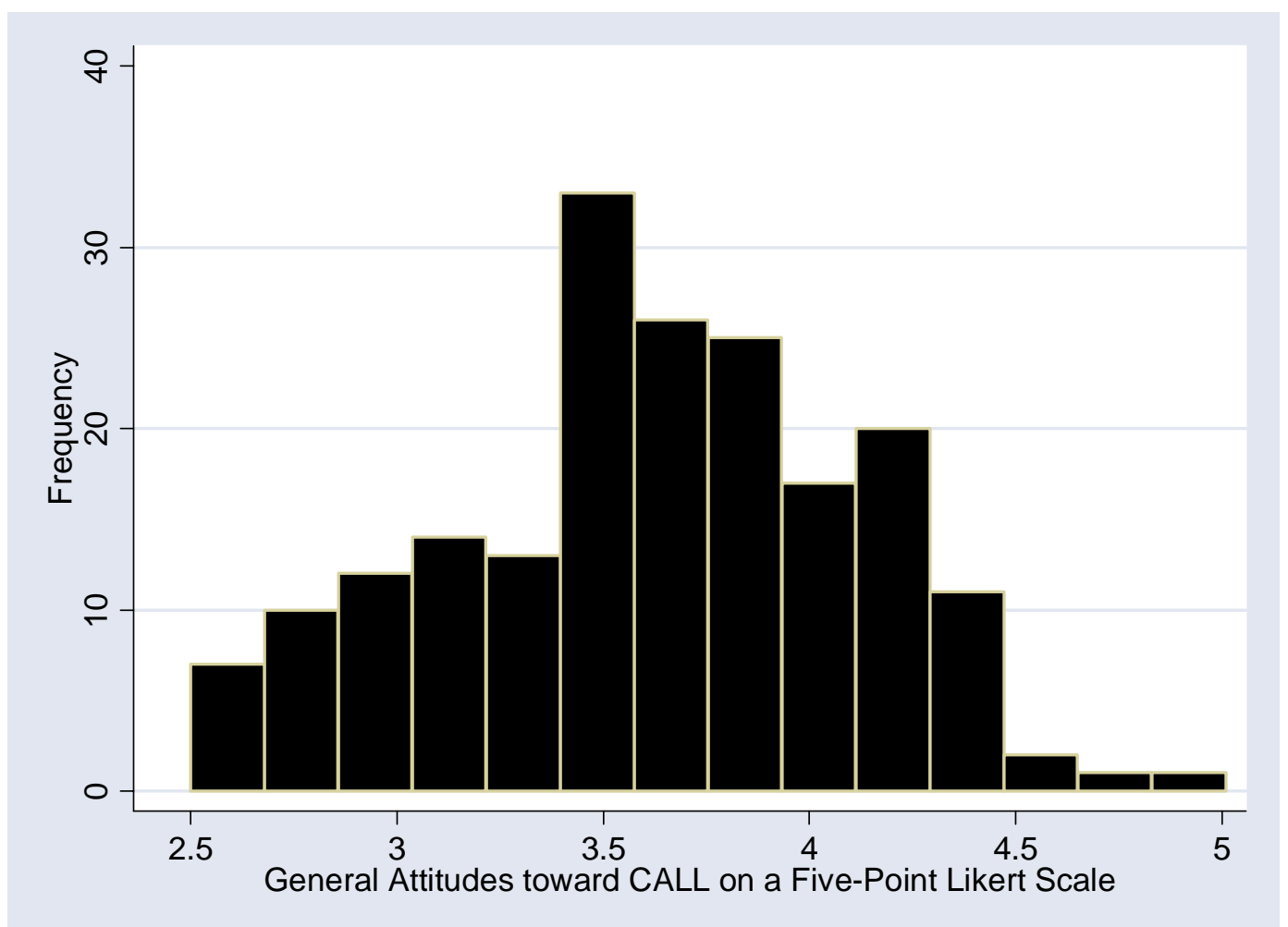

The mean value represented positive attitude toward CALL from 192 Saudi EFL learners surveyed at IPA Riyadh men's campus . 
Table 4.6 Descriptive Statistics of Learners' General Attitudes toward CALL at IPA Riyadh Men's Campus

\begin{tabular}{|l|c|c|c|c|}
\hline Variable & Mean & $\begin{array}{c}\text { Standard } \\
\text { Deviation }\end{array}$ & $\begin{array}{c}\text { Minimum } \\
\text { Score }\end{array}$ & $\begin{array}{c}\text { Maximum } \\
\text { Score }\end{array}$ \\
\hline $\begin{array}{l}\text { General } \\
\text { Attitudes } \\
\text { toward } \\
\text { CALL }\end{array}$ & 3.61 & .498 & 2.5 & 4.83 \\
\hline
\end{tabular}

IPA Riyadh Women's Campus

The mean of the Saudi women EFL students' attitudes toward CALL at IPA women's campus ranged from 3.13 to 4.8 . Figure 4.2 shows the range of attitudes of IPA Saudi EFL learners' attitudes toward CALL at IPA women's campus in Riyadh . 
Figure 4.2 The Range of Learners' General Attitudes toward CALL at IPA Riyadh Women's Campus

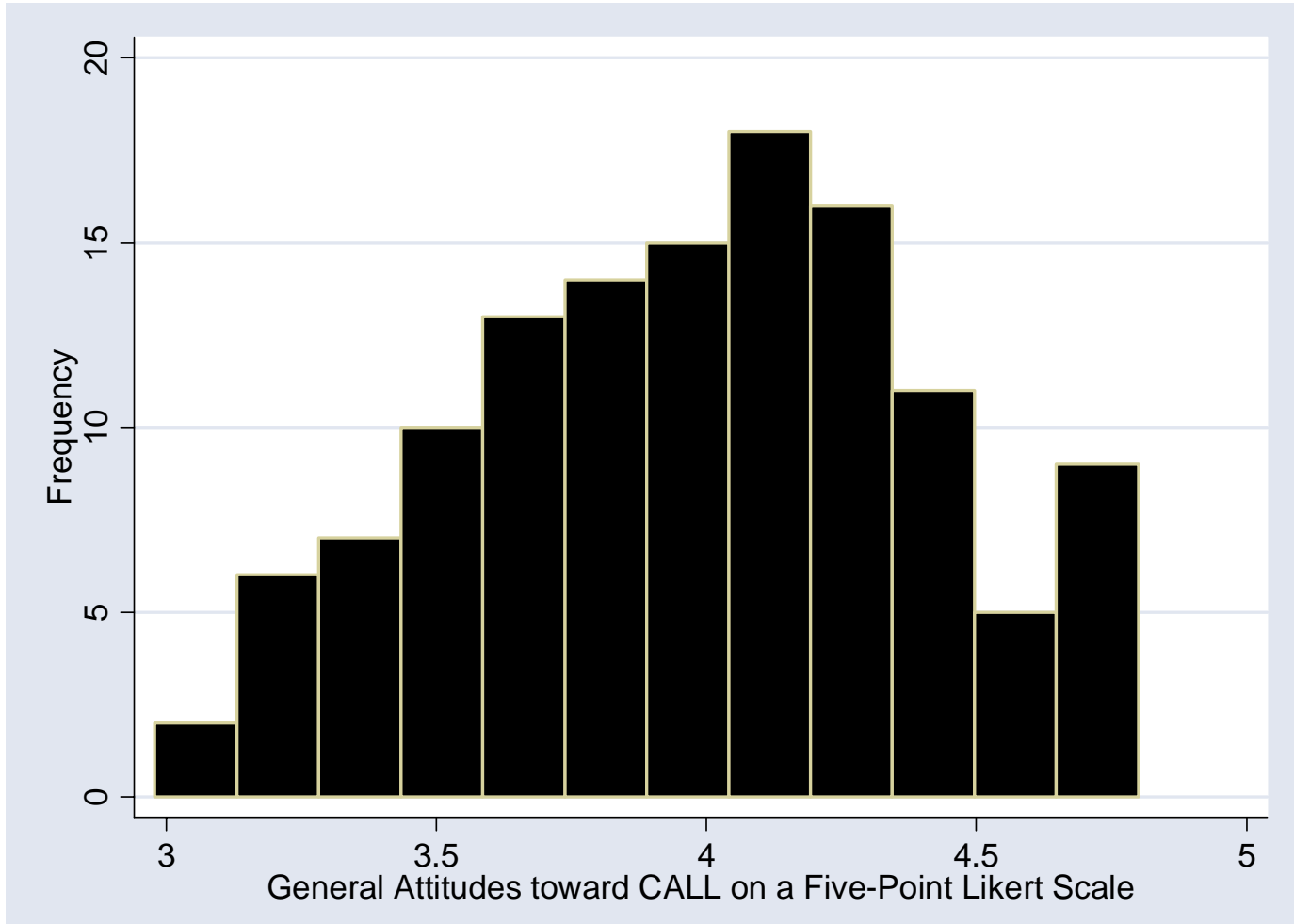

The mean of general attitudes value was 3.98 and the standard deviation was 0.415 (see Table 4.7). The mean value revealed that Saudi women EFL students hold positive attitudes toward the CALL.

Table 4.7 Descriptive Statistics of Learners' General Attitudes toward CALL at IPA Riyadh Women's Campus

\begin{tabular}{|l|c|c|c|c|}
\hline Variable & Mean & $\begin{array}{c}\text { Standard } \\
\text { Deviation }\end{array}$ & $\begin{array}{c}\text { Minimum } \\
\text { Score }\end{array}$ & $\begin{array}{c}\text { Maximum } \\
\text { Score }\end{array}$ \\
\hline $\begin{array}{l}\text { General } \\
\text { Attitudes } \\
\text { toward } \\
\text { CALL }\end{array}$ & 3.98 & .415 & 3.13 & 4.8 \\
\hline
\end{tabular}


IPA Dammam Men's Campus

The analysis of data showed that mean value of Saudi EFL students' attitudes toward CALL at IPA Dammam men's campus ranged from 2.36 to 4.9 (see Figure 4.3).

Figure 4.3 The Range of Learners' General Attitudes toward CALL at IPA Dammam Men's Campus

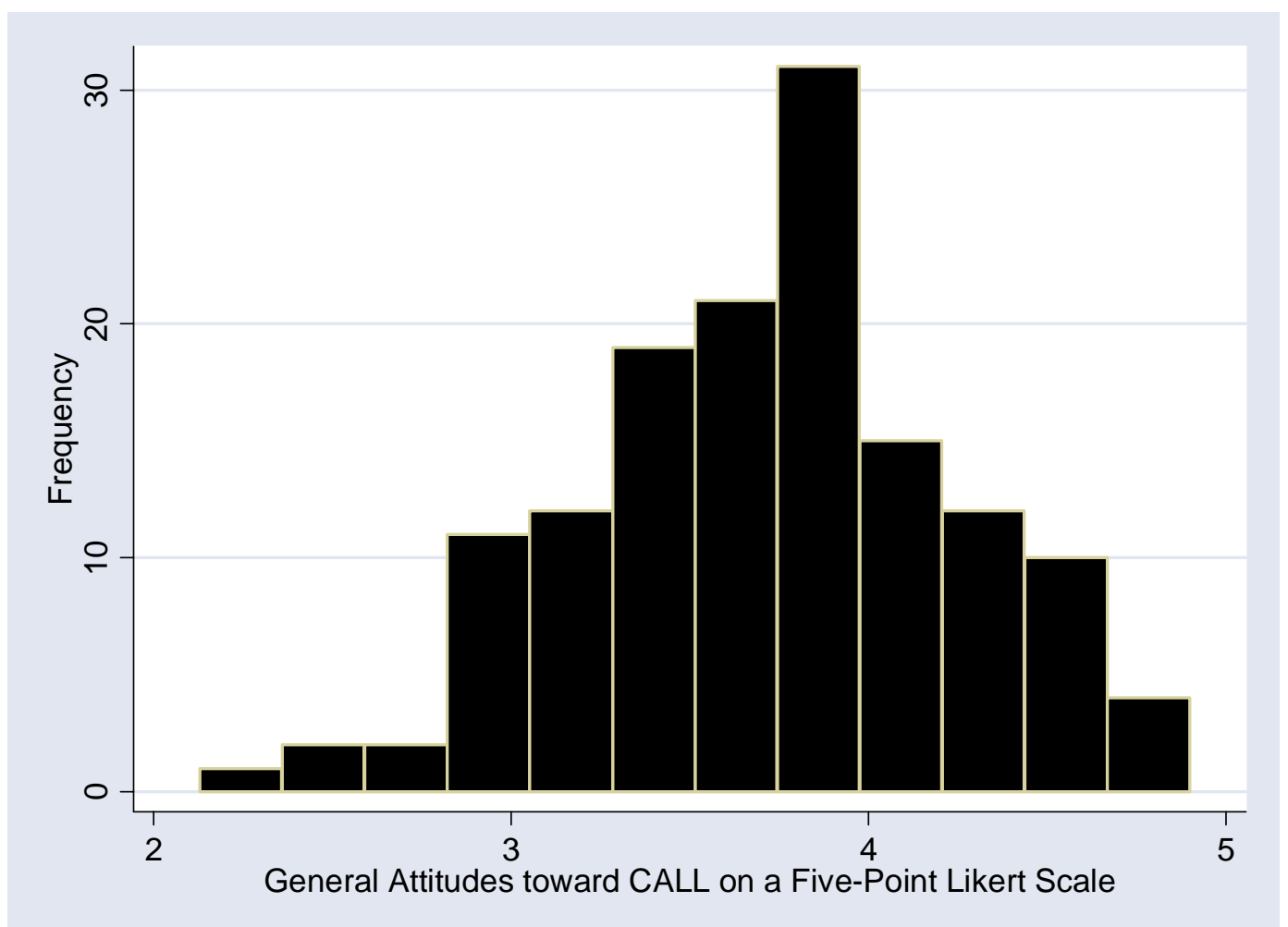

The mean value of Saudi EFL learners' attitudes toward CALL at IPA Dammam men's campus was 3.73 and the standard deviation was 0.526 (see Table 4.8). This showed that Saudi EFL learners at IPA Dammam campus hold positive attitudes toward the use of CALL in their English study program. 
Table 4.8 Descriptive Statistics of Learners' General Attitudes toward CALL at IPA Dammam Men's Campus

\begin{tabular}{|l|c|c|c|c|}
\hline Variable & Mean & $\begin{array}{c}\text { Standard } \\
\text { Deviation }\end{array}$ & $\begin{array}{c}\text { Minimum } \\
\text { Score }\end{array}$ & $\begin{array}{c}\text { Maximum } \\
\text { Score }\end{array}$ \\
\hline $\begin{array}{l}\text { General } \\
\text { At titudes } \\
\text { toward } \\
\text { CALL }\end{array}$ & 3.73 & .526 & 2.36 & 4.9 \\
\hline
\end{tabular}

\section{IPA Jeddah Men's Campus}

The analysis of data of IPA Jeddah men's campus showed that the lowest score of attitudes toward CALL was 2.66, whereas the highest was 4.66 (see Figure 4.4).

Figure 4.4 The Range of Learner's General Attitudes toward CALL at IPA Jeddah Men's Campus

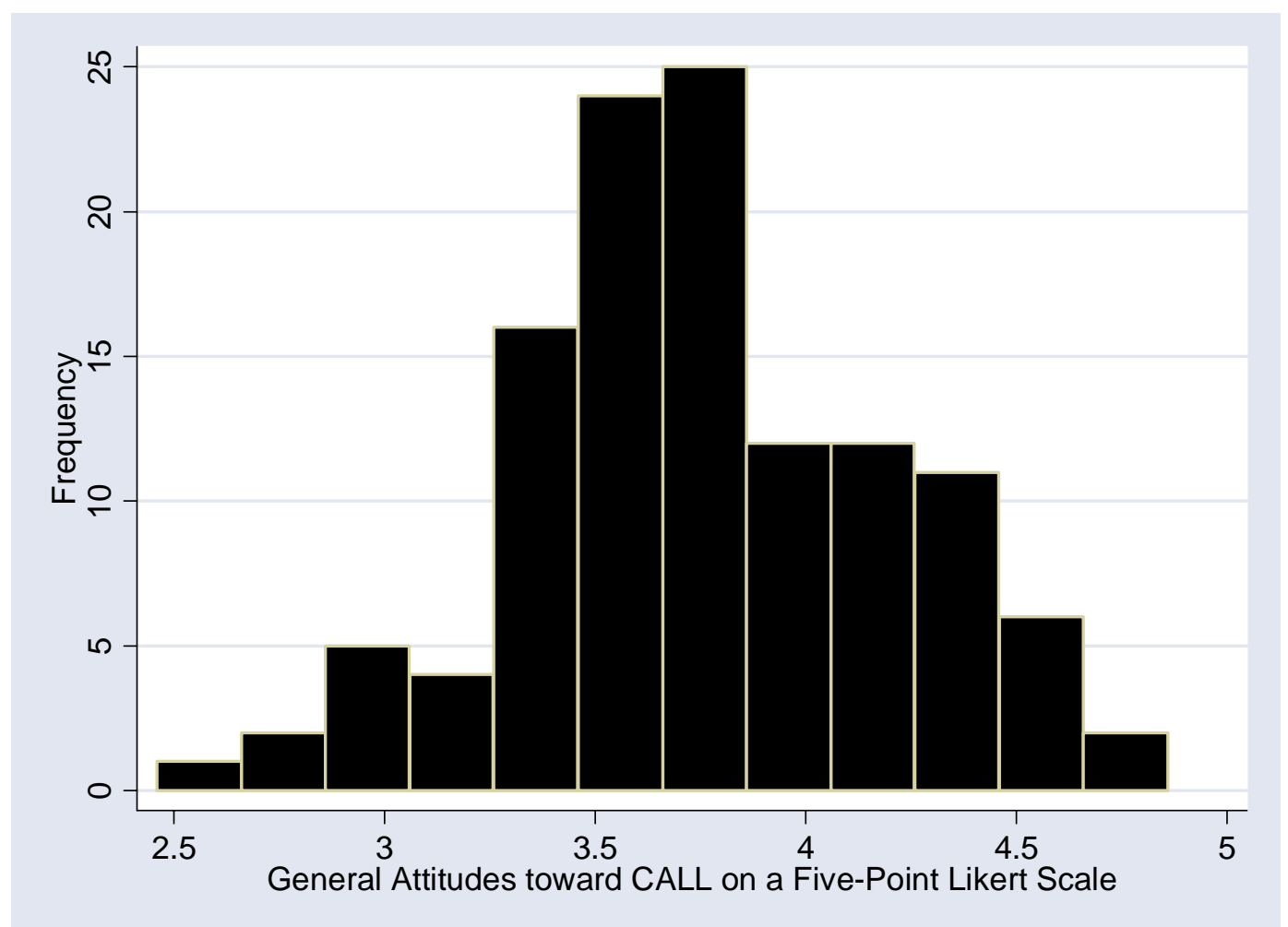


The mean value of Saudi EFL learners' attitudes toward CALL at IPA Jeddah men's campus was 3.75 and the standard deviation was 0.427 (see Table 4.9). The results showed positive attitudes toward CALL from 120 Saudi EFL learners surveyed at IPA Jeddah men's campus.

Table 4.9 Descriptive Statistics of Learners' General Attitudes toward CALL at IPA Jeddah Men's Campus

\begin{tabular}{|l|c|c|c|c|}
\hline Variable & Mean & $\begin{array}{c}\text { Standard } \\
\text { Deviation }\end{array}$ & $\begin{array}{c}\text { Minimum } \\
\text { Score }\end{array}$ & $\begin{array}{c}\text { Maximum } \\
\text { Score }\end{array}$ \\
\hline $\begin{array}{l}\text { General } \\
\text { Attitudes } \\
\text { toward } \\
\text { CALL }\end{array}$ & 3.75 & .427 & 2.66 & 4.66 \\
\hline
\end{tabular}

The Four IPA Campuses

The statistical analysis of the data obtained from 578 EFL learners (126 female learners and 452 male learners) at all IPA campuses showed that the mean value of attitudes toward CALL ranged from 2.36 to 4.9 (see Figure 4.5). 
Figure 4.5 The Range of Learners' General Attitudes toward CALL at the Four IPA Campuses

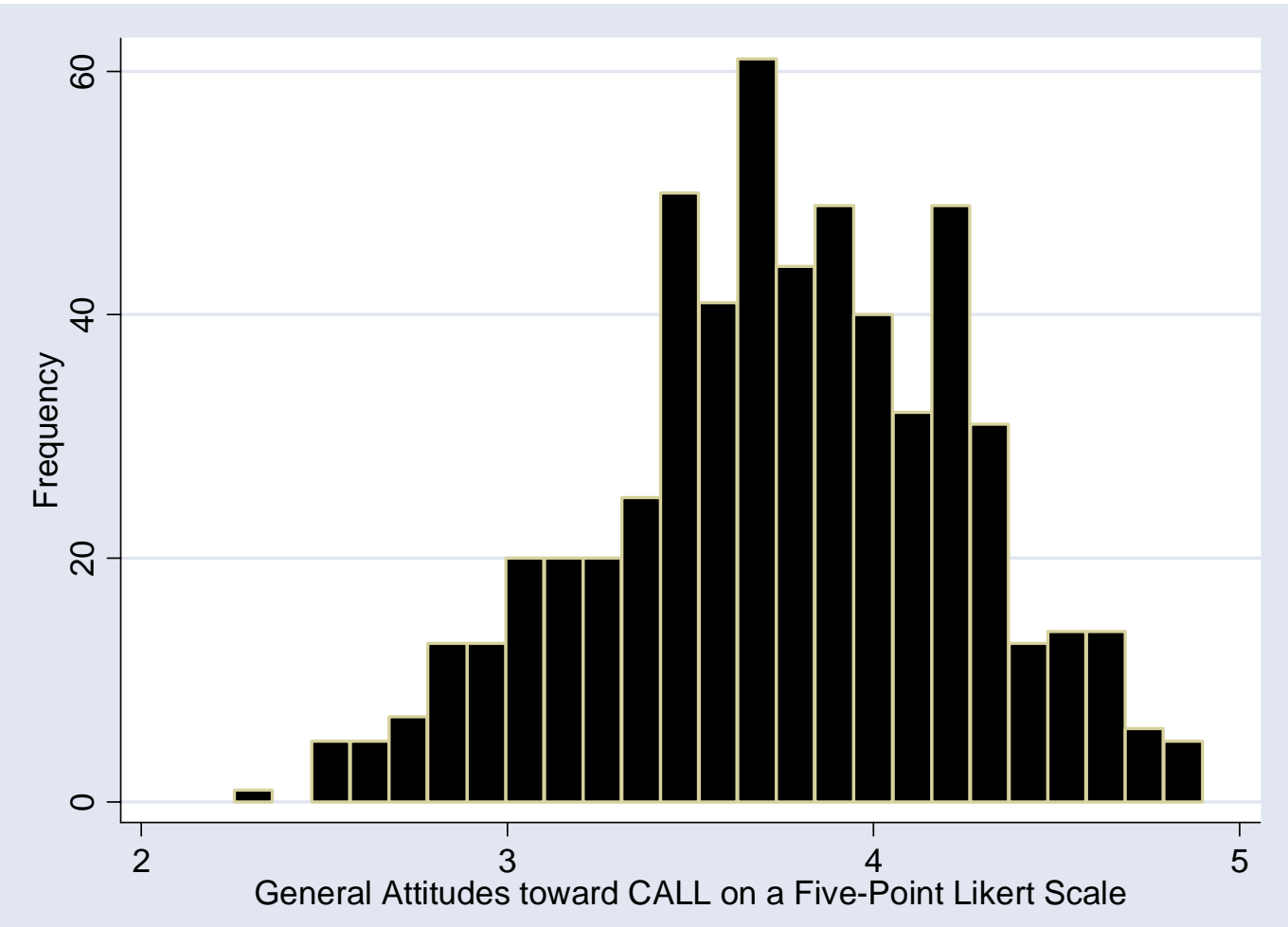

The mean value of attitudes toward CALL was 3.75 and the standard deviation was .0491 (see Table 4.10). This value showed that 578 surveyed Saudi EFL students in different four IPA campuses hold positive attitudes toward CALL in their IPA English language program. 
Table. 4.10 Descriptive Statistics of Learners' General Attitudes toward CALL at the Four IPA Campuses

\begin{tabular}{|l|c|c|c|c|}
\hline Variable & Mean & $\begin{array}{c}\text { Standard } \\
\text { Deviation }\end{array}$ & $\begin{array}{c}\text { Minimum } \\
\text { Score }\end{array}$ & $\begin{array}{c}\text { Maximum } \\
\text { Score }\end{array}$ \\
\hline $\begin{array}{l}\text { General } \\
\text { Attitudes } \\
\text { toward } \\
\text { CALL }\end{array}$ & 3.75 & .491 & 2.36 & 4.9 \\
\hline
\end{tabular}

Research Question 2

What are Saudi EFL learners' attitudes toward the CALL software used at the IPA?

This question was addressed by using a five-point Likert scale. The mean value and standard deviation were used to answer this question. As with the research question 1 , each IPA campus results will be given first and then the findings of all four campuses will be shown.

IPA Riyadh Men's Campus

The analysis of Riyadh Men's campus data showed that the lowest score of attitudes toward the CALL software at IPA was 1 and the highest was 5. The scores ranged from 1 (very negative attitudes) to 5 (very positive attitudes) and the mean value of Saudi EFL learners' attitudes toward the software was 3.23 and the standard deviation was 1.25 (see Table 4.11). 
Table 4.11 Descriptive Statistics of Learners' Attitudes toward the CALL Software at IPA Riyadh Men's Campus

\begin{tabular}{|l|c|c|c|c|}
\hline Variable & Mean & $\begin{array}{c}\text { Standard } \\
\text { Deviation }\end{array}$ & $\begin{array}{c}\text { Minimum } \\
\text { Score }\end{array}$ & $\begin{array}{c}\text { Maximum } \\
\text { Score }\end{array}$ \\
\hline $\begin{array}{l}\text { Attitudes } \\
\text { toward the } \\
\text { CALL } \\
\text { Software }\end{array}$ & 3.23 & 1.25 & 1 & 5 \\
\hline
\end{tabular}

The mean value showed that Saudi EFL learners have positive attitudes toward the New Dynamic English software used in the CALL labs at IPA Riyadh men's campus. Figure 4.6 shows the range of attitudes that learners at Riyadh men's campus expressed toward the CALL software.

Figure 4.6 The Range of Learners' Attitudes toward the CALL Software at IPA Riyadh Men's Campus

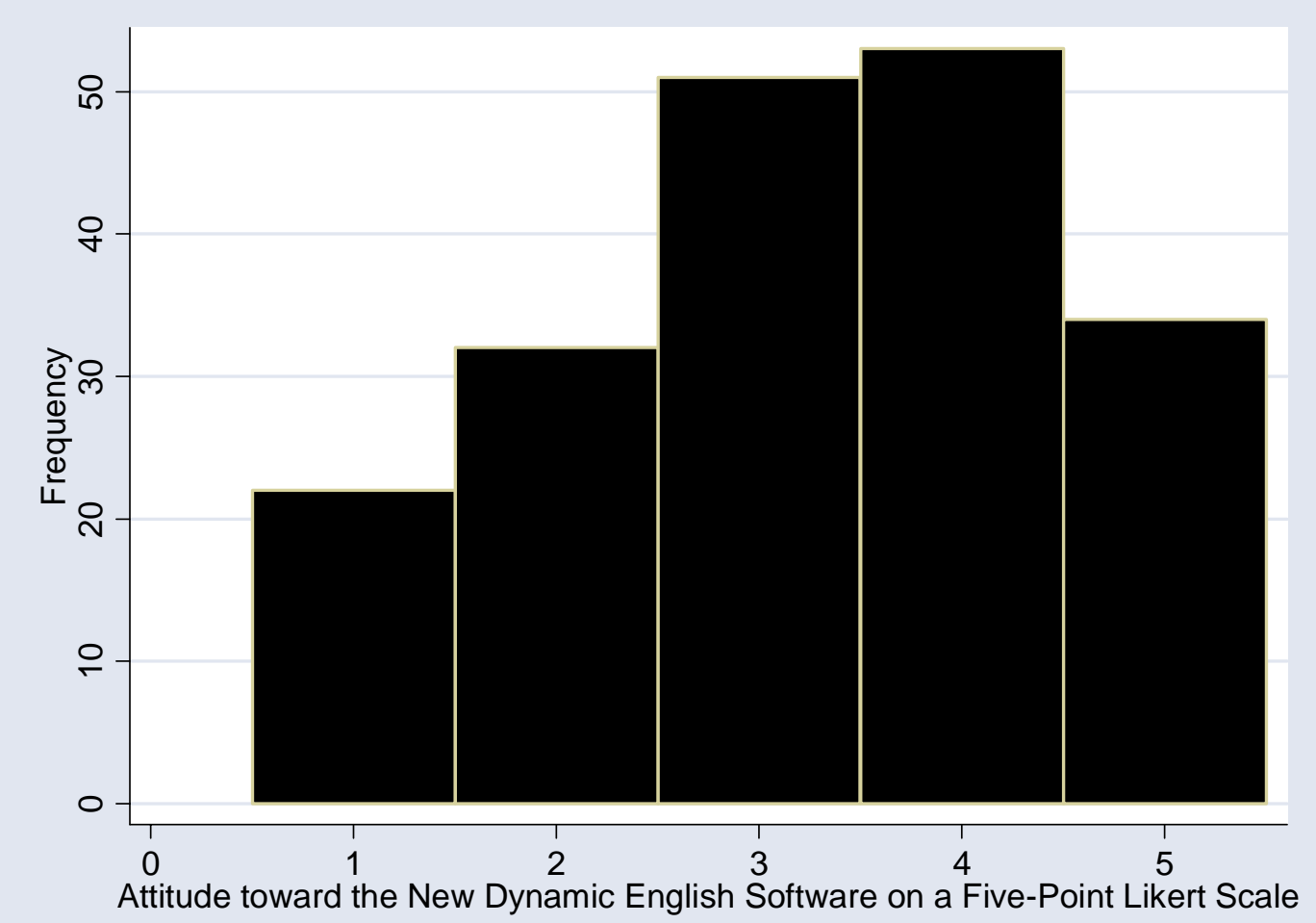


IPA Riyadh Women's Campus

Same as in Riyadh men's campus, the scored ranged from 1 to 5. The mean value of Saudi EFL women attitudes toward the software used at CALL labs at the women's campus was 3.26 with standard deviation of 1.03. Just as of the Riyadh men's campus, the lowest score was 1 and the highest was 5 (see Table 4.12).

Table 4.12 Descriptive Statistics of Learners' Attitudes toward the CALL Software at IPA Riyadh Women's Campus

\begin{tabular}{|l|c|c|c|c|}
\hline Variable & Mean & $\begin{array}{c}\text { Standard } \\
\text { Deviation }\end{array}$ & $\begin{array}{c}\text { Minimum } \\
\text { Score }\end{array}$ & $\begin{array}{c}\text { Maximum } \\
\text { Score }\end{array}$ \\
\hline $\begin{array}{l}\text { Attitudes } \\
\text { toward the } \\
\text { CALL } \\
\text { Software }\end{array}$ & 3.26 & 1.03 & 1 & 5 \\
\hline
\end{tabular}

The mean value revealed that Saudi female EFL learners' at the IPA have positive attitudes toward the New Dynamic English software used in the CALL in the IPA. Figure 4.7 explains the range of attitudes that IPA women learners hold toward the CALL software. 
Figure 4.7 The Range of Learners' Attitudes toward the CALL Software at IPA Riyadh Women's Campus

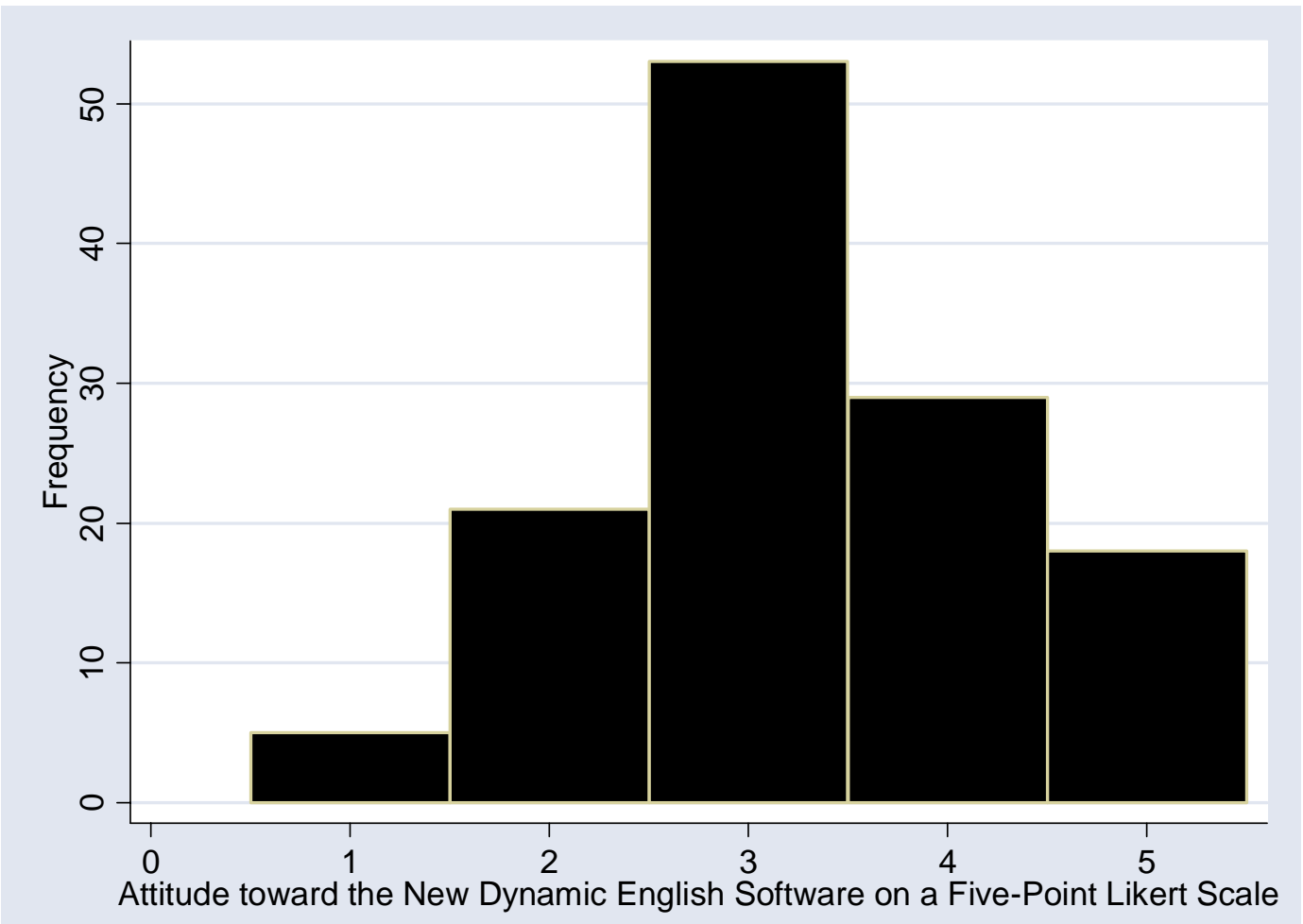

IPA Dammam Men's Campus

The analysis of data from 140 participants from the IPA Dammam men's branch showed that the mean of attitudes toward the CALL software at IPA was 3.53 and the standard deviation was 1.24 (see Table 4.13) and the scores ranged from very negative attitudes (score 1 ) to very positive attitudes ( score 5). 
Table 4.13 Descriptive Statistics of Learners' Attitudes toward the CALL Software at IPA Dammam Men's Campus

\begin{tabular}{|l|c|c|c|c|}
\hline Variable & Mean & $\begin{array}{c}\text { Standard } \\
\text { Deviation }\end{array}$ & $\begin{array}{c}\text { Minimum } \\
\text { Score }\end{array}$ & $\begin{array}{c}\text { Maximum } \\
\text { Score }\end{array}$ \\
\hline $\begin{array}{l}\text { Attitudes } \\
\text { toward the } \\
\text { CALL } \\
\text { Software }\end{array}$ & 3.53 & 1.24 & 1 & 5 \\
\hline
\end{tabular}

The mean value of 3.53 indicated the Saudi EFL learners' at IPA Dammam men's branch have positive attitudes toward the CALL software. Figure 4.8 explains the range of the expressed attitudes toward the CALL software by Dammam men learners. 
Figure 4.8 The Range of Learners' Attitudes toward the CALL Software at IPA Dammam Men's Campus

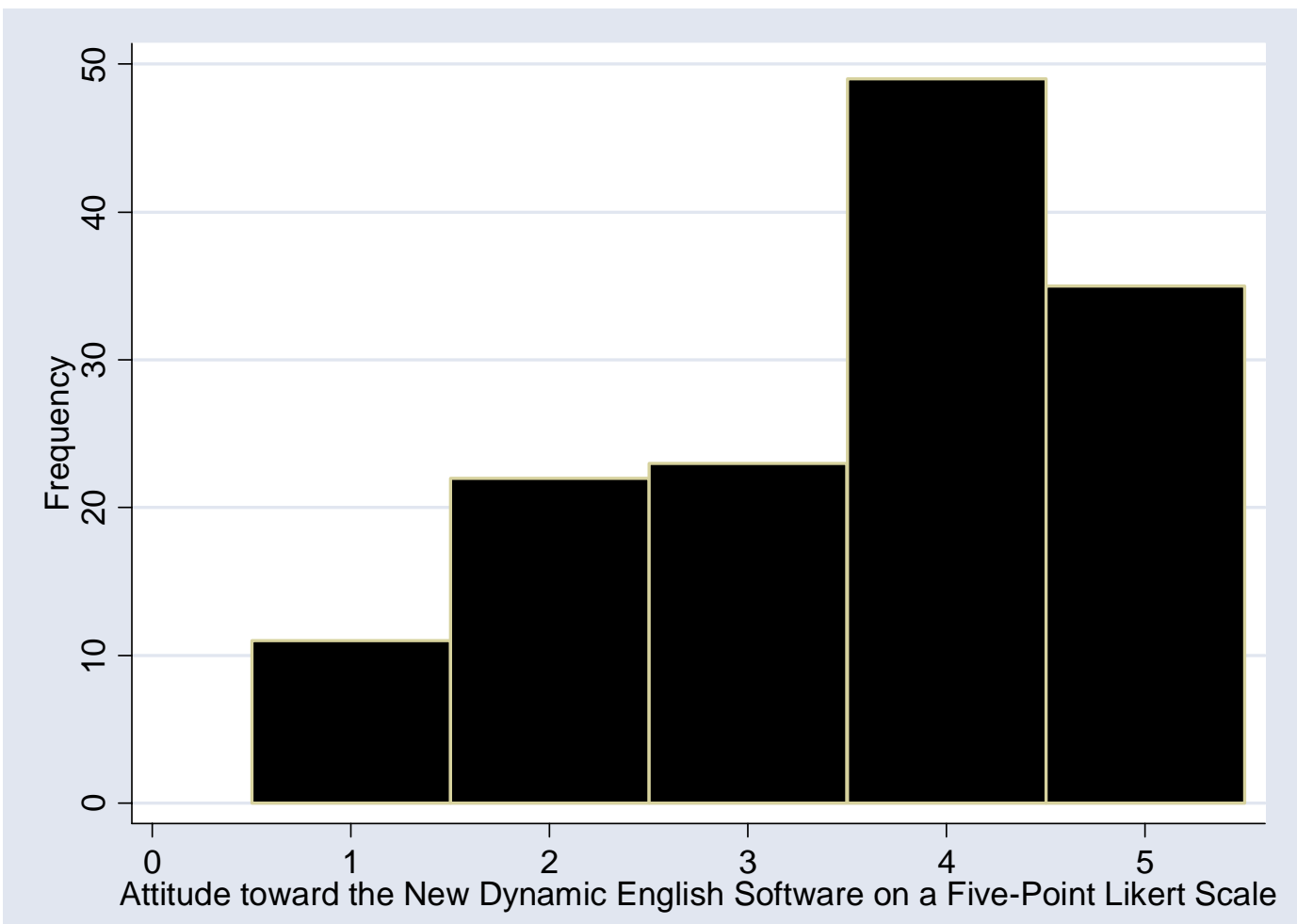

IPA Jeddah Men's Campus

The mean value of Saudi EFL learners' attitudes toward the CALL software was 3.51 and the standard deviation was 1.27. The scores ranged from 1 to 5 (see Table 4.14).

Table 4.14 Descriptive Statistics of Learners' Attitudes toward the CALL Software at the IPA Jeddah Men's Campus

\begin{tabular}{|l|c|c|c|c|}
\hline Variable & Mean & $\begin{array}{c}\text { Standard } \\
\text { Deviation }\end{array}$ & $\begin{array}{c}\text { Minimum } \\
\text { Score }\end{array}$ & $\begin{array}{c}\text { Maximum } \\
\text { Score }\end{array}$ \\
\hline $\begin{array}{l}\text { Attitudes } \\
\text { toward the } \\
\text { CALL } \\
\text { Software }\end{array}$ & 3.51 & 1.27 & 1 & 5 \\
\hline
\end{tabular}


The mean value of learners' attitudes toward CALL at Jeddah branch showed that there are satisfactory attitudes toward the CALL software. Figure 4.9 shows the range of learners' attitudes toward the CALL software.

Figure 4.9 The Range of Learners' Attitudes toward the CALL Software at IPA Jeddah Men's Campus

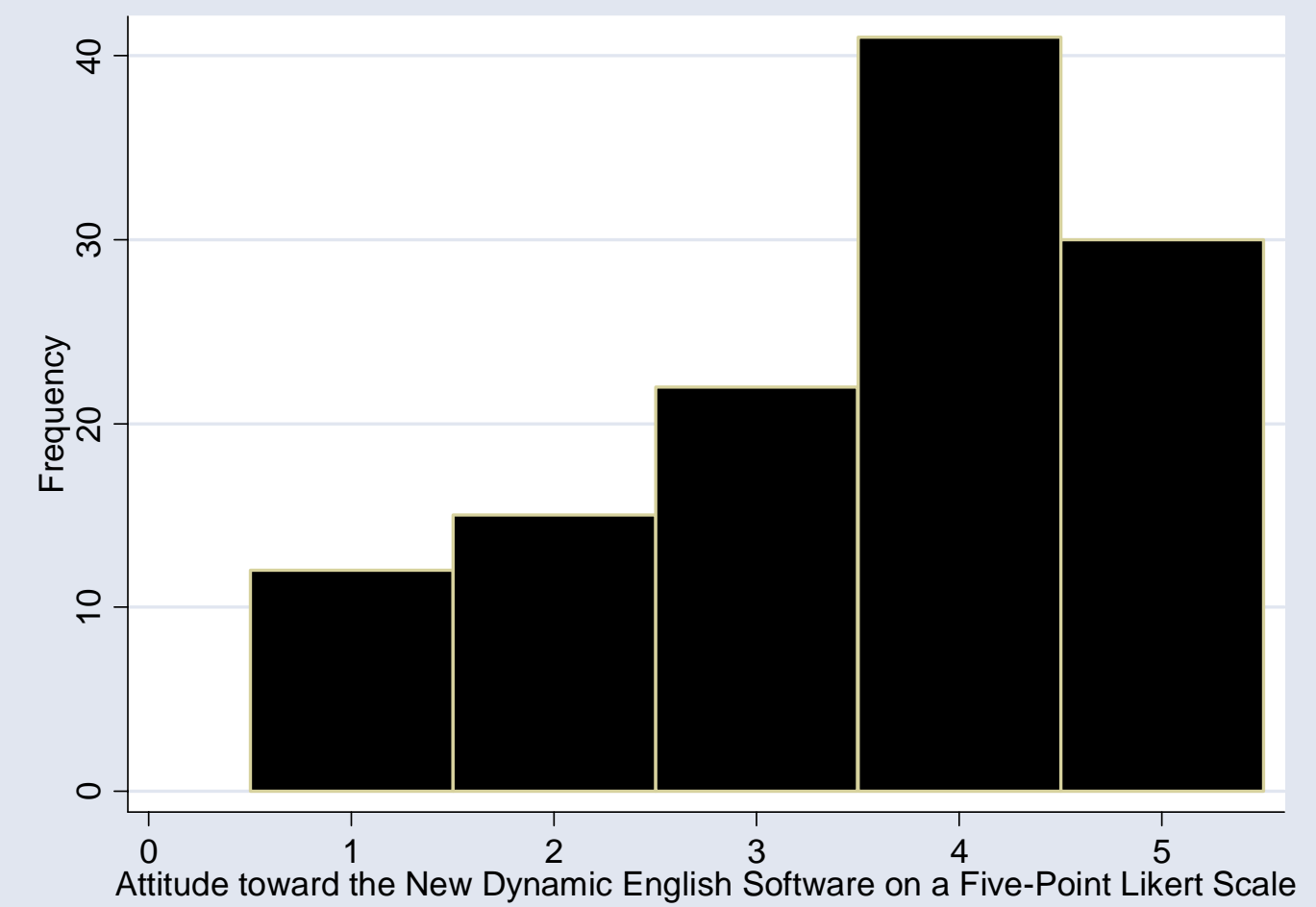

The Four IPA Campuses

The combination of all four IPA campuses samples resulted in a mean value of 3.37 of attitudes toward the CALL software and a standard deviation of 1.21 (see Table 4.15). 
Table. 4.15 Descriptive Statistics of Learners' Attitudes toward the CALL Software at the Four IPA Campuses

\begin{tabular}{|l|c|c|c|c|}
\hline Variable & Mean & $\begin{array}{c}\text { Standard } \\
\text { Deviation }\end{array}$ & $\begin{array}{c}\text { Minimum } \\
\text { Score }\end{array}$ & $\begin{array}{c}\text { Maximum } \\
\text { Score }\end{array}$ \\
\hline $\begin{array}{l}\text { Attitudes } \\
\text { toward the } \\
\text { CALL } \\
\text { Software }\end{array}$ & 3.37 & 1.21 & 1 & 5 \\
\hline
\end{tabular}

Figure 4.10 shows the range of attitudes toward the CALL software. Hence, the mean value represented positive attitude toward the CALL software at the IPA from the sample of 578 Saudi EFL learners from different IPA campuses.

Figure 4.10 The Range of Learners' Attitudes toward the CALL Software at the Four IPA Campuses

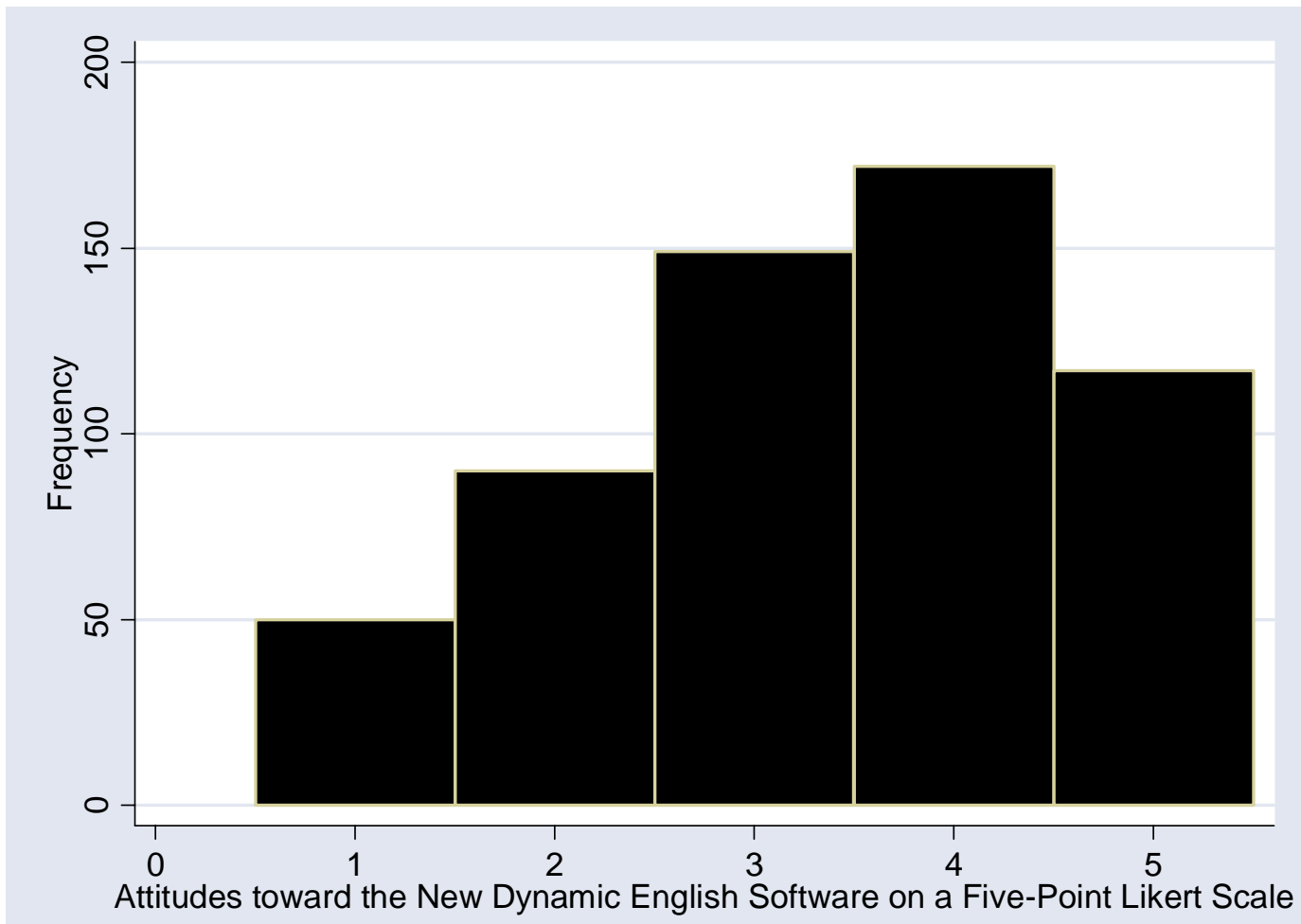


Research Question 3

What are the differences between Saudi EFL learners' attitudes toward CALL at the IPA based on their years of English learning?

Null hypothesis 3: There is no statistically significant difference among Saudi EFL learners' attitudes toward CALL at the IPA based on their years of English learning.

Inferential statistics were used to address this question. Namely, a regression model was conducted to address the question of whether or not the learners' years of English learning can be used to predict Saudi EFL learners' attitudes toward CALL at the IPA or explain some of the variance among Saudi EFL learners' attitudes. The information of the years of English study of each learner at different IPA campuses was obtained from the demographic questionnaire then linked to the student's general attitudes toward CALL.

IPA Riyadh Men's Campus

The analysis of data from IPA men's campus at Riyadh showed that there was no significant difference in Saudi EFL learners attitudes toward CALL based on their years of English learning $(p=0.438)$ (see Table 4.16) with an adjusted 
R-squared of 0.0375 . Based on this result, years of English learning cannot be used as a predictor of the Saudi EFL learners' attitudes toward CALL at the IPA Riyadh men's campus. Hence, the researcher failed to reject the null hypothesis stating that there is no statistically significant difference among Saudi EFL learners' attitudes toward CALL at the IPA based on their years of English learning for the Riyadh men's campus.

Table 4.16 Regression Model of Learners' Attitudes toward CALL Based on Their Years of English Learning at Riyadh Men's Campus

\begin{tabular}{|c|c|c|c|c|c|}
\hline Attitudes toward CALL & Coef. & $\mathbf{t}$ & $\begin{array}{l}\mathrm{P}>\mathrm{I} \\
\mathrm{t}\end{array}$ & R-squared & $\begin{array}{l}\text { Adjusted } \\
\text { R-squared }\end{array}$ \\
\hline Years of English Study & -.0103631 & $\underline{-0.78}$ & 0.438 & \multirow{6}{*}{0.0627} & \multirow{6}{*}{$\underline{0.0375}$} \\
\hline Computer Ownership & .002594 & 0.03 & 0.977 & & \\
\hline $\begin{array}{l}\text { Years of Computer } \\
\text { Experience }\end{array}$ & .0018478 & 0.16 & 0.871 & & \\
\hline $\begin{array}{l}\text { Hours of Daily Computer } \\
\text { Use }\end{array}$ & .0501016 & 2.19 & 0.030 & & \\
\hline $\begin{array}{l}\text { Self-Evaluation of } \\
\text { Computer Experience }\end{array}$ & .079108 & 1.95 & 0.052 & & \\
\hline Cons & 3.305895 & 22.13 & 0.000 & & \\
\hline
\end{tabular}

$* \underline{p}<.05$

IPA Riyadh Women's Campus

The prediction model at the IPA Riyadh women's branch showed that there was statistically no significant differences based on years of English study were found $(p=$ 
$\odot .365$ ) (see Table 4.17). This model explained ( $\odot .0471$ ) of the variance in attitudes toward CALL (Adjusted Rsquared $=0.0471$ ). The years of English learning of Saudi women EFL learners at the IPA cannot explain the variance in attitudes toward the use of CALL in the English language program. The researcher failed to reject the null hypothesis of research question 3 stating that there is no statistically significant difference among Saudi EFL learners' attitudes toward CALL at the IPA based on their years of English learning for the Riyadh women's campus.

Table 4.17 Regression Model of Learners' Attitudes toward CALL Based on Their Years of English Learning at Riyadh Women's Campus

\begin{tabular}{|c|c|c|c|c|c|}
\hline Attitudes toward CALL & Coef. & $\mathbf{t}$ & $\begin{array}{c}\mathrm{P}>\mathrm{I} \\
\mathrm{t}\end{array}$ & R-squared & $\begin{array}{l}\text { Adjusted } \\
\text { R-squared }\end{array}$ \\
\hline Years of English Study & $.00 \overline{\overline{9}} 991$ & $\underline{-0.91}$ & $\underline{0.365}$ & \multirow{6}{*}{$\underline{0.0853}$} & \multirow{6}{*}{$\underline{0.0471}$} \\
\hline Computer Ownership & .0014148 & 0.01 & 0.988 & & \\
\hline $\begin{array}{l}\text { Years of Computer } \\
\text { Experience }\end{array}$ & .0034195 & 0.24 & 0.812 & & \\
\hline Hours of Daily Computer Use & .0326234 & 1.31 & 0.192 & & \\
\hline $\begin{array}{l}\text { Self-Evaluation of Computer } \\
\text { Experience }\end{array}$ & .0926057 & 1.62 & 0.108 & & \\
\hline Cons & 3.669607 & 21.51 & 0.000 & & \\
\hline
\end{tabular}

${ }^{*} \mathrm{p}<.05$

IPA Dammam Men's Campus

There were statistically no significant differences in Saudi EFL learners' attitudes toward CALL at the IPA Dammam 
men's campus based on the number of years they have spent learning English $(p=0.404)$. The regression model for the IPA Dammam men's campus explained 0.1682 of the variance in Saudi EFL learners' attitudes toward CALL (see Table 4.18). The null hypothesis 3 that states that there is no statistically significant difference among Saudi EFL learners' attitudes toward CALL at the IPA based on their years of English learning was true and the researcher failed to reject it for the Dammam men's campus.

Table 4.18 Regression Model of Learners' Attitudes toward CALL Based on Their Years of English Learning at Dammam Men's Campus

\begin{tabular}{|c|c|c|c|c|c|}
\hline Attitudes toward CALL & Coef. & $\mathrm{t}$ & $\begin{array}{ll}P> & I \\
t & \end{array}$ & R-squared & $\begin{array}{l}\text { Adjusted } \\
\text { R-squared }\end{array}$ \\
\hline Years of English Study & .013227 & $\underline{0.84}$ & 0.404 & \multirow{6}{*}{$\underline{0.1981}$} & \multirow{6}{*}{$\underline{0.1682}$} \\
\hline Computer Ownership & .0425385 & 0.36 & 0.716 & & \\
\hline $\begin{array}{l}\text { Years of Computer } \\
\text { Experience }\end{array}$ & - . 0183714 & -1.23 & 0.222 & & \\
\hline $\begin{array}{l}\text { Hours of Daily Computer } \\
\text { Use }\end{array}$ & .0635443 & 2.99 & 0.003 & & \\
\hline $\begin{array}{l}\text { Self-Evaluation of } \\
\text { Computer Experience }\end{array}$ & .1726566 & 2.49 & 0.014 & & \\
\hline Cons & 2.974397 & 15.42 & 0.000 & & \\
\hline
\end{tabular}

* $\underline{p}<.05$

IPA Jeddah Men's Campus

Statistically no significant differences were found in Saudi EFL learners' attitudes toward CALL at the IPA Jeddah 
men's campus $(p=0.665)$. The IPA Jeddah men's campus's model explains 0.0506 of the variance among students' attitudes toward CALL (see Table 4.19). Based on these findings, the researcher failed to reject the null hypothesis of research question 3 that says there is no statistically significant difference among Saudi EFL learners' attitudes toward CALL at the IPA based on their years of English learning for the Jeddah men's campus.

Table 4.19 Regression Model of Learners' Attitudes toward CALL Based on Their Years of English Learning at Jeddah Men's Campus

\begin{tabular}{|c|c|c|c|c|c|}
\hline Attitudes toward CALL & Coef. & $\mathbf{t}$ & $\begin{array}{l}\mathrm{P}>\mathrm{I} \\
\mathrm{t}\end{array}$ & R-squared & $\begin{array}{l}\text { Adjusted } \\
\text { R-squared }\end{array}$ \\
\hline Years of English Study & .0071803 & 0.43 & 0.665 & \multirow{6}{*}{0.0905} & \multirow{6}{*}{0.0506} \\
\hline Computer Ownership & .1121716 & 1.15 & 0.252 & & \\
\hline $\begin{array}{l}\text { Years of Computer } \\
\text { Experience }\end{array}$ & - . 0019778 & -0.12 & 0.909 & & \\
\hline $\begin{array}{l}\text { Hours of Daily Computer } \\
\text { Use }\end{array}$ & - . 0159893 & -0.70 & 0.482 & & \\
\hline $\begin{array}{l}\text { Self-Evaluation of } \\
\text { Computer Experience }\end{array}$ & .151935 & 2.53 & 0.013 & & \\
\hline Cons & 3.193344 & 17.46 & 0.000 & & \\
\hline
\end{tabular}

$* \underline{p}<.05$

Research Question 4

What are the differences between Saudi EFL learners' attitudes toward CALL at the IPA based on their computer knowledge? 
Null hypothesis 4: There is no statistically significant difference among Saudi EFL learners' attitudes toward CALL at the IPA based on their computer knowledge.

Same as the research question 3, the regression model was used to answer this question. Learners' computer knowledge was defined in this study by the combination of ownership of computers (having a personal computer), years of computer experience (number of years that a learners has used computers), hours of daily use (daily exposure to computers in hours), and self-evaluation of computer experience (1 to 5 scale which 1 indicating poor experience with computers and 5 indicating a high level of computer experience). Each of these variables was addressed separately in the model to see the significance that each has on the learners' attitudes toward CALL at the IPA. Then, factor analysis was used to measure the affect of all these variables on Saudi EFL learners' attitudes toward CALL at the four IPA campuses. Factor analysis is a statistical technique used to put various measures into one value (Field, 2000). It is also used to analyze the interrelationships among several different variables and to explain these variables in terms of their common underlying dimensions or factors (Hair, Black, Babin, Anderson, \& Tatham, 2005). Factor analysis was 
used to either reject or fail to reject the null hypothesis of question 4 .

IPA Riyadh Men's Campus

The first variable in computer knowledge was computer ownership. The analysis of data showed that computer ownership did not have a statistically significant effect on Saudi EFL learners attitudes toward CALL at the Riyadh men's campus $(p=0.977)$. In addition, statistically no significant differences were found based on years of computer experience $(p=0.16)$. However, hours of daily computer use represented a statistically significant difference in Saudi EFL learners' attitudes toward CALL $(p=0.030)$. That is, the more the hours learners use computers, the more positive attitudes they hold toward CALL. The last component of computer knowledge was self-evaluation of computer knowledge. The regression models showed that self-evaluation of computer experience had a significant effect on Saudi EFL learners' attitudes toward CALL $(p=.052)$. This means that when a learner believes that s/he has significant experiences with computer, s/he will hold a positive attitude toward CALL. As seen in Table 4.20, the regression model of Riyadh men's campus explained 0.0375 of the variance in attitudes toward CALL among Saudi EFL learners. 
Table 4.20 Regression Model of Learners' Attitudes toward CALL Based on Their Computer Knowledge at Riyadh Men's Campus

\begin{tabular}{|c|c|c|c|c|c|}
\hline Attitudes toward CALL & Coef. & $\mathrm{t}$ & $\begin{array}{l}\text { P> } \\
t \quad 1\end{array}$ & R-squared & $\begin{array}{l}\text { Adjusted } \\
\text { R-squared }\end{array}$ \\
\hline Computer Ownership & .002594 & $\underline{0.03}$ & $\underline{0.977}$ & \multirow{6}{*}{$\underline{0.0627}$} & \multirow{6}{*}{$\underline{0.0375}$} \\
\hline $\begin{array}{l}\text { Years of Computer } \\
\text { Experience }\end{array}$ & .0018478 & $\underline{0.16}$ & $\underline{0.871}$ & & \\
\hline $\begin{array}{l}\text { Hours of Daily Computer } \\
\text { Use }\end{array}$ & .0501016 & $\underline{2.19}$ & $\underline{0.030}$ & & \\
\hline $\begin{array}{l}\text { Self-Evaluation of } \\
\text { Computer Experience }\end{array}$ & .079108 & $\underline{1.95}$ & $\underline{0.052}$ & & \\
\hline Years of English Study & -.0103631 & -0.78 & 0.438 & & \\
\hline Cons & 3.305895 & 22.13 & 0.000 & & \\
\hline
\end{tabular}

${ }^{*} \underline{p}<.05$

The researcher conducted a factor analysis for the computer knowledge variable from the four variables. Then another regression model was also conducted (see Table 4.21). The findings showed that computer knowledge of subjects had a high statistically significant effect on their attitudes toward CALL $(p=0.003)$ and the regression model represented 0.0351 of the variance in learners' attitudes toward CALL. These findings showed that the more knowledge of computer learners have, the more positive attitudes they hold toward CALL. Based on these findings, the null hypothesis 4 stating that there is no statistically significant difference among Saudi EFL learners' attitudes toward CALL at the IPA based on their computer knowledge was rejected by the researcher for the Riyadh men's campus. 
Table 4.21 Regression Model of Learners' Attitudes toward CALL Based on Their Computer Knowledge at Riyadh Men's Campus after Conducting Factor Analysis

\begin{tabular}{|c|c|c|c|c|c|}
\hline Attitudes toward CALL & Coef. & $\mathbf{t}$ & $\begin{array}{cl}P> & \text { I } \\
t & \text { I }\end{array}$ & R-squared & $\begin{array}{l}\text { Adjusted } \\
\text { R-squared }\end{array}$ \\
\hline $\begin{array}{l}\text { Computer Knowledge } \\
\text { (Factor Analysis) }\end{array}$ & .1053756 & $\underline{2.96}$ & 0.003 & \multirow{3}{*}{0.0452} & \multirow{3}{*}{0.0351} \\
\hline Years of English Study & -.0097656 & -0.73 & 0.463 & & \\
\hline Cons & 3.680284 & 37.99 & 0.000 & & \\
\hline
\end{tabular}

$* \underline{p}<.05$

IPA Riyadh Women's Campus

The regression model for the Riyadh women's campus (see Table 4.22) showed that there were no significant differences found in Saudi women EFL learners' attitudes toward CALL based on their ownership of computers $(p=0.988)$. As for the years of computer experience, there was no significant differences found $(p=0.812)$. In addition, the daily use of computer, in hours, that Saudi women EFL learners spend on computers did not statistically have a significant difference in their attitudes toward CALL. The last component of computer knowledge, the self evaluation of computer experience also did not have a statistically significant difference in women's attitudes toward CALL. This regression model explained 0.471 of the variance in Saudi women EFL 
students' attitudes toward CALL at Riyadh women's campus for the Riyadh women campus.

Table 4.22 Regression Model of Learners' Attitudes toward CALL Based on Their Computer Knowledge at Riyadh Women's Campus

\begin{tabular}{|c|c|c|c|c|c|}
\hline Attitudes toward CALL & coef. & $\mathrm{t}$ & $\begin{array}{cc}P> & \text { I } \\
t & \text { l }\end{array}$ & R-squared & $\begin{array}{c}\text { Adjusted } \\
\text { R-squared }\end{array}$ \\
\hline Computer Ownership & .0014148 & 0.01 & 0.988 & \multirow{6}{*}{$\underline{0.0853}$} & \multirow{6}{*}{0.0471} \\
\hline $\begin{array}{l}\text { Years of Computer } \\
\text { Experience } \\
\end{array}$ & .0034195 & $\underline{0.24}$ & $\underline{0.812}$ & & \\
\hline $\begin{array}{l}\text { Uours of Daily Computer } \\
\text { Use }\end{array}$ & .0326234 & $\underline{1.31}$ & 0.192 & & \\
\hline$\overline{\overline{\text { Self-Evaluation of }}} \overline{\text { Computer Experience }}$ & .0926057 & $\underline{1.62}$ & 0.108 & & \\
\hline Years of English Study & -.0097991 & -0.91 & 0.365 & & \\
\hline Cons & 3.669607 & 21.51 & 0.000 & & \\
\hline
\end{tabular}

${ }^{*} \mathrm{p}<.05$

After conducting the factor analysis of computer experience variable, Saudi women EFL learners' computer knowledge had a significant difference in modifying their attitudes toward CALL $(p=.003)$ (see Table 4.23). This means that the more computer knowledge Saudi women EFL learners at IPA have, the more positive attitude they show toward CALL. Table 4.23 shows that this regression model explains 0.0596 of the variance of attitudes toward CALL that Saudi women EFL learners hold. Hence, the null hypothesis of research question 4 was rejected for the IPA Riyadh women's campus. 
Table 4.23 Regression Model of Learners' Attitudes toward CALL Based on Their Computer Knowledge at Riyadh Women's Campus after Conducting Factor Analysis

\begin{tabular}{|l|c|c|c|c|c|}
\hline Attitudes toward CALL & Coef. & t & $\begin{array}{c}\text { P> I } \\
\text { t I }\end{array}$ & R-squared & $\begin{array}{c}\text { Adjusted } \\
\text { R-squared }\end{array}$ \\
\cline { 1 - 4 } $\begin{array}{l}\text { Computer Knowledge } \\
\text { (Factor Analysis) }\end{array}$ & $\underline{.1120047}$ & $\underline{3.08}$ & $\underline{0.003}$ & & \\
\cline { 1 - 4 } Years of English Study & -.0107088 & -1.00 & 0.318 & \multirow{2}{*}{0.0746} & $\underline{0.0596}$ \\
\cline { 1 - 4 } Cons & 4.066464 & 43.36 & 0.000 & & \\
\hline
\end{tabular}

* $\underline{p}<.05$

IPA Dammam Men's Campus

The analysis of IPA Dammam participants' data showed that computer ownership had no statistically significant difference in their attitudes toward CALL $(p=0.7160)$. Computer experience also had no statistically significant difference in learners' attitudes toward CALL $(p=0.222)$. As for hours of daily use, the regression model showed that hours of daily use component had a strong significant difference in attitudes toward CALL $(p=0.003)$. Finally, the self-evaluation of computer experience also had a significant difference in Saudi EFL learners' attitudes toward CALL at Dammam campus $(p=0.014)$ ( see Table 4.24). This regression model explained 0.1682 of the variance in learners' attitudes toward CALL at Dammam men's campus. 
Table 4.24 Regression Model of Learners' Attitudes toward CALL Based on Their Computer Knowledge Dammam Men's Campus

\begin{tabular}{|c|c|c|c|c|c|}
\hline Attitudes toward CALL & Coef. & $\mathbf{t}$ & \begin{tabular}{c|c|}
$P>$ & $I$ \\
$t$ & $\mid$
\end{tabular} & R-squared & $\begin{array}{l}\text { Adjusted } \\
\text { R-squared }\end{array}$ \\
\hline Computer Ownership & .0425385 & $\underline{0.36}$ & $\underline{0.716}$ & \multirow{6}{*}{$\underline{0.1981}$} & \multirow{6}{*}{0.1682} \\
\hline $\begin{array}{l}\text { Years of Computer } \\
\text { Experience }\end{array}$ & -.0183714 & -1.23 & 0.222 & & \\
\hline $\begin{array}{l}\text { Hours of Daily Computer } \\
\text { Use }\end{array}$ & .0635443 & $\underline{2.99}$ & $\underline{0.003}$ & & \\
\hline $\begin{array}{l}\text { Self-Evaluation of } \\
\text { Computer Experience }\end{array}$ & .1726566 & $\underline{2.49}$ & $\underline{0.014}$ & & \\
\hline Years of English Study & .013227 & 0.84 & 0.404 & & \\
\hline Cons & 2.974397 & 15.42 & 0.000 & & \\
\hline
\end{tabular}

* $\underline{p}<.05$

The analysis of data after conducting a factor analysis for computer knowledge components showed that computer knowledge of learners at IPA Dammam men's campus statistically had a role in the way they perceive CALL. The regression model showed that computer knowledge was statistically significant in learners' attitudes toward CALL $(p=.0 \odot \odot)$ and this regression model (see Table 4.25) explained 0.1303 of the variance in attitudes toward CALL. The null hypothesis of research question 4 that says there is no statistically significant difference among Saudi EFL learners' attitudes toward CALL at the IPA based on their computer knowledge is rejected for the Dammam men's campus. 
Table 4.25 Regression Model of Learners Attitudes toward CALL Based on Their Computer Knowledge at Dammam Men's Campus after Conducting Factor Analysis

\begin{tabular}{|l|c|c|c|c|c|}
\hline Attitudes toward CALL & Coef. & t & $\begin{array}{c}\text { P> I } \\
\text { t I }\end{array}$ & R-squared & $\begin{array}{c}\text { Adjusted } \\
\text { R-squared }\end{array}$ \\
\cline { 1 - 4 } $\begin{array}{l}\text { Computer Knowledge } \\
\text { (Factor Analysis) }\end{array}$ & $\underline{.1934173}$ & $\underline{4.54}$ & $\underline{0.000}$ & & \\
\cline { 1 - 4 } Years of English Study & .00785 & 0.49 & 0.622 & $\underline{0.1428}$ & $\underline{0.1303}$ \\
\cline { 1 - 3 } Cons & 3.679006 & 33.04 & 0.000 & & \\
\hline
\end{tabular}

* $\underline{p}<.05$

IPA Jeddah Men's Campus

The regression model of Jeddah men's campus showed that computer ownership statistically did not represent any significant difference in learners' attitudes toward CALL $(p=.0252) . \quad$ Learners' years of experience in computer did not also statistically have any significant difference in the attitudes they hold toward CALL at IPA Jeddah men's campus $(p=0.909)$. As with computer ownership and years of experience in computer, the hours of daily use of computer also had no statistically significance in learners attitudes toward CALL $(p=0.482)$. Only the self-evaluation of computer knowledge components had a statistically significant difference in IPA Jeddah learners' attitudes toward CALL $(p=0.013)$. Table 4.26 explains the regression model of computer knowledge components. 
Table 4.26 Regression Model of Learners' Attitudes toward CALL Based on Their Computer Knowledge at Jeddah Men's Campus

\begin{tabular}{|c|c|c|c|c|c|}
\hline Attitudes toward CALL & Coef. & $\mathbf{t}$ & $\begin{array}{cc}> & I \\
t & \mid\end{array}$ & R-squared & $\begin{array}{c}\text { Adjusted } \\
\text { R-squared }\end{array}$ \\
\hline Computer Ownership & .1121716 & $\underline{1.15}$ & $\underline{0.252}$ & \multirow{6}{*}{$\underline{0.0905}$} & \multirow{6}{*}{0.0506} \\
\hline $\begin{array}{l}\text { Years of Computer } \\
\text { Experience }\end{array}$ & -.0019778 & -0.12 & $\underline{0.909}$ & & \\
\hline $\begin{array}{l}\text { Hours of Daily Computer } \\
\text { Use }\end{array}$ & $\underline{-.0159893}$ & $\underline{-0.70}$ & $\underline{0.482}$ & & \\
\hline $\begin{array}{l}\overline{\text { Self-Evaluation of }} \\
\text { Computer Experience }\end{array}$ & .151935 & $\underline{2.53}$ & $\underline{0.013}$ & & \\
\hline Years of English Study & .0071803 & 0.43 & 0.665 & & \\
\hline Cons & 3.193344 & 17.46 & 0.000 & & \\
\hline
\end{tabular}

${ }^{*} \underline{p}<.05$

The factor analysis of computer knowledge showed that computer knowledge did statistically affect the learners' attitudes toward CALL at Jeddah men's campus $(p=0.024)$ ( Table 4.27). This regression model explained .0359 of attitudes toward CALL that Saudi EFL learners hold. Based on these findings, the researcher rejected that null hypothesis of research question 4 that says that there is no statistically significant difference among Saudi EFL learners' attitudes toward CALL at the IPA based on their computer knowledge for the Jeddah men's campus. 
Table 4.27 Regression Model of Learners' Attitudes toward CALL Based on Their Computer Knowledge at Jeddah Men's Campus after Conducting Factor Analysis

\begin{tabular}{|l|c|c|c|c|c|}
\hline Attitudes toward CALL & Coef. & t & $\begin{array}{c}\text { P> I } \\
\text { t I }\end{array}$ & R-squared & $\begin{array}{c}\text { Adjusted } \\
\text { R-squared }\end{array}$ \\
\cline { 1 - 4 } $\begin{array}{l}\text { Computer Knowledge } \\
\text { (Factor Analysis) }\end{array}$ & $\underline{.1153615}$ & $\underline{2.29}$ & $\underline{0.024}$ & & \\
\cline { 1 - 4 } Years of English Study & .0018409 & 0.11 & 0.911 & \multirow{2}{*}{0.0521} & $\underline{0.0359}$ \\
\cline { 1 - 3 } Cons & 3.741112 & 33.94 & 0.000 & & \\
\hline
\end{tabular}

* $\underline{p}<.05$

Research Question 5

What are the differences between Saudi EFL learners' attitudes toward CALL at the IPA based on their gender?

Null hypothesis 5: There is no statistically significant difference among Saudi EFL learners' attitudes toward CALL at the IPA based on their gender.

To answer this question, the researcher did a t-test to compare the two means of equal sample of learners' general attitudes at Riyadh men's campus and Riyadh women's campus. The Dammam and Jeddah campuses were excluded of this statistical method since there are no IPA women's campuses located in these two cities. Thus, for the accuracy of the findings, a t-test was to conduct the analysis between Riyadh men's campus and Riyadh women's campus. 
The t-test results showed that statistically significant gender differences were found. The results showed that Saudi women EFL learners hold more positive attitudes than their men counterparts $(t=5.4522)$. Table 4.28 explains the $t$-test results.

Table 4.28 t-test of Two Means of Learners' Attitudes toward CALL at Riyadh Women's and Men's Campus

\begin{tabular}{|l|c|c|c|c|}
\hline Variable & Mean & $\begin{array}{c}\text { Standard } \\
\text { Deviation }\end{array}$ & $\begin{array}{c}\text { Standard } \\
\text { Error }\end{array}$ & $t$ \\
\cline { 1 - 3 } $\begin{array}{l}\text { Female Learners' } \\
\text { Attitudes toward CALL } \\
\text { at Riyadh Women's } \\
\text { Campus }\end{array}$ & 3.979603 & .4159277 & .0370538 & \\
\hline $\begin{array}{l}\text { Male Learners' } \\
\text { At titudes toward CALL } \\
\text { at Riyadh Men's } \\
\text { Campus }\end{array}$ & 3.664921 & .4967249 & .0442518 & \\
\hline
\end{tabular}

These findings showed that gender had a role in the attitudes that IPA learners form toward CALL at the IPA and based on that, the null hypothesis of research question 5 that states that there is no statistically significant difference among Saudi EFL learners' attitudes toward CALL at the IPA based on their gender was rejected for the Riyadh men's campus and the Riyadh women's campus. 


\title{
CHAPTER FIVE: SUMMARY, FINDINGS \& DISCUSSION, CONCLUSION, AND RECOMMENDATIONS
}

\author{
Summary
}

Purpose of the Study

The study was concerned with understanding how Saudi EFL learners perceive the use of CALL in their language studying. The researcher was able to cast a light and obtain a clear picture of Saudi EFL learners' attitudes toward the use of technology. The purpose of the study, in particular, was to give a clear picture of Saudi EFL learners' attitudes toward CALL at the Institute of Public Administration. The study aimed to identify learners' general attitudes toward CALL, attitudes toward the CALL software at the IPA, the effect of learners' years of English study on the general attitudes toward CALL, the influence of computer knowledge on the attitudes the learners hold toward CALL, and gender differences in learners' attitudes toward CALL. Specifically, five research questions guided this study:

Research question 1: What are the Saudi EFL learners' attitudes toward CALL in general at the IPA?

Research question 2: What are Saudi EFL learners' attitudes toward the CALL software used at the IPA? 
Research question 3: What are the differences between Saudi EFL learners' attitudes toward CALL at the IPA based on their years of English learning?

Research question 4: What are the differences between Saudi EFL learners' attitudes toward CALL at the IPA based on current computer knowledge?

Research question 5: What are the differences between Saudi EFL learners' attitudes toward CALL at the IPA based on their gender?

Research Design and Procedure

Both descriptive and inferential statistics were used to answer the research questions. For the research question 1 and 2, descriptive statistics were used, namely, the mean and standard deviation. The inferential statistics were used to answer research questions 3,4 , and 5, and both regression and $t$-test were conducted. The dependent variable of the study was the Saudi EFL learners' attitudes toward CALL in general. There were three independent variables in the study, years of English study, computer knowledge, and gender. Years of English study refers to the number of years that a learner has spent studying English. Learners' computer knowledge was measured by combining four components: ownership of computers, years of computer experience, hours 
of daily computer use, and self-evaluation of computer experience. Gender refers to female or male.

The participation in the study was voluntary. The participants totaled 578 from the IPA Riyadh men's campus, IPA Riyadh women's campus, IPA Dammam men's campus, and IPA Jeddah men's campus. Female participants represent $21 \%$ and male participant represent $78 \%$ of the sample size of the study .

\section{Findings and Discussion}

1. The study found that Saudi EFL learners had positive attitudes toward the use of CALL $(M=3.75)$. The results also showed that IPA female learners at Riyadh women's campus had a significantly better attitudes toward CALL $(M=3.98)$ than males in Riyadh men's campus $(M=3.61)$, Dammam men's campus $(M=3.73)$ and Jeddah men's campus on the Red sea coast $(M=3.75)$. The findings showed that IPA learners in Jeddah men's campus came in the second place in their general attitudes toward CALL $(M=3.75)$ after the Riyadh women's campus and on the top of IPA males learners. Learners in IPA Dammam men's campus was the third in their general attitudes toward CALL $(M=3.73)$ and the second comparing other two 
men's campuses. The IPA Riyadh men's campus learners came in the last place in attitudes toward CALL $(M=3.61)$.

The results of this question coincide with results of other findings of Chen (2003), Ayres (2002), Stevens (1991), Almekhlafi (2006), Jabir \& Omar (2000), and Yushau (2006) that all showed the positive attitudes of learners toward the use of computers in instruction.

2. Beside their positivity toward CALL, the IPA Saudi EFL learners showed, although with a less degree, satisfactory attitudes toward the CALL software (The New Dynamic English) that is used in all IPA CALL labs $(M=3.23)$. The IPA Dammam men's campus on the Arabian Gulf coast expressed the highest positive attitudes toward the software among the other three IPA campuses $(M=3.53)$. Learners at the IPA Jeddah men's campus came in the second place ( $M=$ 3.51). Learners at Riyadh, both women and men campuses, respectively were the lowest in their satisfactory attitudes toward the New Dynamic English software. The mean of women learners' attitudes was 3.26 and for the men's learners was 3.23. It is worth-noticed that the answer of research question 2 also showed that the IPA location may have a role in learners' attitudes toward the CALL software since the IPA learners at campuses on the east and west coasts of Saudi Arabia expressed more positivity toward the software than 
their counterparts in the Riyadh the capital. The researcher did not find previous studies investigating the attitudes toward the New Dynamic English software to compare the findings of this study with.

3. The results of question 3 showed that the number of years that Saudi EFL learners at IPA have spent studying English statistically had no effect on their attitudes toward CALL (see Table 15, p. 84). The analysis of data for the four IPA campuses showed similar results. That is, the period of time the Saudi EFL learners have spent learning English had no role in the way they perceive CALL. The results of this question are consistent with Chen's (2003) findings. She found that the number of years of English learning of Taiwanese learners had no effect on their attitudes toward the use of technology in English learning. Therefore as stated in the null hypothesis 3, the years of English study have no effect on Saudi EFL learners' attitudes toward CALL at the IPA was true and years of English study cannot be used as a predictor variable of Saudi EFL learners' attitudes toward CALL at the IPA.

4. The answer to research question 4 showed that there existed a significant difference on learners' attitudes toward CALL based on their the computer knowledge. Computer knowledge of IPA learners in this study was defined by 
combination of four dimensions: computer ownership, years of computer experience, hours of daily use, and self-evaluation of computer experience. The analysis of data from the four IPA campuses revealed that computer knowledge was a key factor in the formation of the IPA Saudi EFL learners' attitudes toward CALL. Particularly, hours of daily computer use and self-evaluation of computer experience were the highly significant components of the computer knowledge variable. This means that the more daily exposure to computers the Saudi EFL learners have and the higher they consider their computer level, the more the positive attitudes toward CALL they hold. Hence, the null hypothesis stating that computer knowledge has no effect on students' attitudes toward CALL at the IPA was rejected and computer knowledge of learners cab be used as a strong predictor of Saudi EFL learners' attitudes toward CALL at the IPA.

These findings coincide with findings by Chen (2003), Liu (1997), Loyd \& Gressared (1984), Ruffin (2000), Macllroy et al. (2001), Chua et al. (1999), and Igbaria \& Chakrabarti (1990) .

5. The answer to question 5 showed that gender variable played a strong role in the attitudes of the IPA Saudi EFL learners toward CALL. Two mean comparison was made between the IPA female and male students in Riyadh only since there 
are no other women campuses in Dammam and Jeddah. The Women learners at the IPA expressed more positivity toward CALL than the IPA men learners in Riyadh $(t=5.4522)$. The results showed that women students were more open toward the use of computers in the IPA English program. Based of that, gender can serve as a strong predictor of learners' attitudes toward CALL at the IPA and the null hypothesis of research question 5 stating that there is no statistically significant difference among Saudi EFL learners' attitudes toward CALL at the IPA based on their gender was rejected.

These findings are not compatible with findings from other studies that favored male learners' attitudes toward the use of computers in instruction than female students (Chua et al. 1999; Shashanni, 1997; Chin, 2001; Brosnan, 1998 in the UK students; Durndell \& Haag, 2002) and with results from research that found gender has not effect on learners' attitudes toward the use of computers in instruction. Examples include Taghavi (2001), Brosnan (1998) in the Hong Kong learners, Jennings \& Onwuegbuzie (2001), and Abdelhamid (2002) .

Conclusion

The attitudes of learners are the foundation for the success of any learning process. Attitudes of students in 
language learning are no exception, but rather crucial and considered to be one of the most determining elements in the language learning success (Smith, 1971; Ganschow et al., 1994; Gardner \& Lambert, 1972, 1995; Krashen, 1987; Savignon, 1976). The more positive attitudes the learners have toward a language being taught, the more the chances of that language acquisition. Same with language learning, learners' attitudes toward technology represented by computers have a great effect on the success of using it in instruction (AlKhaldi \& Al-Jabri, 1998; Selwyn, 1999 in Palaigeorgiou, et al., 2002).

The whole idea of CALL, as mentioned in chapter 1 , is to put the computer capabilities in the hands of language learners to help them heading forward in their learning. Advantages of CALL were well-presented and documented by many researchers. The main point is that CALL is not a panacea and its implementing should go beyond buying computers, software, equipments, and having the students learned. It is a matter that is formed by many components and the cornerstone is the students' attitudes. Learners are the only determiner of the success or failure of CALL. Therefore, the issue on CALL should not be that the learners use it, but rather the learners like and benefit from it. Hence, the goal of this study came. The study primarily was 
to obtain a profile of the attitudes that Saudi EFL learners have toward CALL in general, and more specifically at the IPA in Saudi Arabia.

Based on the finding of the study, the IPA learners accept the technology in teaching English and look at computers as a useful and helpful tool in their English learning. Their positive attitudes can be interpreted in different ways. One of the main interpretations is the IPA learners do have the notion that CALL offers them some help in improving their English beside their traditional classrooms. This notion helps the IPA instructors and administration to get the utmost advantages from CALL by promoting these attitudes.

English learners at the IPA also expressed, even with a less degree than CALL in general, positive attitudes toward the software. This indicates that they have also an opinion that the New Dynamic English software offers them some help in their study.

Years of English study has nothing to do with the Saudi EFL learners' attitudes toward CALL. This shows that number of year of English learning the Saudi EFL learners have spent, has no effect on the way they perceive the use of computers in English learning. The IPA learners' attitudes toward CALL are mainly influenced by two factors, the 
knowledge they have in computers and their gender. The more the computer knowledge the learners have, the more the positive attitude they hold toward CALL. In addition, the Saudi women EFL learners tend to have more positive attitudes toward CALL than do the men learners. Learners' knowledge of computer and gender prove to be the main predictors of the attitudes toward CALL that the Saudi EFL learners hold at the IPA.

Recommendations

In order for CALL instruction to be successful in the English program at the IPA, several recommendations need to be taken into consideration. The recommendations are given into the following subsections.

Recommendation for Instructors

The IPA English instructors have a great role to play in promoting their learners' attitudes toward CALL. The IPA EFL instructors can foster their learners' attitudes by:

1. Explaining to their learners what CALL is and what it can offer. CALL is relatively new technology that only few learning institutions use in Saudi Arabia, most of the IPA learners have never seen CALL consequently, they have no idea about what CALL can provide. 
2. Surveying their learners' knowledge in computers. Those with poor or no knowledge should be given more attention.

3. Helping and guiding the learners when they work in CALL labs to make them feel secure and less anxious when working with computers especially students with no or little computer knowledge.

4. Familiarizing their students with the CALL software (Milheim, 1993).

5. Providing the students with sufficient technical support they may need.

6. Encouraging students to use computer at home to learn English .

7. Surveying the problems the learners have with CALL and work with the IPA administration to solve them. 8. Providing their students useful links for the English learning websites. Today, there are hundreds of good websites that offer learners different variety in English learning. These websites provide learners with lessons, exercises, materials, interactions with other learners around the world, and programs. By doing so, learners will improve their English and they will have more exposure to computer leading to more positive attitudes toward CALL. 
Recommendations for Curriculum

Curriculum designers at the IPA intensive English program can help in making CALL more efficient in the program taking the following suggestions into consideration:

1. CALL labs materials should be directly related to what learners study at their traditional classrooms. Integrating CALL with the traditional classroom activities will make students concentrate more and stop Learners' focus from being dispersive between the two .

2. Human dimension should be given to the CALL labs by activating the CMC feature. IPA CALL labs should be connected to the internet and arrangements should be made with other language institutions inside and outside Saudi Arabia to allow the IPA learners communicating with native speakers and with their counterparts in Saudi Arabia and other countries. This human dimension will foster IPA learner language skills, particularly their communication skills by practicing what they learn. It will also show the students that they do not work only with machines when they go to the CALL labs. 
3. CALL lab hours should be increased in the curriculum so that students by time feel familiar with the CALL environment.

4. Hours of CALL labs should be divided equally between the four language skills. All language skills should be benefit from CALL.

5. Computer literacy courses should be included in the curriculum, especially for those with no computer skills.

Recommendations for the IPA Administration

To get the utmost benefit from CALL, decision makers at the IPA should take some steps to enhance the Saudi EFL learners' attitudes toward CALL. This can be done by the following:

1. Making CALL labs available in different times for students so they can go and practice.

2. Installing other kinds of software and not only the New Dynamic English. This will give students the choice to choose what fit them among a variety of software programs.

3. Installing only software programs that are appropriate for both Saudi learners and instructors and fit their Islamic and Arab culture (Alkahtani, 2004). 
4. Providing the IPA learners with copies of the CALL software that students can practice them.

5. Offering computers to Saudi EFL learners at the IPA either free or with lower prices.

6. Installing computer labs at the IPA dormitories to get learners exposed more to computers.

7. Providing learners at IPA dormitories with internet access .

8. The current number of computers at each campus library is completely not sufficient. For example, in Riyadh men's campus library, there are only 25 computers, and only four computers are linked to the internet. At the IPA women's branch library, only four computers are available for the learners. In Dammam men's campus, there are only 7 computers, and only four of them are liked to the internet. Finally, at Jeddah men's campus, there are only 5 computers and only one computer is connected to the internet. These numbers show that IPA Saudi EFL learners have less if no opportunity to use computers at the IPA. Therefore, there is a strong need for increasing the number of computers at the IPA libraries in the four campuses. 
9. There is also a need to install computer labs in different IPA campuses to make the use of computers available for learners.

10. The IPA instructors should be given the proper training that enables them to fully understand the whole CALL procedures.

11. Only IPA English teacher with positive attitudes toward CALL should be assigned to work with students in the CALL labs.

12. Hiring only English instructors with good computer knowledge. Teachers with good computer experience will be easily able to deal with CALL setting and help the students overcome the problems they face working with CALL.

Recommendation for Future Research

There is a need for replications of this study with more participants from different English institution in Saudi Arabia. Replication of the study will support the validity of these research findings. In addition, a guide line will be set to assess Saudi language learners' attitudes toward the use of computers in instruction.

Significant variables of this study should be used in future research. Future quantitative research should 
increase the number of items on computer knowledge, particularly, computer use and self-evaluation dimensions in their surveys.

There are other factors that contribute to the Saudi EFL learners attitudes toward CALL. Qualitative research methods, particularly interviews are recommended to probe these factors. Interviews with learners will provide more interesting details on the way that students perceive the use of computers in their English studies.

There are a gender gap exists in Saudi EFL learners' attitudes toward CALL at the IPA. Future studies should explore the reasons behind this gap and give suggestions to eliminate it. Both statistical analysis and qualitative methods should be used to cast the light on this difference. 


\section{REFERENCES}

Abalhassan, K. M. (2002). English as a foreign language instruction with CALL multimedia at Saudi Arabian private school: A multi-case and multi-site study of call instructors' pedagogies and beliefs. (Doctoral dissertation, Indiana University of Pennsylvania, 2002). Dissertations Abstracts International, 65/11, 4086.

Abdelhamid, I. S. (2002). Attitudes toward computers: a study of gender differences and other variables. Journal of the Social Science, 30 (2), 285-316.

Ahmed, K., Corbett, G., \& Rogers, M. (1985). Computer, language learning and language teaching. Cambridge: Cambridge University Press.

Ajzen, I., \& Fishbein, M. (1977). Attitude-behavior relations: a theoretical analysis and review of empirical research. Psychological Bulletin, 84, 888-918.

Al-Juhani, S. 0. (1991). The effectiveness of computerassisted instruction in teaching English as a foreign language in Saudi secondary school. (Doctoral dissertation, University of Denver, 1991). Dissertations Abstract International, 52/07, 2383.

Al-Kahtani, S. A. (2001). Computer-assisted language learning in EFL instruction at selected Saudi Arabian universities: Profiles of faculty. (Doctoral dissertation, University of Indiana at Pennsylvania, 2001). Dissertations Abstract International, 62/9, 2994.

Al-Khaldi, M., \& Al-Jabri, I. (1998). The relationship of attitudes to computer utilization: new evidence from a developing nation. Computers in Human Behaviors, 17(4), $23-42$.

Alkahtani, S. (2004). Deterrents to CALL in Saudi Arabia. Essential Teacher, 1 (3), 26-30. 
Almekhlafi, A. G. (2006). The effect of computer assisted language learning (CALL) on United Arab Emirates English as a foreign language (EFL) school student's achievement and attitudes. Journal of Interactive Learning Research, 17 (2), 121-142.

Alrumaih, A. A. (2004). Multimedia instructional applications for pronunciation instructions in English as a foreign language setting in Saudi Arabia: A study of attitudes, beliefs, and pedagogies (Doctoral dissertation, Kansas State University, 2004). Dissertation Abstracts International, 65/11, 4083.

Anderson, A. A. (1996). Predictor of computer anxiety and performance in information systems. Computers in Human Behavior, 12 (1), 61-77.

Anderson, D. M. (2001). Assessing attitudes toward computers and the use of internet resources among undergraduate microbiology students (Doctoral dissertation, The University of Southern Mississippi, 2001). Dissertations Abstracts International, 62/05A, 1805.

Anselm, S. (1945). The concept of attitude in social psychology. Journal of Psychology 19, 329-339.

Atkinson, R. (1965). Computer-assisted learning in action. Proceedings of the National Academy of Science of the United States of America, 63 (3), 588-594.

Ayres, R. (2002). Learner attitudes toward the use of CALL. Computer Assisted Language Learning, 15 (3), 241-249.

Azriel, J., Erthal, M., \& Star, E. (2005). Anwers, questions, and deceptions: what is the role of games in business educations. Journal of Education for Business, 8 (1), 913.

Bacon, S., \& Finnemann, M. (1990). A study of attitudes, motives, and strategies of university foreign language students and their disposition to authentic oral and written input. The Modern Language Journal, 74 (4), 459473 .

Bax, S. (2003). CALL-past, present and future. System, 31, $13-28$. 
Beatty. K. (2003). Teaching and researching computer-assisted language learning. London: Pearson Education.

Bozionelos, N. (2001). Computer anxiety: relationship with computer experience and prevalence. Computers in Human Behavior, 17(2), 213-224.

Bromley, C. (1995). Positive attitude and realistic beliefs: links to proficiency. Modern Language Journal, 79 (3), 372-386.

Brosnan, M. (1998). A cross-cultural comparison of gender differences in computer attitudes and anxieties: the United Kingdom and Hong Kong. Computer in Human Behavior, 14 (4), 559-577.

Chapelle, C. (2001). Computer applications in second language acquisition. UK: Cambridge.

Chapelle, C. (2003). English language learning and technology. PA: John Benjamins.

Chen, P. (2003). EFL student learning style preferences and attitudes toward technology-integrated instruction. (Doctoral dissertation, University of South Dakota, 2003). Dissertations Abstracts International, 64/8, 2813 .

Cheng, W., Warren, M., \& Xun-feng, X. (2003). The language learner as language researcher: putting corpus linguistics on the timetable. System, 31, 173-186.

Chua, S. L., Chen, D., \& Wong, A. F. L. (1999). Computer anxiety and its correlates: a meta-analysis. Computers in Human Behavior, 15, (5), 609-623.

Coughlin, J. (1990). Artificial intelligence and computerassisted language learning: present developments and future prospects. The French Review, 63, 560-565.

Collie, J., \& Slater, S. (1987). Literature in the language classroom. Cambridge: Cambridge University Press. 
Dunkel, P. (1987). Computer-assisted instruction (CAI) and computer-assisted language learning (CALL): past dilemmas and future prospects for audible CALL. The Modern Language Journal, 71, 250-260.

Dunkel, P. (1990). Implications of the CAI effectiveness research for limited English proficient learners. Computer in the Schools, 7 (1-2), 31-52.

Durndell, A., \& Haag, Z. (2002). Computer self-efficacy, computer anxiety, attitudes towards the internet and reported experience with the internet, by gender, in an East European sample. Computers in Human Behavior, 15 (5), 521-535.

Egbert. J. (2005). CALL essentials principles and practice in CALL classrooms. Virginia: TESOL.

Egbert, J. L., Jessup, L.M., \& Valacich, J. S.(1991). Interactive CALL for groups: new technologies for ESL. CAELL Journal, 2. 18-24.

Ellis, R. (1997). Second Language Acquisition. 0xford: Oxford University Press.

Ertmer, P. A., Evenbeck, E., Cennamo, K. S., \& Lehman, J.D. (1994). Enhancing self-efficacy for computer technologies through the use of positive classroom experience. Educational Technology, Research and Development, 42, 45-62.

Esling, J. (1991). Research the effect of networking. In P. Dunkel (Ed.), Computer-assisted language learning and testing research issue and practice (pp.111-132). New York: Newbury House.

Field, A. (2000). Discovering statistics. London: SAGE Publications.

Fitzgerald, Sue., Bower, H., \& Morrall, A. (1999). CALICO Software Review. Retrieved July 13, 2006, from CALIC0 Web site http://calico.org/CALICO_Review/review/dynengoo.htm. 
Fotos, S., \& Browne, C. (2004). The development of CALL and current options. In S. Fotos \& C. Brown (Eds.), New perspectives on CALL for second and foreign language Classrooms (pp. 3-14). Mahwah, NJ: Lawrence Erlbaum Associates.

Ganshcow, L., Sparks, R., Anderson, R., Javorshy, J., Skinner, S., \& Patton, J. (1994). Differences in language performance among high-, average-, and low anxious college foreign language learners. The Modern Language Journal, 78, 41-55.

Gardner, R. C., \& Lambert, W. E. (1972). Attitudes and motivation in second-language learning. Massachusetts: Newbury House Publisher.

Gardner, R. C. (1996). Motivation and second language perspectives. Journal of the CAAL, 18, 19-42.

Gay, L.R., Mills, G., Airsain, P. (2006). Educational research, competencies for analysis and applications (8th ed.). New Jersey: Pearson.

Gravetter, F., \& Wallnau, L.B. (2007). Statistics for the behavior science $\left(8^{\text {th }}\right.$ ed.). California: Thomson wadsworth.

Greenwald, A.G., Brock, T.C., \& Ostrom, T.M. (1968). Psychological foundations of attitudes. New York: Academic Press.

Hair, J. F., Black, B., Babin, B., Anderson, R. E., \& Tatham, R. L. (2005). Multivariate data analysis $\left(6^{\text {th }}\right.$ ed.). London: Prentice Hall.

Hanson-Smith, E. (1999). Classroom practice: content-area tasks in CALL environments. In J. Egbert \& E. Hanson-

Smith (Eds.), CALL environment: research, practice, and critical issues (pp. 137-158). Virginia: TESOL.

Hertz, R. (1987). Computer in the language learning. California: Addison-Wesley. 
Hiple, D. \& Fleming, S. (2002). Foreign language distance learning: the university of Hawaii experience. In C. Spreen (Ed.), New technologies and language learning: cases in the less commonly taught language (pp. 1-12). Hawaii: University of Hawaii Press.

Howard, G.S., Murphy, C.M., \& Thomas, G.N. (1987). Computer anxiety considerations for design of introductory computer courses. Educational Research Quarterly, 11(4), 13-22.

Iandoli, L. J. (1990). CALL and the profession: the current state. The French Review, 64 (2), 261-272.

Igbaria, M., \& Chakrabarti, A. (1990). Computer anxiety and attitudes towards microcomputer use. Behavior \& Information Technology, 9, (3), 229-241.

Jabir, M., \& Omar, A. (2002). Students' and teachers' attitudes toward computer in the schools in southern governorates of Jordan. Dirasat: Educational Sciences, 27 (2), 312-327.

Jennings, S. E., \& Onwuegbuzie, A. J. (2001). Computer attitudes as a function of age, gender, math attitude, and developmental status. Journal of Educational Computing Research, 25 (4), 367-384.

Jung, S. (2006). Computer ownership \& attitudes. Retrieved June 2, 2006, from http://edtechoutreach. umd. edu/Presentations/Micca2005/MI CCASei-HwaJung . ppt\#276, 10, IV .

Kern, R., \& Warschauer, M. (2000). Introduction: theory and practice of network-based language teaching. In $M$. Warschauer \& R. Kern (Eds), Network-based language teaching: concepts and practice (pp. 1-19). Cambridge: Cambridge University Press.

Kern, R. (1995). Restructuring classroom interaction with network computers: effects on quantity and characteristics of language production. Modern Language Journal, 79 (4), 457-476.

Krashen, S. (1985), The Input hypothesis: issues and implications, London: Pearson Longman. 
Krashen, S.D. (1987). Principles and practice in second language acquisition. London: Prentice Hall.

Krieger, D. (2003 March). Corpus linguistics: what it is and how it can be applied to teaching. The Internet TESL Journal, 6, 2. Retrieved June 16, 2006.

Lee, J. F., \& VanPatten, B. (2003). Making communicative language teaching happens $\left(2^{\text {nd }}\right.$ ed.). New York: McGraw Hill.

Levy, M. (1997). Computer-assisted language learning context and conceptualization. New York: 0xford University Press.

Levy, M. (2005). Why call CALL "CALL"?. Computer Assisted Language Learning, 18 (3), 143-149.

Lin, N. T. (2002). Motivation and attitude toward integrated instruction through technology in college-level EFL reading and writing in Taiwan. (Doctoral dissertation, University of Pittsburgh, 2002). Dissertation Abstract International, 64/01, 59.

Lin, R. L. \& Miller M. D. (2005). Measurement and assessment in teaching (9th ed.). New Jersey: Pearson.

Liu, Gonghua. (1997). The attitudes of Chinese students at the University of Tennessee toward the computer (Doctoral dissertation, North Dakota State University, 1997). Dissertations Abstracts International, 58/6-A, 2104 .

Loyd, B.H., \& Gressard, C. (1984a). Reliability and factorial validity of computer attitude scales. Educational and Psychological Measurement, 44 (2), 501-505.

Loyd, B. H., \& Gressard, C. (1984b). The effect of sex, age, and computer experience on computer attitudes. AEDS Journal, $18(2), 67-77$.

Loyd, B. H., \& Loyd, D. E. (1985). The reliability and validity of an instrument for the assessment of computer attitudes. Educational and Psychological Measurement, $45,903-908$. 
Masgoret, A.M., \& Gardner, R.C. (2003). Attitudes, motivation, and second language learning: a metaanalysis of studies conducted by Gardner and associates. In Z. Dörnyei (Ed.), Attitudes, Orientations, and Motivations in Language Learning. ( $p$. 167-210). Massachusetts: Blackwell Publishing.

Mcllroy, D., Bunting, B., Tierney, K., \& Gordon, M. (2001). The relation of gender and background experience to self-reported computing anxieties and cognitions. Computers in Human Behavior, 17 (1), 21-33.

Milheim, W. (1993). Using computer-based instruction with adult learners. The Journal of Continuing Higher Education, 12 (1), 2-8.

Min, B. (1998). A study of the attitudes of Korean adults toward technology-assisted instruction in Englishlanguage programs (Doctoral dissertation, Northern Illinois University, 1998). Dissertation Abstracts International, 59/05-A, 1430 .

Mitra, A., Steffensmeier, T., Lenzmeier, S., \& Massoni, A. (1999). Changes in attitudes toward computers and use of computers by university faculty. Journal of Research on Computing in Education, 32 (1), 189-202.

Mitra, A., \& Hullett, C. (1997). Toward evaluating computer aided instruction: attitudes, demographics, context. Evaluation and Program Planning, 2 (4), 379-391.

Mosquera, F. (2001). CALT: exploiting internet resources and multimedia for TEFL in developing countries. Computer Assisted Language Learning, 14 (5), 461-468.

Oxford, R. L. (2001). Language learning strategies. In R. Carter, \& D. Nunan (Eds.), Teaching English to speakers of other languages (pp. 166-172). Cambridge: Cambridge University Press.

Palaigeorgiou, G. E., Siozos, P.D., Konstantakis, N.I., \& Tsoukalas, I.A. (2005). A computer attitude scale for computer science freshmen and its educational implications. Journal of Computer Assisted Learning, 21, $330-342$. 
Pennington, M. (2004). Electric media in second language writing: an overview of tools and research findings. In S. Fotos \& C. Brown (Eds.), New perspectives on CALL for second and foreign language Classrooms (pp. 69-92). Mahwah, NJ: Lawrence Erlbaum Associates.

Peterson, M. (1997). Language teaching and networking. System, 28 (1), 29-37.

Pope-Davis, D. B., \& Vispoel, W. P. (1993). How instruction influences attitudes of college men and women towards computer. Computers in Human Behavior, 91 (1), 83-93.

Purushotma, R. (2005). Commentary: you're not studying, you are just.... Language Learning \& Technology, 9 (1), 80-96.

Read, B. (1928). An attitude on attitude research. American Journal of Sociology, 33, 940-957.

Reed, F. (1992). Toward a reconceptionalization of attitudebehavior consistency. Social Psychology Quarterly, 55 (2), 205216.

Reinen, I. J., \& Plomp, T. (1993). Some gender issues in educational computer use: results of an international comparative survey. Computers and Education, 20 (4), 353-365.

Richards, J., \& Rodgers, T. (2001). Approaches and methods in language teaching $\left(2^{\text {nd }}\right.$ ed.). Cambridge: Cambridge University Press.

Rokeach, M. (1967). Attitude change and behavior change. The Public Opinion Quarterly, 30 (4), 529-550.

Ruffin, E. L. (2000). Computer-assisted instruction: demographic variables and student attitudes (Doctoral dissertation, The University of Oklahoma, 2000). Dissertation Abstracts International, 61/02A, 582.

Savigon, S. (1976). On the other side of the desk: a look at teacher attitude and motivation in second language learning. Canadian Modern Language Review, 7, 293-302. 
Schottenbauer, M. A., Rodriguez, B. F., Glass, C. R., \& Arnkoff, D. B. (2004). Computers, anxiety, and gender: an analysis of reactions to the Y2K computer problem. Computers in Human Behavior, 20, 67-83.

Selwyn, N. (1999). Students' attitudes toward computers in sixteen to nineteen education. Education and Information Technologies, 4, 129-141.

Shashaani, L. (1997). Gender differences in computer attitudes and use among college students. Journal of Educational Computing Research, 16 (1), 37-51.

Smith, B., Caputi, P., \& Rawstorne, P. (2000).

Differentiating computer experience and attitudes toward computers: an empirical investigation. Computer in Human Behavior, 16, 59-81.

Smith, A. (1971). The importance of attitudes in foreign language learning. The Modern Language Journal, 55 (2), 82-88.

Smith, B., Alrarex-Torres, M., \& Zhao, Y. (2003). Features of CMC technologies and their impact on language learners' online interaction. Computer in Human Behavior, 19, 703729.

Snowman, J. \& Biehler, R. (2006). Psychology applied to teaching $\left(11^{\text {th }}\right.$ ed.). Boston: Houghton Mifflin.

Sokolik. M. (2001). Computers in language teaching. In M.C. Murcia ( $\left.3^{\text {rd }} \mathrm{Ed}\right)$, Teaching English as a second or foreign language ( $\mathrm{pp} .477-488$ ). Boston: Heinle\&Heinle.

Stevens, V. (1991). A study of student attitudes toward CALL in a self-access student resource centre. System, 19 (3), 289-299.

St.John, E. (2001). A case for using a parallel corpus and concordancer for beginners of a foreign language. Language Learning and Technology, 5 (3), 185-203.

Merisuo-Storm, T. (2006). Pupils' attitudes toward foreignlanguage learning and the development of literacy skills in bilingual education. Teaching and Teacher Education, $23(2), 226-235$. 
Szendeffy, J. (2005). A practical guide to using computers in language teaching. Michigan: University of Michigan.

Taghavi, S. E. (2001). Evaluations of college students' attitudes toward computers before and after taking literacy course (Doctoral dissertation, Mississippi State University, 2001). Dissertations Abstracts International, 61/2-A, 541 .

Taylor, R. (1980). The computer in the school: tutor, tool, tutee. New York: Teacher College Press.

Taylor, R., \& Gitsaki, C. (2003). Teaching WELL in computerless classroom. Computer Assisted Language Learning, 16 (4), 275-294.

Taylor, R. \& Perez, L. (1989). Something to do on Monday. CA: Athelstan.

Thurstone, L. L. Comment. American Journal of Sociology, 50, $39-40$.

Underwood, J. (1984). Linguistics, computers and the language teacher: a communicative approach. Rowley, MA: Newbury House.

Cook, V. (2006). Krashen's comprehension hypothesis model of L2 learning. Retrieved May 2, 2006, from http://homepage.ntlworld.com/vivian.c/SLA/Krashen.htm.

Walker, B. (1994). EFL teachers' attitudes about CALL. CAELL Journal, $5(3), 12-15$.

Warschauer, M. (1996). Computer-assisted language learning: An introduction. In S. Fotos (Ed.), Multimedia language teaching (pp. 3-20). Tokyo: Logos International.

Warschauer, M., Turbee, L., \& Roberts, B. (1996). Computer learning networks and student empowerment. System, 24, 1-14.

Warschauer, M., \& Healey, D. (1998). Computers and language learning: an overview. Language Teaching, 31, 57-71. 
Warschauer, M. (2004). Technological change and the future of CALL. In S. Fotos \& C. Brown (Eds.), New Perspectives on CALL for Second and Foreign Language Classrooms (pp. 1525). Mahwah, NJ: Lawrence Erlbaum Associates.

Wenden, A.L. (1991). Learner strategies for learner autonomy. London: Prentice Hall.

White, W. (2007). Self-alienation, the language of discontent. Curriculum and Teaching Dialogue, 1\&2, 149155 .

Woodrow, J.E.J. (1991). A comparison of four computer attitude scales. Journal of Educational Computing Research, 7, 165-187.

Wretch, J. (1985). Vygotsky and the social formation of the mind. Cambridge, MA: Harvard University Press.

Wright, D. L. (1998). Radiography student learning style preferences and computer readiness (Doctoral dissertation, North Carolina State University, 1998). Dissertation Abstracts International, 59/03, 1033.

Yang, S. \& Chen, Y. (2007). Technology-enhanced language learning: a case study. Computers in Human Behavior, 23(1), 860-879.

Yoon, H., \& Hirvela, A. (2004). ESL student attitudes toward corpus use in L2 writing. Journal of Second Language Writing, 13, 257-283.

Yushau, B. (2006). The effect of blended e-learning on mathematics and computer attitudes in pre-calculus algebra. The Montana Mathematics Enthusiast, 3 (2), 176183.

Zimbardo, P.G. \& Leippe, M.R. (1991). The psychology of attitude change and social influence. New York: McGrawHill. 


\section{Appendix A: Survey Form (English Version)}

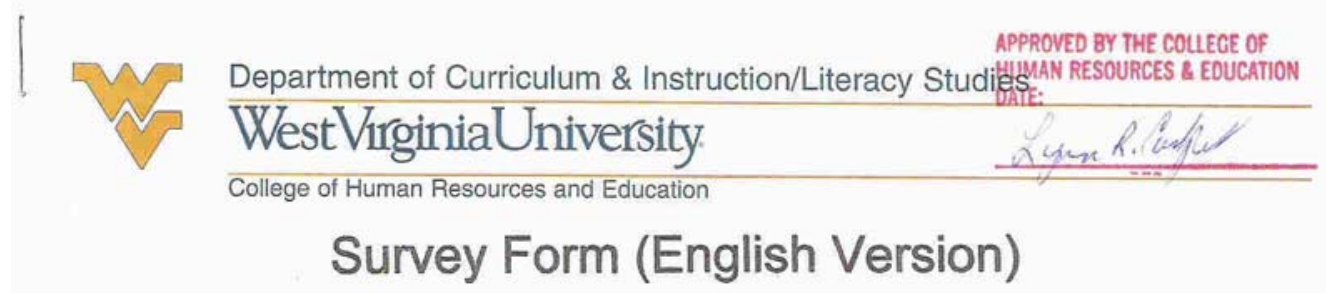

Dear Participant:

This survey is in partial fulfillment of the doctoral degree in the major of curriculum and instruction in the field of Teaching English to Speakers of Other Languages (TESOL). The study seeks to investigate English as a Foreign Language (EFL) learner' attitudes toward Computer-Assisted Language Learning (CALL) at the Institute of Public Administration (IPA) in Saudi Arabia. The study will contribute in developing and improving the use of computers in teaching English and other languages.

We are seeking your help by filling out this form honestly. The survey consists of two parts. The first is about demographic information whereas the second is a scale for measuring attitudes toward CALL. Please answer the questions in the first part by checking the proper response whereas in the second part choose the proper number (see part 2 for details).

Finally, I would like to assure you that completing this survey is voluntary. In addition, you have the right not to fill out this survey or any item you do not like to. If you wish to participate in this study, this survey is anonymous and does not require mentioning your name. It has no effect on your study or your grades. In addition, the data you provide will be confidential and will not be exposed except to the researcher and the research committee members.

Should you have any question, please email me at: malsham1@mix.wvu.edu

Sincerely,

Mishal H. Al Shammari

Ed D candidate

Department of Curriculum Theory \& Practice

College of Human Resources \& Education

West Virginia University 
Part One: Demographic Information

Code:

Direction: Please check $\square$ the appropriate response for each item.

1. IPA Location
$\square$ 1. Riyadh
$\square$ 2. Woman Branch
3. Dammam
$\square$ 4.Jeddah

2. Gender:

$\square$ 1. Male

2. Female

3. Age

$\square 1.18$

$\square 2.19$

3. 20

$\square 4.21$

$\square 5.22$

6. Other__ years

4. English learning background (years of English Learning)

$\square$ 1. Less than 6 years, please specify years

$\square$ 2. 6 years $\quad$ (Since Middle School)

$\square$ 3. 8 years $\quad$ (Since Senior Elementary School)

$\square 4.12$ years $\quad$ (Since Elementary School)

$\square$. Other number of years, please specify,

5. Current IPA English language level:
$\square$ 1. Preparatory
$\square$ 2. Elementary

$\square$ 3. Intermediate

$\square$ 4. Advanced

6. IPA major after graduating form IPA English Program:
$\square$ 1. Computer Programming
$\square$ 2. Computer Networking \& Operating Systems
$\square$ 3. Executive Secretary
$\square$ 4. Hospital Administration
$\square$ 5. Accounting
$\square$ 6. Sales
7. Banking
8. Information Studies and Libraries
$\square$ 9. Other, please specify,

7. Do you have a personal computer at home?
$\square$ 1. Yes
$\square$ 2. No

8. How long have you used a computer?

$\square$ Less than one year, please specify: months

$\square 1$ year

$\square 2$ years

$\square 3$ years

More than 3 years, please specify: years 
9. Outside of IPA classes, how much time do you spend using computers each day?

$\square$ Less than one hour, please specify: __ minutes.

$\square 1$ hour

$\square 2$ hours

$\square 3$ hours

$\square$ More than 3 hours, please specify: __ hours

10. I consider my knowledge of computer to be:

$\square$ Very Low

$\square$ Low

$\square$ Average

$\square$ Advanced

$\square$ Very Advanced 


\section{Section II: Scale of Attitude toward CALL (SACALL)}

Direction: The following are 30 general statements that describe your attitudes toward technology-integrated EFL instruction. Please think about each statement and circle the number that indicates how strongly you disagree or agree with each of the statement using a rating scale of 1 to 5 .

Circle "1" if you strongly disagree (SD).

Circle "2" if you disagree (D).

Circle " 3 " if you are uncertain (U).

Circle "4" if you agree (A).

Circle " 5 " if you strongly agree (SA).

\begin{tabular}{|l|l|l|l|l|l|l|}
\hline NO & \multicolumn{1}{|c|}{ Items } & SD & D & U & A & SA \\
\hline 1. & $\begin{array}{l}\text { Using computers to learn English does not scare me } \\
\text { at all. }\end{array}$ & 1 & 2 & 3 & 4 & 5 \\
\hline 2. & $\begin{array}{l}\text { I use computers in many ways to learn English (the } \\
\text { internet, software programs, etc). }\end{array}$ & 1 & 2 & 3 & 4 & 5 \\
\hline 3. & $\begin{array}{l}\text { It is easy to write my English assignments on the } \\
\text { computer. }\end{array}$ & 1 & 2 & 3 & 4 & 5 \\
\hline 4. & Learning English through computers is necessary. & 1 & 2 & 3 & 4 & 5 \\
\hline 5. & The CALL lab has sufficient technical support. & 1 & 2 & 3 & 4 & 5 \\
\hline 6. & $\begin{array}{l}\text { I prefer the activities in the CALL lab to the activities } \\
\text { in the regular classroom. }\end{array}$ & 1 & 2 & 3 & 4 & 5 \\
\hline 7. & $\begin{array}{l}\text { What I do in the CALL lab is related to classroom } \\
\text { activities. }\end{array}$ & 1 & 2 & 3 & 4 & 5 \\
\hline 8. & $\begin{array}{l}\text { I need a firm mastery of computers for my English } \\
\text { learning. }\end{array}$ & 1 & 2 & 3 & 4 & 5 \\
\hline 9. & Computers make English learning much easier. & 1 & 2 & 3 & 4 & 5 \\
\hline 10. & I want more use of computers in my EFL classes. & 1 & 2 & 3 & 4 & 5 \\
\hline 11. & Learning English in the CALL lab doesn't bother me. & 1 & 2 & 3 & 4 & 5 \\
\hline 12. & I often use computers to do my English assignments. & 1 & 2 & 3 & 4 & 5 \\
\hline 13. & I feel at ease learning English in the CALL lab. & 1 & 2 & 3 & 4 & 5 \\
\hline 14 & $\begin{array}{l}\text { The program used in the CALL lab helps me in } \\
\text { learning English. }\end{array}$ & 1 & 2 & 3 & 4 & 5 \\
\hline 15. & Writing on a computer does not make me nervous. & 1 & 2 & 3 & 4 & 5 \\
\hline
\end{tabular}




\begin{tabular}{|l|l|l|l|l|l|l|}
\hline NO & \multicolumn{1}{|c|}{ Items } & SD & D & U & A & SA \\
\hline 16. & $\begin{array}{l}\text { It is essential for EFL learners to master computer } \\
\text { skills. }\end{array}$ & 1 & 2 & 3 & 4 & 5 \\
\hline 17. & I like to talk about computers with others. & 1 & 2 & 3 & 4 & 5 \\
\hline 18. & A computer is a useful tool for reading English. & 1 & 2 & 3 & 4 & 5 \\
\hline 19. & $\begin{array}{l}\text { Computer-Assisted Language Learning is more } \\
\text { interesting than traditional EFL instruction. }\end{array}$ & 1 & 2 & 3 & 4 & 5 \\
\hline 20. & $\begin{array}{l}\text { Using computers to learn English can enhance my } \\
\text { English proficiency. }\end{array}$ & 1 & 2 & 3 & 4 & 5 \\
\hline 21 & I am eager to study English through CALL. & 1 & 2 & 3 & 4 & 5 \\
\hline 22. & A computer is a useful tool for writing English. & 1 & 2 & 3 & 4 & 5 \\
\hline 23. & Reading English on computer does not bother me. & 1 & 2 & 3 & 4 & 5 \\
\hline 24. & The CALL lab has sufficient technical support. & 1 & 2 & 3 & 4 & 5 \\
\hline 25. & $\begin{array}{l}\text { The teachers have sufficient knowledge of CALL lab } \\
\text { procedures. }\end{array}$ & 1 & 2 & 3 & 4 & 5 \\
\hline 26. & $\begin{array}{l}\text { I would spend more hours in the CALL lab if it were } \\
\text { possible. }\end{array}$ & 1 & 2 & 3 & 4 & 5 \\
\hline 27. & I feel at ease working in the CALL lab. & 1 & 2 & 3 & 4 & 5 \\
\hline 28. & I am interested in CALL. & 1 & 2 & 3 & 4 & 5 \\
\hline 29. & $\begin{array}{l}\text { What I do in the CALL lab helps me in the regular } \\
\text { classroom courses. }\end{array}$ & 1 & 2 & 3 & 4 & 5 \\
\hline 30. & I often read computer-related information. & 1 & 2 & 3 & 4 & 5 \\
\hline
\end{tabular}

Finally, do you have any comment or add something?

Thank you for your participation. 


\section{Appendix B: The Arabic Version of the Survey For Men and Women Students}

$$
\text { بسم الله الرحمن الرحيم }
$$

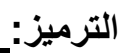

\section{مُقدِّمة}

أخى المشاركَ بَالاستبيانَ،

السلامُ عليكمْ ورحمةُ اللهِ وبركاته،،، ،

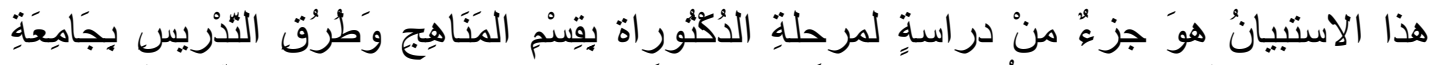

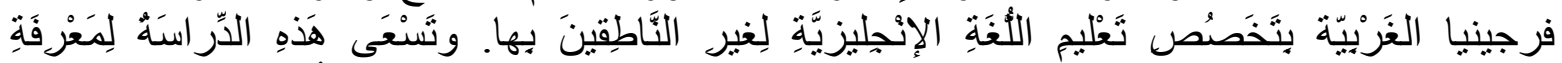

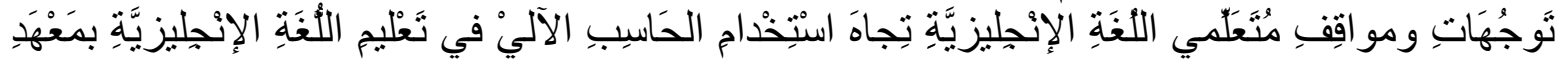

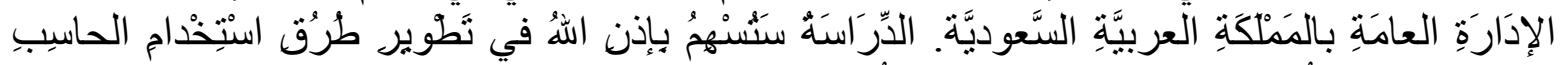

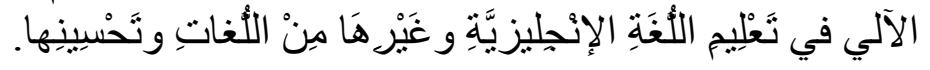

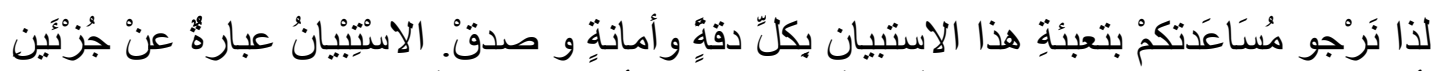

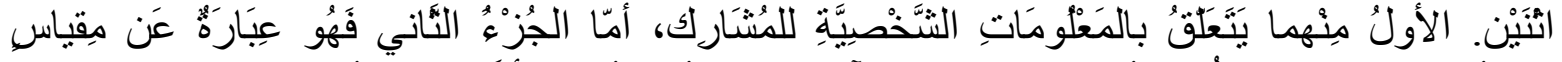

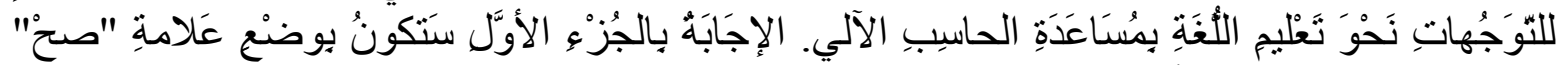

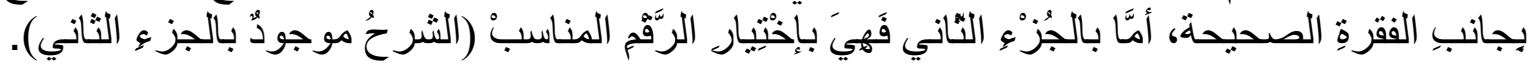

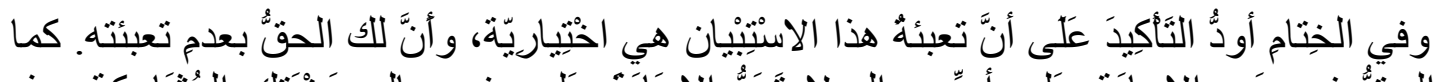

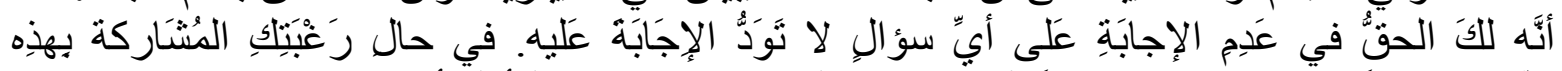

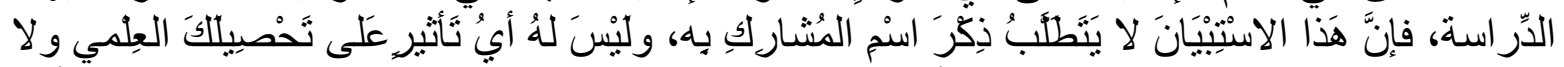

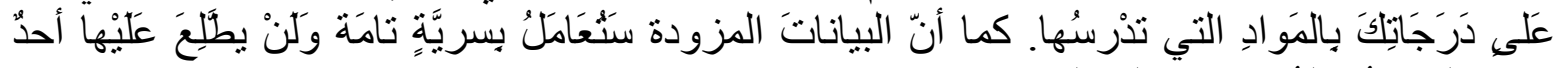

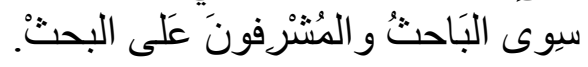

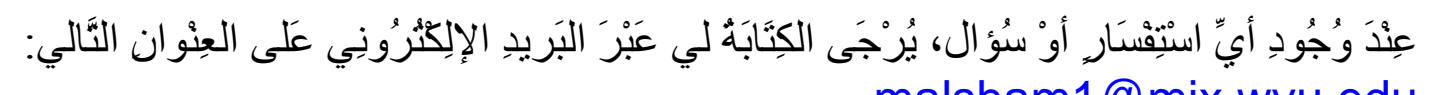
malsham1@mix.wvu.edu

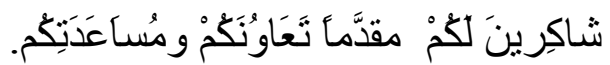
ولكَّْ صَادُقُ النَّحية.

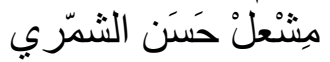
جامعة فرجينيا الغربية الو لايات المتحدة الأمريكية 
عنوان البريد الإكتروني: malsham1@mix.wvu.edu 


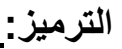

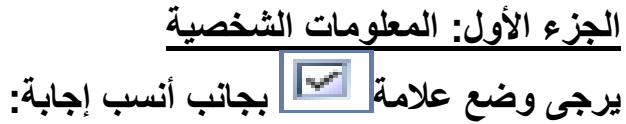

$$
\begin{aligned}
& \text { 1. مكان الدراسة بمعهُ الإدارة العامة: }
\end{aligned}
$$

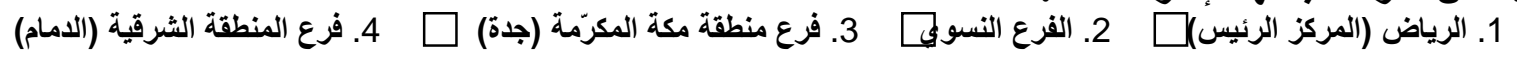

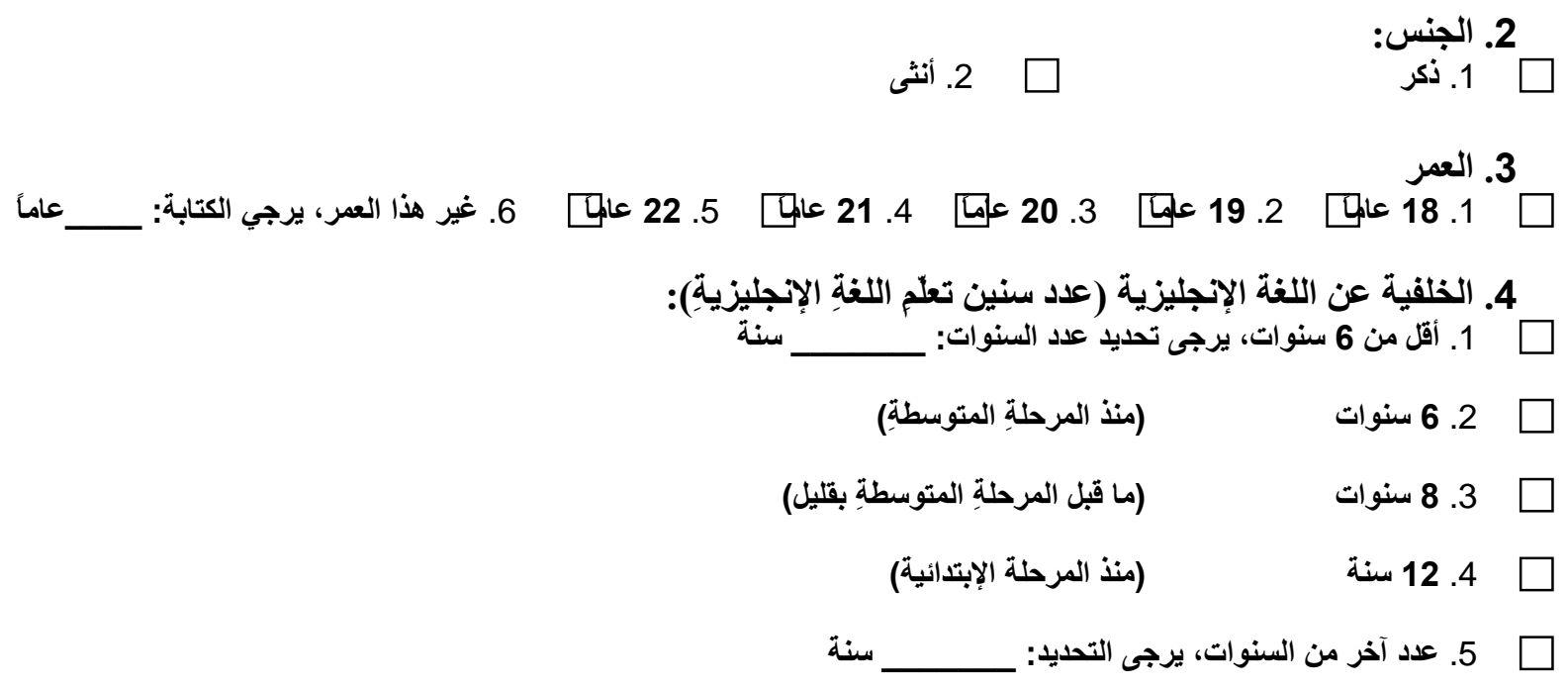

5. المستوى الاراسي الحالي بمركز اللغة الإنجليزية بمعهُ الإدارةٍ العامةً: (Elementary)( الأبتائية:

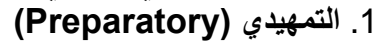

$$
\text { 3. }
$$

6. برنامجك الاراسي بالمعهد بعد إنهاء برنامج اللغة الإنجليزية:

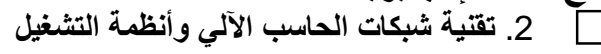

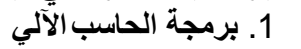

4. إدارة المستثفيات 3. السكرتير التنفيذي

6. المبيعات 5. (المحاسبة التجارية

8. دراسات المعومات والمكتبات 7. - الأعمال البنكية 9. تخصص آخر (يرجي كتابة اسم التخصص)

7. هل تملك حاسباً شخصياً؟

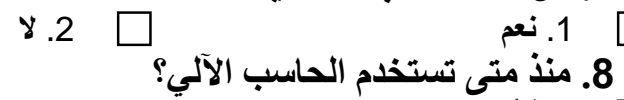
8. منذ متثى تستخدم الحاسب الآلي؟

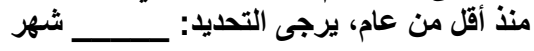
منذ عام منذ عامين منذ ثلاثةِ أعوام

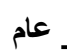
أكثر من ثُلاثةِّة أعوام، يرجى التحديد: 
9. كم ساعة تستخدم الحاسب الآلي يومياً (خارج المعهد) :

دقيقة

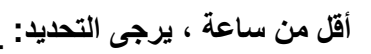

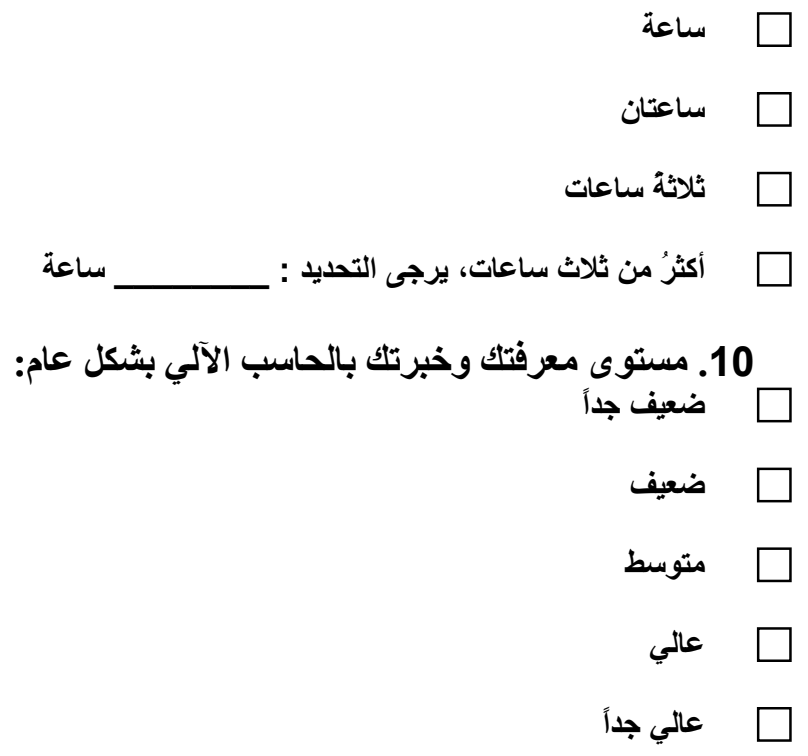


الجزء الثانى: قياس توجهات متعلى اللغة الإنجليزيَّة تجاه تطلم اللغة الإنجليزيَّة بمساعدة الحاسب الآلى:

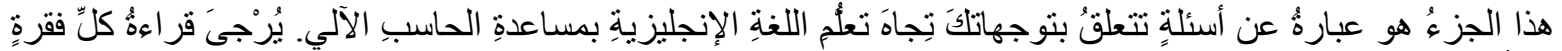

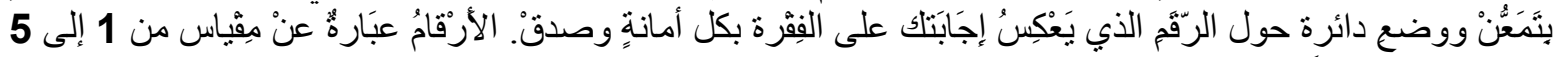

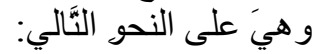
اختيارك لرقم 1 يعني لا أوافق بثدة على الفئي الذكور بالفقرة

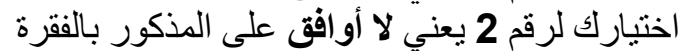

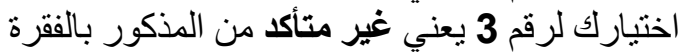

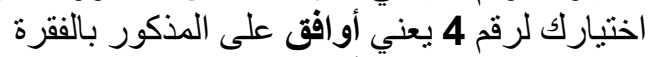
اختيارك لرقم 5 يعني أوافق بثدة على المذكور بالفئرة

\begin{tabular}{|c|c|c|c|c|c|c|}
\hline 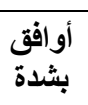 & أوافق & متأكد & لا أوافق & بل أوافق & 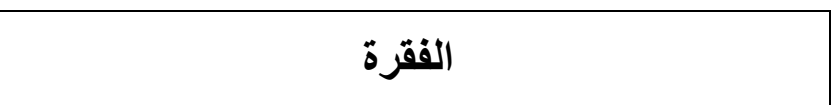 & الرقم \\
\hline 5 & 4 & 3 & 2 & 1 & 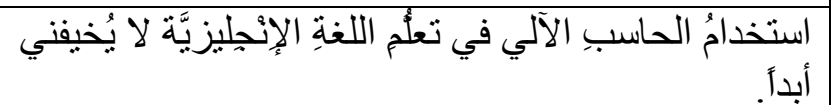 & .1 \\
\hline 5 & 4 & 3 & 2 & 1 & 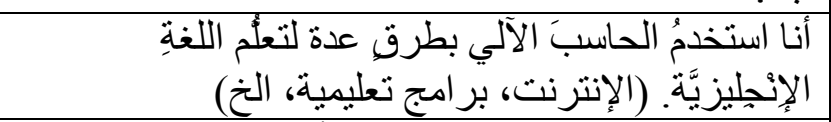 & .2 \\
\hline 5 & 4 & 3 & 2 & 1 & من الإنجليزيَّة. استخدامُ الحاسب الآلي لأداءو واجباتِ اللغةٍ & .3 \\
\hline 5 & 4 & 3 & 2 & 1 & 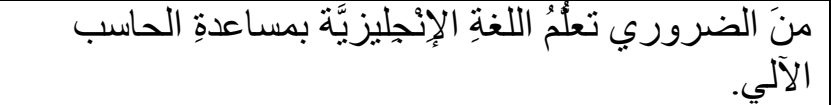 & .4 \\
\hline 5 & 4 & 3 & 2 & 1 & 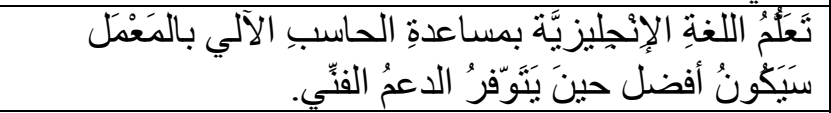 & .5 \\
\hline 5 & 4 & 3 & 2 & 1 & 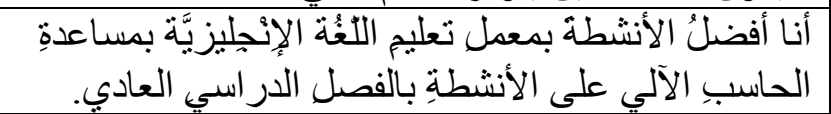 & .6 \\
\hline 5 & 4 & 3 & 2 & 1 & 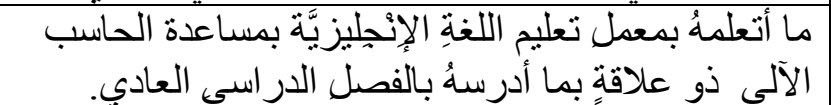 & .7 \\
\hline 5 & 4 & 3 & 2 & 1 & 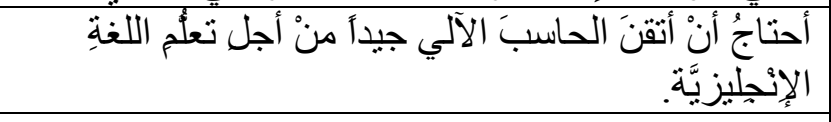 & .8 \\
\hline 5 & 4 & 3 & 2 & 1 & الحاسبُ الآلي يجعلُ تَعلَمَ اللغغة الإنِجليزيَّة أكثرُ سهولة. & .9 \\
\hline 5 & 4 & 3 & 2 & 1 & 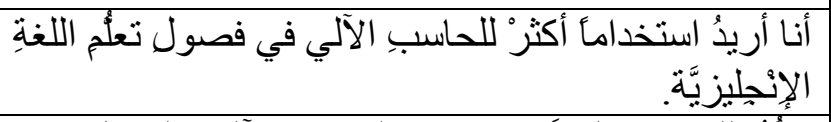 & .10 \\
\hline 5 & 4 & 3 & 2 & 1 & 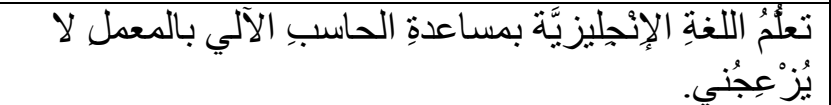 & .11 \\
\hline 5 & 4 & 3 & 2 & 1 & 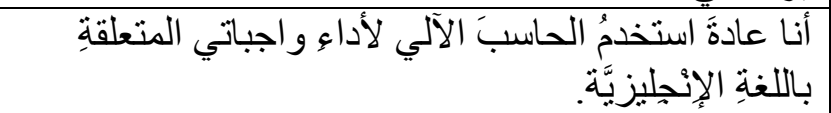 & .12 \\
\hline 5 & 4 & 3 & 2 & 1 & 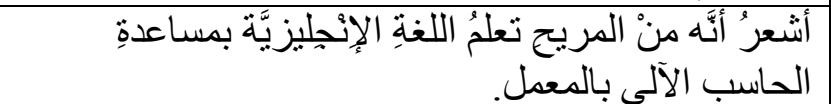 & .13 \\
\hline 5 & 4 & 3 & 2 & 1 & 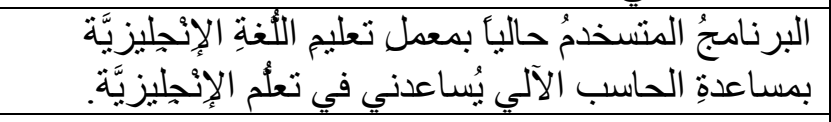 & .14 \\
\hline 5 & 4 & 3 & 2 & 1 & الكتابة بالحاسب الآلي لا ثُزِْْجُني. & .15 \\
\hline
\end{tabular}




\begin{tabular}{|c|c|c|c|c|c|c|}
\hline 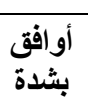 & أوافق & متأكد & لا أوافق & ل ألأوافق & 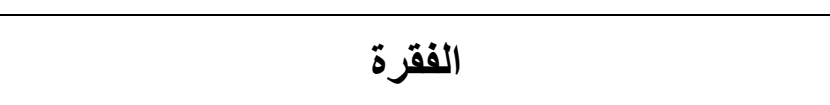 & الرقم \\
\hline 5 & 4 & 3 & 2 & 1 & 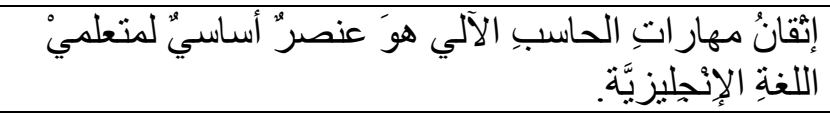 & .16 \\
\hline 5 & 4 & 3 & 2 & 1 & أحبُ التَّددثَ مع الآخرينَ عن الحاسب الآلي. & .17 \\
\hline 5 & 4 & 3 & 2 & 1 & الحاسبُ الآلي أداةٌ جيدةُ لتعلُم القر اءةٍ بالإنجِجليزيَّة. & .18 \\
\hline 5 & 4 & 3 & 2 & 1 & 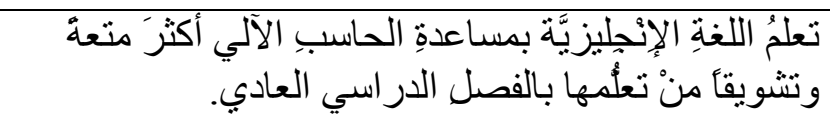 & .19 \\
\hline 5 & 4 & 3 & 2 & 1 & 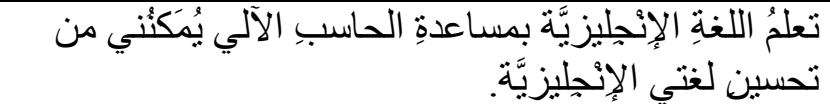 & .20 \\
\hline 5 & 4 & 3 & 2 & 1 & 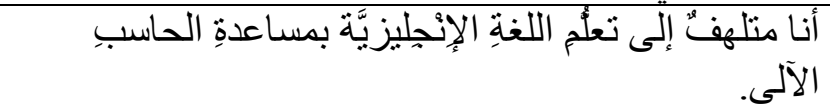 & .21 \\
\hline 5 & 4 & 3 & 2 & 1 & 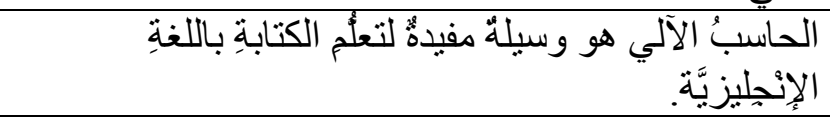 & .22 \\
\hline 5 & 4 & 3 & 2 & 1 & قر اءهُ اللغةِة الإنجِجليزيَّة بالحاسب الآلي لا ثُزْجِجُني. & .23 \\
\hline 5 & 4 & 3 & 2 & 1 & 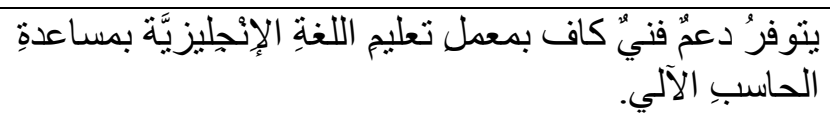 & .24 \\
\hline 5 & 4 & 3 & 2 & 1 & 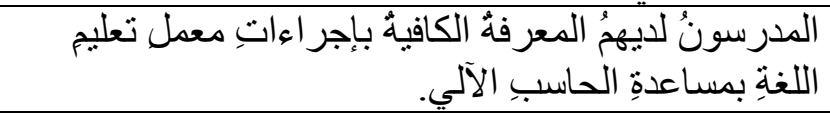 & .25 \\
\hline 5 & 4 & 3 & 2 & 1 & 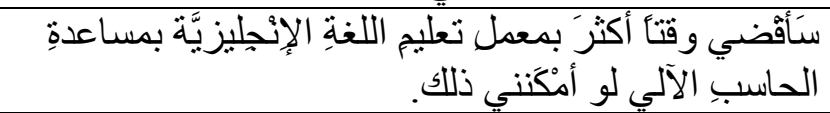 & .26 \\
\hline 5 & 4 & 3 & 2 & 1 & 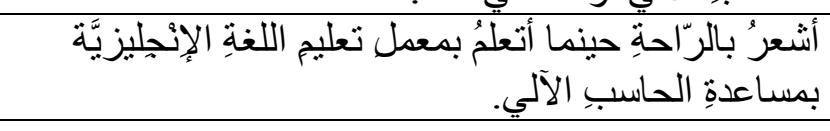 & .27 \\
\hline 5 & 4 & 3 & 2 & 1 & 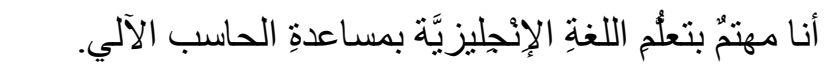 & .28 \\
\hline 5 & 4 & 3 & 2 & 1 & 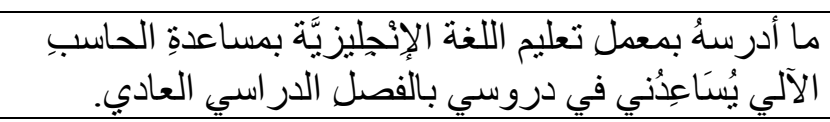 & .29 \\
\hline 5 & 4 & 3 & 2 & 1 & أنا عادةً أقر أ المعلوماتٍ المتعلقةٍة بالحاسب الآلي. & .30 \\
\hline
\end{tabular}

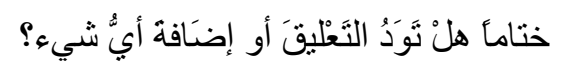




\title{
The Arabic Version of the Survey for Women Students
}

\author{
بسم اله الرحمن الرحيم
}

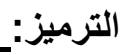

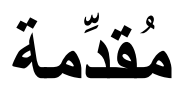

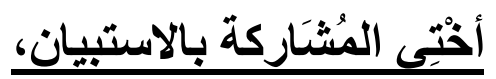

السلامُ عليكْ ورحمةُ اللهِ وبركاته، ،،

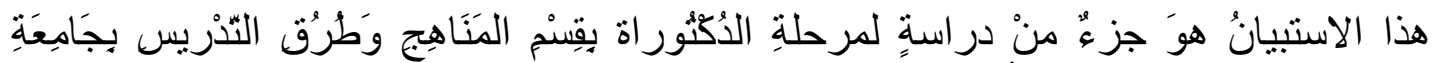

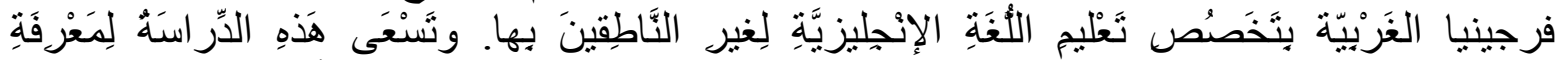

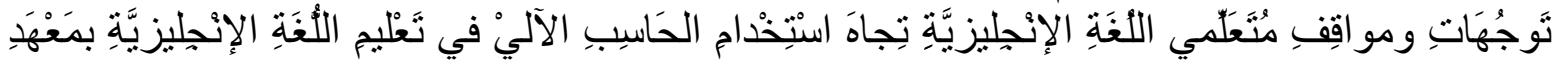

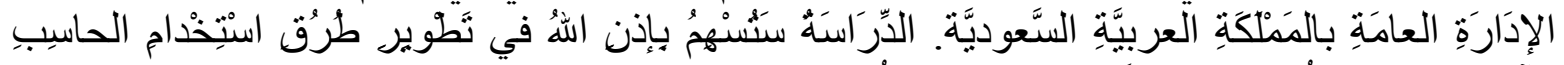

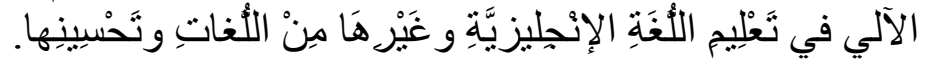

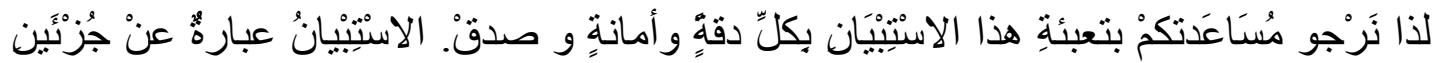

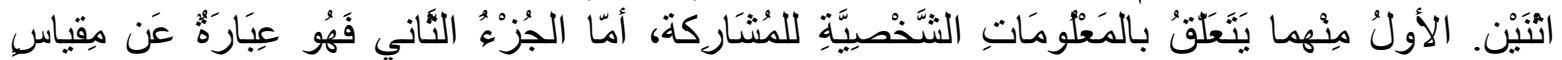

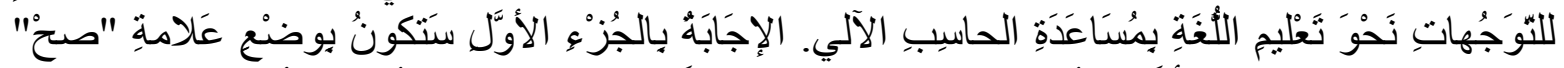

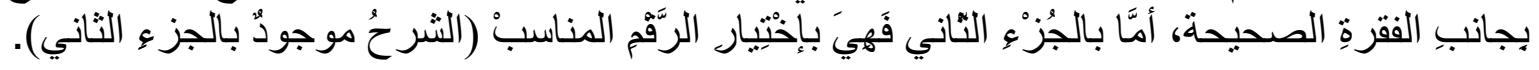

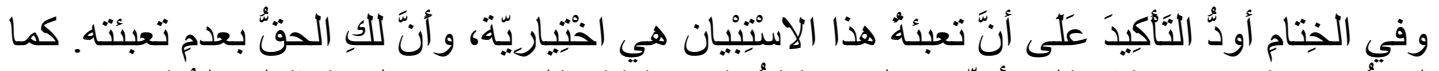

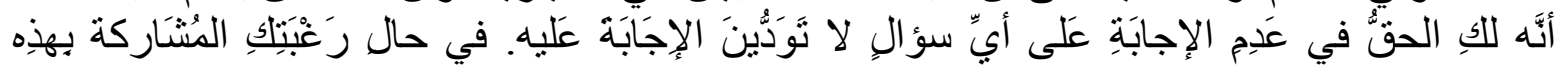

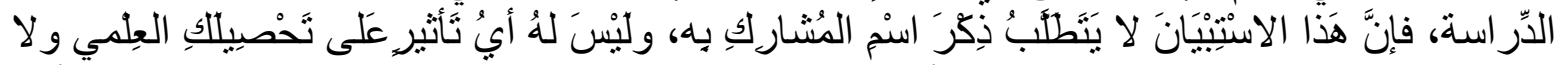

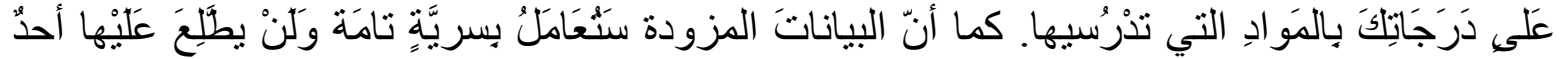

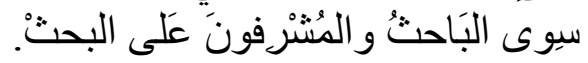

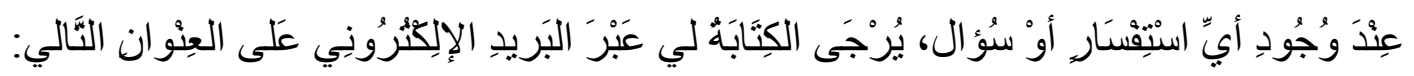
malsham1@mix.wvu.edu

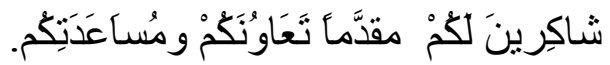
ولكَّْ صَادُقُ النَّحية.

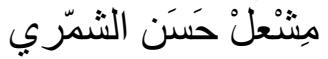
جامعة فرجينيا الغربية التربية الو لايات المتحدة الأمريكية الإنية

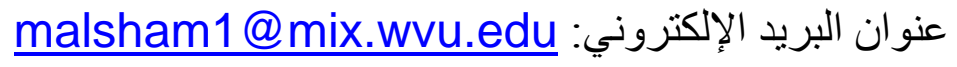




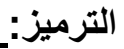

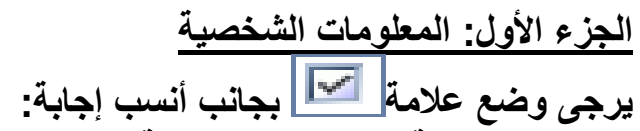

$$
\begin{aligned}
& \text { 1. مكان الاراسة بمعهد الإدارة العامة: العبا: }
\end{aligned}
$$

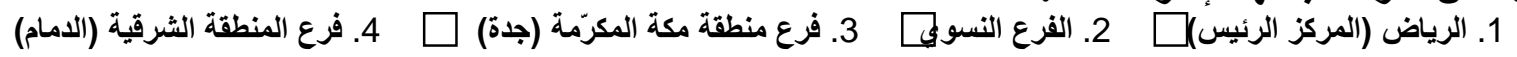

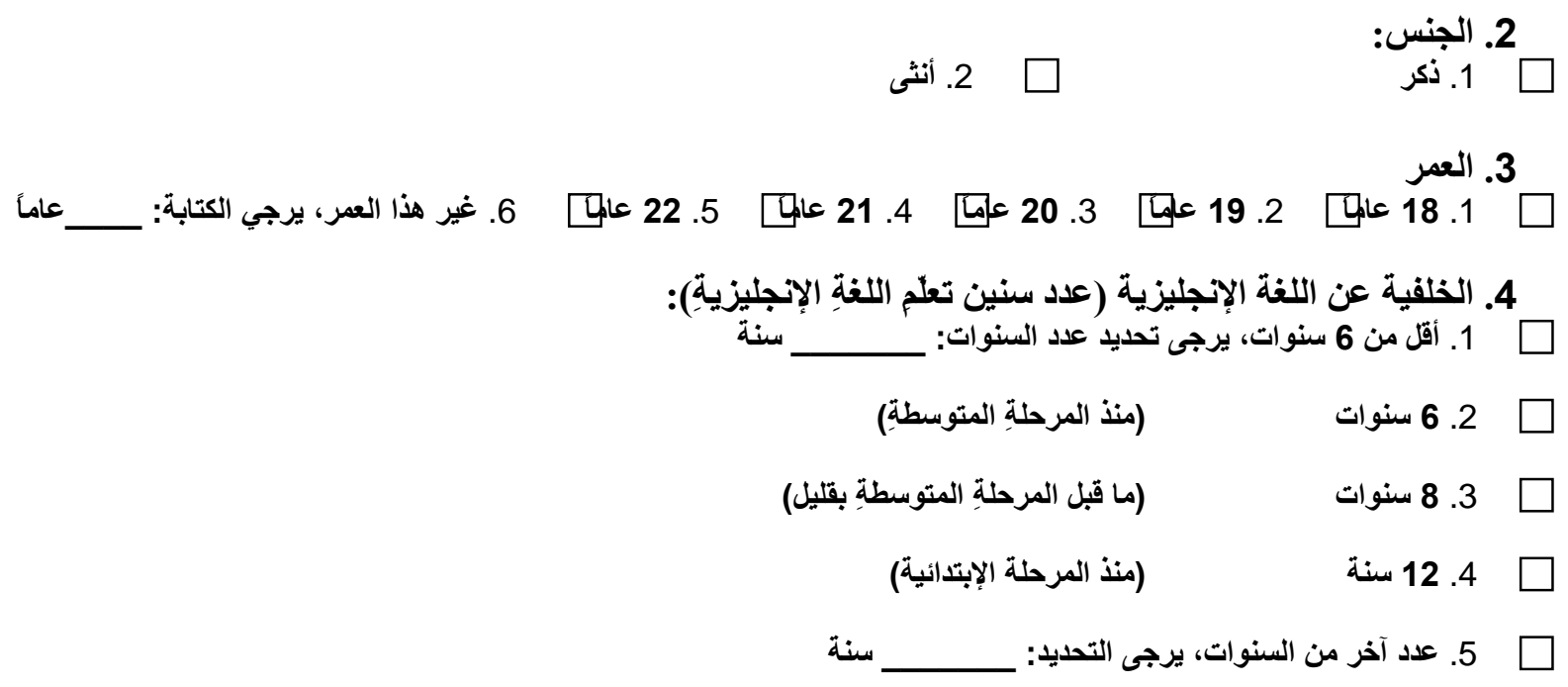

5. المستوى الدراسي الحالي بمركز اللغة الإنجليزية بمعهـ الإدارةٍ العامةِ: (Elementary)( الأبتائية:

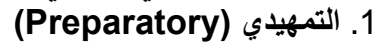

(Advanced) (المتقم)

3.

6. برنامجك الدراسي بالمعها بعد إنهاء برنامج اللغة الإنجليزية:

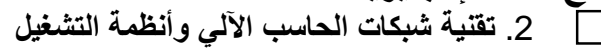

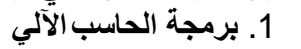

4. إدارة المستثفيات 3. السكرتير التنفيذي

6. - المبيعات

5. المحاسبة التجارية

8. دراسات المعلومات والمكتبات 7. - الأعمال البنكية 9. تخصص آخر (يرجي كتابة اسم التخصص)

7. هل تملك حاسباً شخصياً؟

У. 2 1. نعم هن

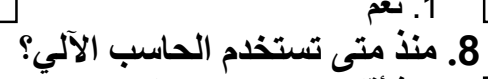

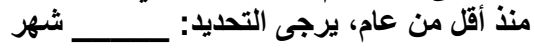
منذ عام منذ عامين منذ ثلاثةً أعوام

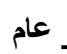
أكثر من ثُلاثةِّة أعوام، يرجى التحديد: 
9. كم ساعة تستخدم الحاسب الآلي يومياً (خارج المعهل) :

دقيقة

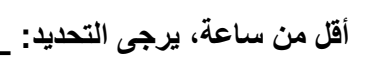

口

口

ثلاثة ساعات

ساعة

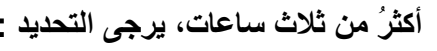

10. مستوى معرفتك وخبرتك بالحاسب الآلي بشكل عام:

ض ضعيف جدأ

ضعيف $\square$

متوسط

$\square$

عالي جداً 
الجزء الثانى: قياس توجهات متطلى اللفة الإنجليزيَّة تجاه تطلم اللغة الإنجليزيَّة بمساعدة الحاسب الآلى:

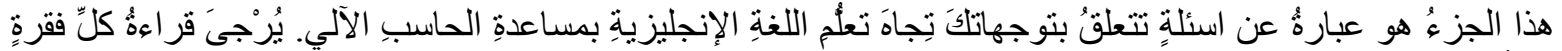

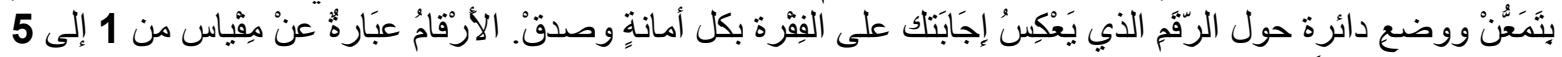

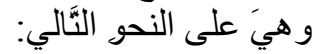

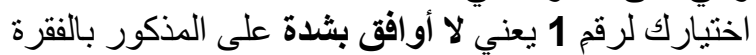

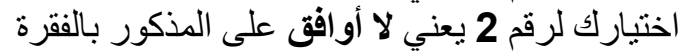

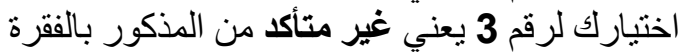

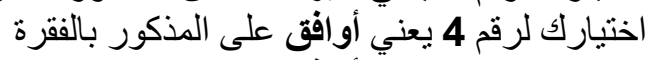
اختيارك لرقم 5 يعني أوافق بثدة على المذكور بالفئرة

\begin{tabular}{|c|c|c|c|c|c|c|}
\hline 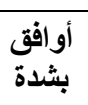 & أوافق & متأكد & لا أوافق & بل أوافق & الفقرة & الرقم \\
\hline 5 & 4 & 3 & 2 & 1 & 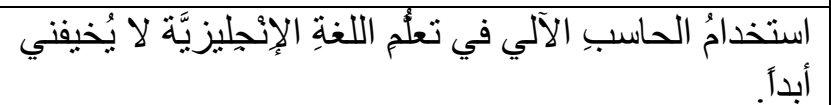 & .1 \\
\hline 5 & 4 & 3 & 2 & 1 & 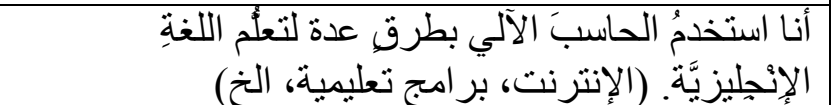 & .2 \\
\hline 5 & 4 & 3 & 2 & 1 & 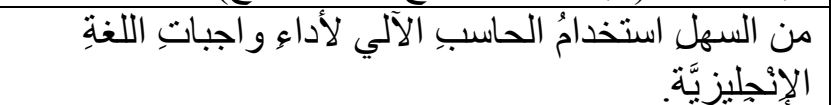 & .3 \\
\hline 5 & 4 & 3 & 2 & 1 & مالَّلَ الضروري تعُلمُ اللغةِة الإنجِليزيَّة بمساعدةٍ الحاسب & .4 \\
\hline 5 & 4 & 3 & 2 & 1 & 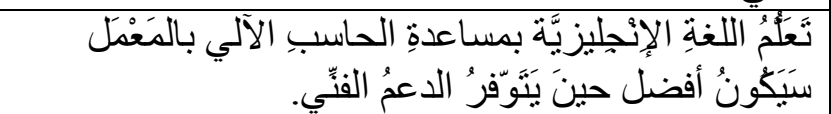 & .5 \\
\hline 5 & 4 & 3 & 2 & 1 & 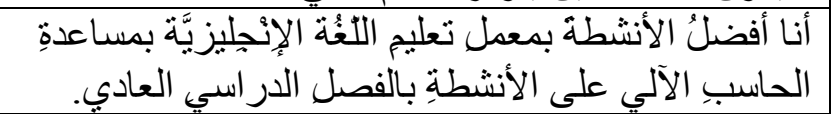 & .6 \\
\hline 5 & 4 & 3 & 2 & 1 & 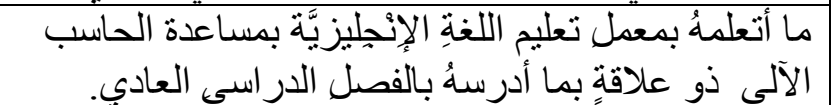 & .7 \\
\hline 5 & 4 & 3 & 2 & 1 & 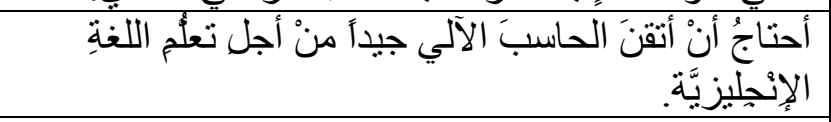 & .8 \\
\hline 5 & 4 & 3 & 2 & 1 & الحاسبُ الآلي يجعلُ تَعلمَ اللغةِ الإنجليزيَيَّة أكثرُ سهولة. & .9 \\
\hline 5 & 4 & 3 & 2 & 1 & 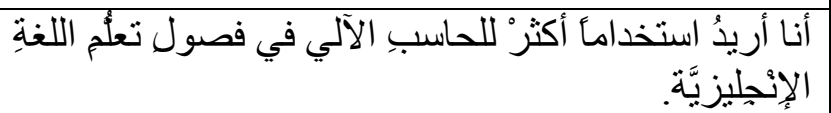 & .10 \\
\hline 5 & 4 & 3 & 2 & 1 & 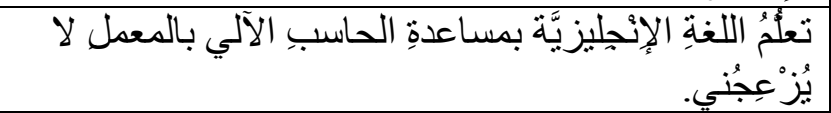 & .11 \\
\hline 5 & 4 & 3 & 2 & 1 & 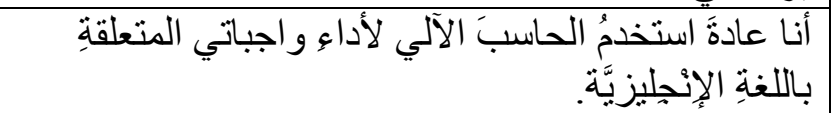 & .12 \\
\hline 5 & 4 & 3 & 2 & 1 & 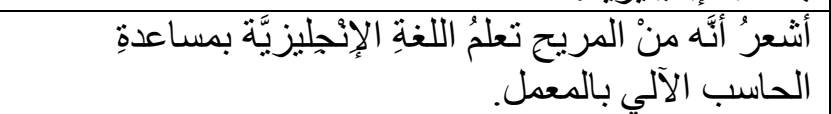 & .13 \\
\hline 5 & 4 & 3 & 2 & 1 & 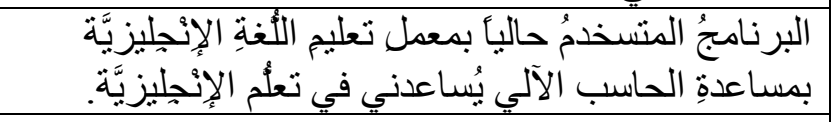 & .14 \\
\hline 5 & 4 & 3 & 2 & 1 & الكتابة بالحاسب الآلي لا ثُزِْْجُني. & .15 \\
\hline
\end{tabular}




\begin{tabular}{|c|c|c|c|c|c|c|}
\hline 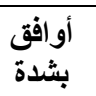 & 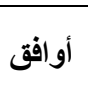 & متأكد & لا أوافق & 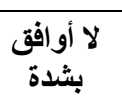 & 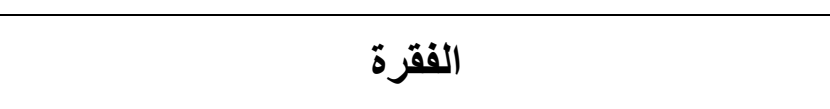 & الرقم \\
\hline 5 & 4 & 3 & 2 & 1 & 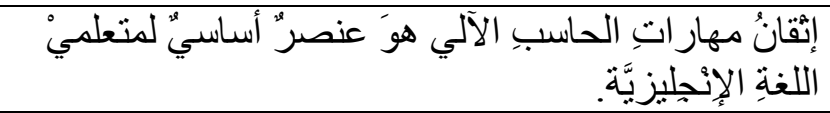 & .16 \\
\hline 5 & 4 & 3 & 2 & 1 & أحبُ النَّحدثَ مع الآخرينَ عن الحاسب الآلي. & .17 \\
\hline 5 & 4 & 3 & 2 & 1 & الحاسبُ الآلي أداةٌ جيدةٌ لتعلُم القر اءةٍ بالإنجِليزيَّة. & .18 \\
\hline 5 & 4 & 3 & 2 & 1 & 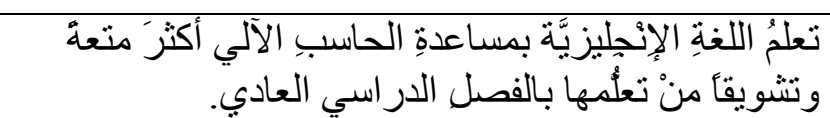 & .19 \\
\hline 5 & 4 & 3 & 2 & 1 & 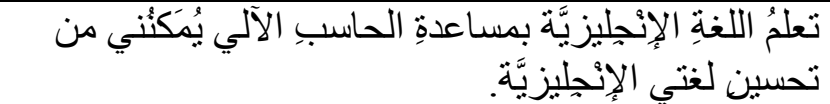 & .20 \\
\hline 5 & 4 & 3 & 2 & 1 & 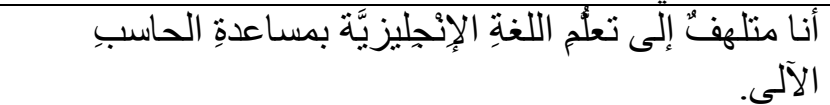 & .21 \\
\hline 5 & 4 & 3 & 2 & 1 & 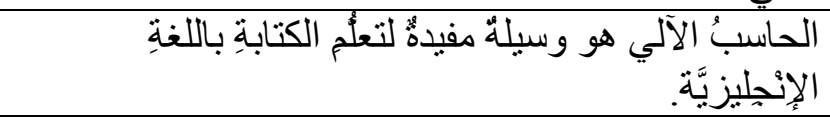 & .22 \\
\hline 5 & 4 & 3 & 2 & 1 & قر اءهُ اللغةِة الإنجِجليزيَّة بالحاسب الآلي لا ثُزْجِجُني. & .23 \\
\hline 5 & 4 & 3 & 2 & 1 & 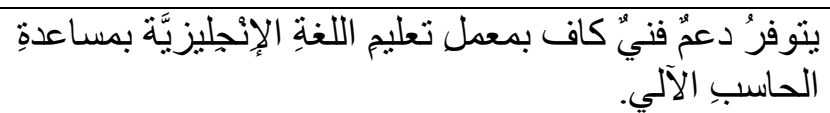 & .24 \\
\hline 5 & 4 & 3 & 2 & 1 & 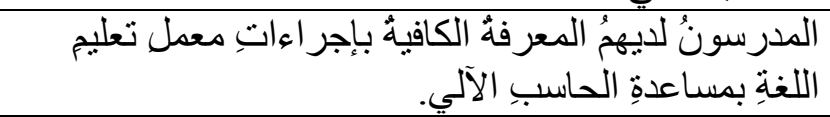 & .25 \\
\hline 5 & 4 & 3 & 2 & 1 & 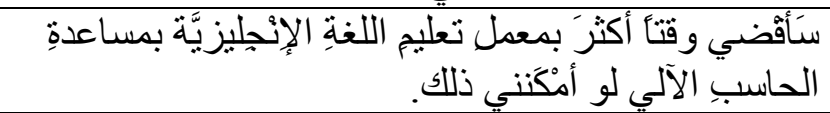 & .26 \\
\hline 5 & 4 & 3 & 2 & 1 & 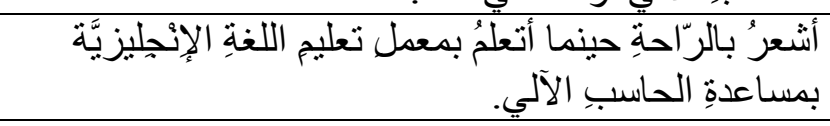 & .27 \\
\hline 5 & 4 & 3 & 2 & 1 & 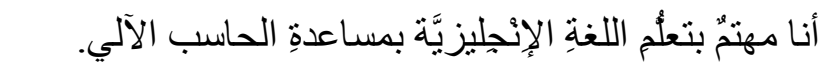 & .28 \\
\hline 5 & 4 & 3 & 2 & 1 & 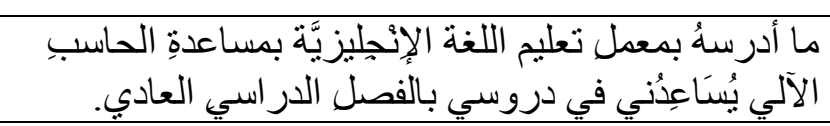 & .29 \\
\hline 5 & 4 & 3 & 2 & 1 & أنا عادةً أقر أ المعلوماتٍ المتعلقةٍ بالحاسب الآلي. & .30 \\
\hline
\end{tabular}

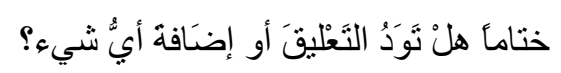




\section{Appendix C: Permission to Adopt CAS Survey}

From: Doug Loyd, IAAS <del6n@virginia.edu>

Reply-To: del6n@virginia.edu

To: malsham1@mix.wvu.edu

Date: May 18, 2006 7:16 AM

Subject: Loyd/Gressard Computer Attitude Scale

Reply | Reply to all | Forward | Print | Add sender to Contacts list | Delete this message |

Report phishing | Show original | Message text garbled?

Thank you for your inquiry about the Computer Attitude Scale.

As you may know, Brenda Loyd, author of the CAS, was President of the National Council on Measurement in Education (NCME) at the time of her death in 1995. Dr. Loyd's co-author, Clarice Gressard, has asked me to handle all requests for permission to use their survey, and to provide the CAS survey and scoring protocol to researchers who wish to use their scale.

Therefore, in response to your inquiry, I am attaching a copy of the Loyd/Gressard survey of attitudes towards computers, in an MSWord document (survey.doc). If you have any problem reading it please let me know. Unfortunately I have no further information about the use of the CAS beyond that provided in this message and the attached document.

The survey is scored according to the following:

For questions $1,3,4,6,9,11,12,14,16,17,19,22,25,27,28$, 30, 33, 35, 36, 38 (Strongly Agree=4, Slightly Agree=3, Slightly Disagree $=2$, Strongly Disagree=1).

For questions $2,5,7,8,10,13,15,18,20,21,23,24,26,29,31$, 32, 34, 37, 39, 40 (Strongly Agree=1, Slightly Agree=2, Slightly Disagree $=3$, Strongly Disagree=4).

The questions are coded so that the higher the score, the more positive the attitude.

Four subscores can also be obtained from the questions.

Anxiety:

$1,5,9,13,17,21,25,29,33,37$

Confidence:

$2,6,10,14,18,22,26,30,34,38$

Liking:

$3,7,11,15,19,23,27,31,35,39$

Usefulness:

$4,8,12,16,20,24,28,32,36,40$ 
Again, higher scores correspond to more positive attitude, e.g., a higher confidence score means more confidence and a higher anxiety score means less anxiety.

Permission is granted for modification and use of this scale. In any publications arising from its use, please be sure to credit the authors, Brenda H. Loyd and Clarice P. Gressard.

Thanks for your interest.

Best wishes.

Doug Loyd

Attachment: Survey.doc (MSWord)

Doug Loyd, Ph.D. 434-924-0993 FAX 434-982-2858

Office of Institutional Assessment and Studies, UVa 


\section{Permission to adopt SETA Survey}

ydpc<ydpc@mail.ncku.edu.tw> to Mishal

From: ydpc <ydpc@mail.ncku.edu.tw>

Hide options May 18

To: Mishal Hassan AIShammari <malsham1@mix.wvu.edu>

Date: May 18, 2006 3:37 AM

Subject: Re: SETA Scale

Reply | Reply to all | Forward | Print | Add sender to Contacts list | Delete this message |

Report phishing | Show original | Message text garbled?

Dear Mr. Shammari,

You are welcome to use the Scale of Educational Technology Attitudes (SETA)

designed by myself in your dissertation.

It is quite interesting for me to learn that

a comparative study about the similar research topic will be done in Saudi

Arabia.

I expect to hear the results of the study when you have them.

Sincerely,

Pi-Ching Chen

Associate Professor and Chairman

Dept. of Foreign Languages and Literature

National Cheng Kung University

Taiwan, R. O. C.

TEL: 886-6-2757575 ext. 52201

FAX: 886-6-2387730 


\section{Appendix D: Survey Evaluation Form}

Dear Participant,

This survey aims to collect data on EFL learners' attitudes toward ComputerAssisted Language Learning (CALL). Please fill out the attached survey first and then complete the evaluation form by checking the most correct response for each item. Your responses will help improve the quality of the survey and put it in its final form to reflect the goal that it was designed to accomplish.

1. Time required completing the survey:

$\square$ Less than 10 minutes $\square$ From 10 to 15 minutes

$\square$ From 15 to 20 minutes $\square$ More than 20 minutes

2. The survey's items were:

$\square$ Clear and easy to understand.

$\square$ Diffuse, but I could complete the survey.

$\square$ Not clear and hard to understand.

3. When I read the survey, I found that:

All the words were clear and understandable.

$\square$ Some words were not clear, but they did not influence my answers.

$\square$ Some words were completely unclear and influenced my answers.

4. Please circle the number of items that you found it difficult to understand and provide your suggestion or comments to help making it more clear and understandable.

Part 1: Demographic Items

$\begin{array}{llllllllll}\text { Item no: } 1 & 2 & 3 & 4 & 5 & 6 & 7 & 8 & 9 & 10\end{array}$ Suggestions or Comments: 
Part 2: Scale of Attitudes toward CALL (SACALL)

$\begin{array}{llllllllll}\text { Item no: } 1 & 2 & 3 & 4 & 5 & 6 & 7 & 8 & 9 & 10\end{array}$

$\begin{array}{llllllllll}11 & 12 & 13 & 14 & 15 & 16 & 17 & 18 & 19 & 20\end{array}$

$\begin{array}{llllllllll}21 & 22 & 23 & 24 & 25 & 26 & 27 & 28 & 29 & 30\end{array}$

Suggestions or Comments:

5. Do you want to add any suggestions or comments?

Thank you very much for your participation. 


\title{
Appendix E:Arabic Form of the Survey
} Evaluation

\author{
بسم الله الرحمن الرحيم \\ نموذج تقييم الاستبيان
}

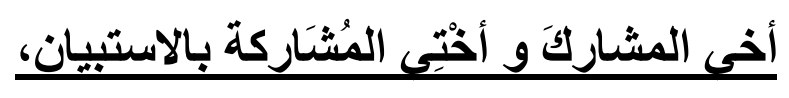

السلام عليكم ورحمة الله وبركاته،،،

هدفُ هذا الاستبيان هو جمعُ بياناتٍ عن موقفب طلاب اللغة الإنجليزية كلغة أجنبية وتوجهاتهز

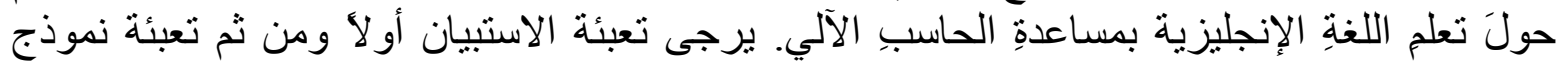

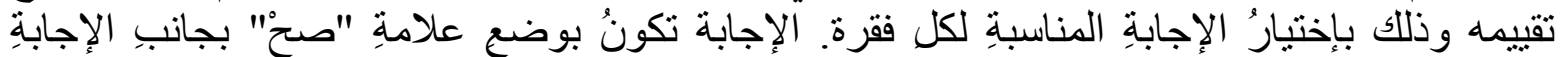

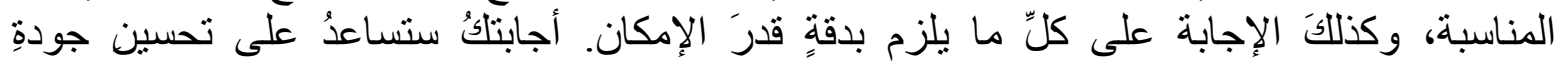

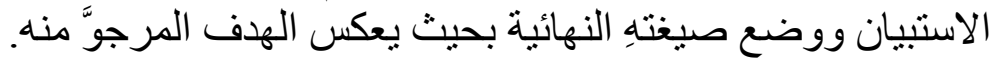
شاكرين لكم تعاو نكم ومساعدتكم.

$$
\begin{aligned}
& \text { أولاً: الوقت من الذي استغرقته الإجابة على الاستيبان: } 10 \text { من } 10 \text { دقائق إلى } 15 \text { دقيقة }
\end{aligned}
$$

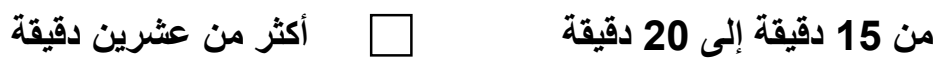

$$
\begin{aligned}
& \text { هانياً: فقراتُ الاستبيان كانت: } \\
& \text { كثيرة، ولكن أمكنتي الفهم ومواصلة الإجابة على الاستبيان } \\
& \text { غير مفهومة وغير واضحة ومن الصعب استيعابها والإجابة عليها } \\
& \text { ثاثثاً: عند قراعتى مفردات الاستيبان، وجدت أنَّة: } \\
& \text { كل مفردات الاستبيان واضحةُ وسهلئة الفهر } \\
& \text { بعض مفرداته غير مفهومة، ولكنها ماكاتت لتأثرَّ على قدرتي على الإجابة } \\
& \text { بعض المفردات لم تكن واضحة بحيثُ أثرت على قدرتي على الإجابة }
\end{aligned}
$$


رابعاً: يرجى وضع دائرة حول رقم الفقرة أو أرقام الفقرات التى وجدت صعوبة في فهمها، وكتابة تعليقً أو اقتراح

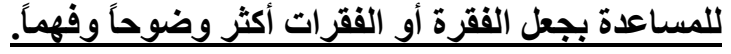

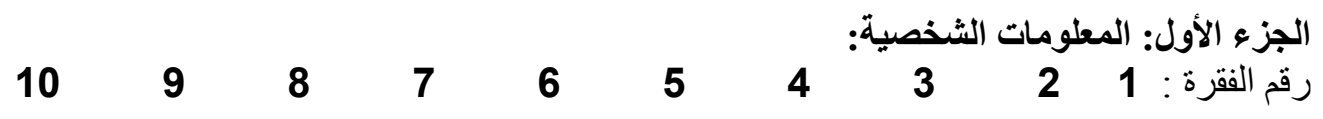
التعليق أو المقترح:

الجزء الثاني: مقياس توجهات متعلمي اللغة الإنجليزية تجاه تعلم اللغة الإنجليزية بمساعدة الحاسب الآلي:

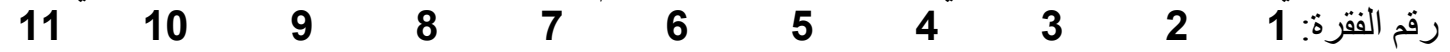
$\begin{array}{lllllllllll}22 & 21 & 20 & 19 & 18 & 17 & 16 & 15 & 14 & 13 & 12\end{array}$ $\begin{array}{llllllll}30 & 29 & 28 & 27 & 26 & 25 & 24 & 23\end{array}$ التعليق أو المقترح:

خامساً: هل تود/تودين التعليق أو الاقتراح على الاستبيان بشكل عام أو إضافة شىع؟ 


\section{Appendix F: Human Participant Protections Approval}

Human Participant Protections Education for Research Teams
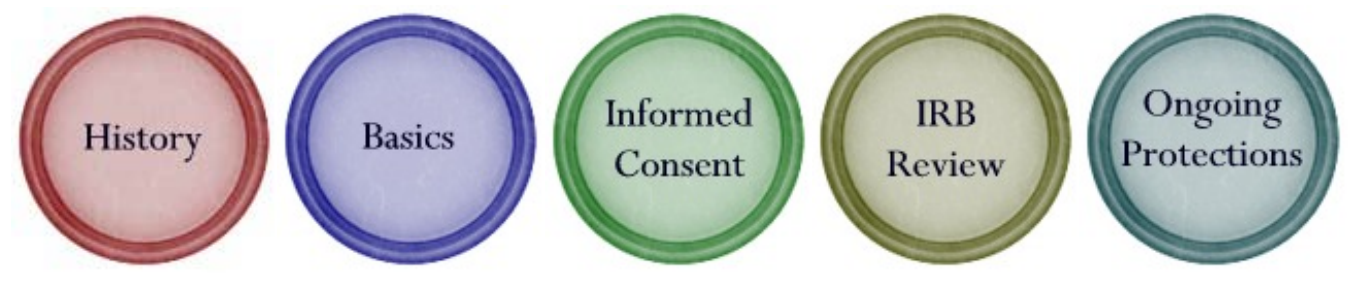

\section{Al Shammari, Michal has completed this course at West Virginia University.}

\section{Date of completion: 2/16/2006}

Specific topics addressed include:

- Roles and responsibilities of researchers and their key personnel

- Guiding ethical principles for research

- Federal regulations

- Informed consent

- Institutional review boards

- Ongoing protections throughout the course of the study

- Data and safety monitoring

- Reporting of adverse events

- Privacy and confidentiality

- Historical events that have impacted policy and legislation

\section{Research Compliance Office}

West Virginia University

\section{Please Note:}

- This certificate for Human Participant Protections Training is attached for your files.

- A copy is not required for our files in Research Compliance.

- Your training information has been added to the Research Compliance Database. A list of certified personnel, students and staff gets posted each week at http://www.wvu.edu/ rc/irb/hpp list.htm. 


\title{
Appendix G :Curriculum Vitae, Mishal H. Al Shammari
}

\author{
Mishal H. Al Shammari \\ 1342 Headlee Ave - Morgantown, WV 26505 \\ $304-2885658$ (H) 304-293-4376, (0) \\ e-mail: malsham1@mix.wvu.edu
}

\section{EDUCATION}

\author{
West Virginia University Morgantown, West Virginia, USA \\ Doctor of Education (Ed.D) - Curriculum and Instruction \\ August, 2007 \\ Dissertation: Saudi English as a Foreign Language Learners' \\ Attitudes toward Computer-Assisted Language \\ Learning
}

Coursework in Foundations and Theory

$\begin{array}{ll}\text { C\&I788 } & \text { Higher Education Curriculum } \\ \text { C\&I604 } & \text { Secondary School Curriculum } \\ \text { C\&I701 } & \text { Curriculum Development } \\ \text { C\&I707 } & \text { Theories, Models, and Research of Teaching } \\ \text { TE740 } & \text { Curriculum Development \& Technology } \\ \text { C\&I709 } & \text { Curriculum Theories } \\ \text { EDP700 } & \text { Psychological Foundations of Learning } \\ \text { C\&I593A } & \text { SPTP: Advanced Curriculum Specialization } \\ \text { EDP600 } & \text { Educational Psychology }\end{array}$

Coursework in Teaching Strategies

C\&I687 Advanced Teaching Strategies

C\&I688 Classroom Organization \& Management

LANG512 ESL Methods

EDP 610 Measurement/Assessment for the Classroom Teacher

C\&I 693A Performance Assessment

Coursework in Research

EDP612 Introduction to Research

BIBY615 Methods of Research

EDP613 Statistical Methods 1

EDP614 Statistical Methods 2

SCFD615 Qualitative Research Methods

West Virginia University Morgantown, West Virginia, USA

Master of Arts - Foreign Languages (TESOL and Linguistics)

December, 2004 


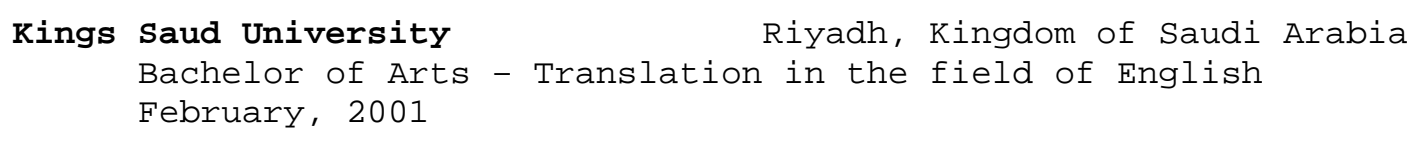

\title{
EXPERIENCE
}

\author{
Institute of Public Administration (IPA) Riyadh, Saudi Arabia \\ EFL instructor, Intensive English Program, \\ May, 2001 - Present \\ Responsible for a wide range of functions, including teaching \\ English language courses in grammar, reading, writing, oral, etc..., \\ participating in administrative functions and extracurricular \\ activities associated with the English Intensive Program, providing \\ training to IPA faculty members on how to use CALL labs, and \\ participating on IPA admissions and commencement committees.
}

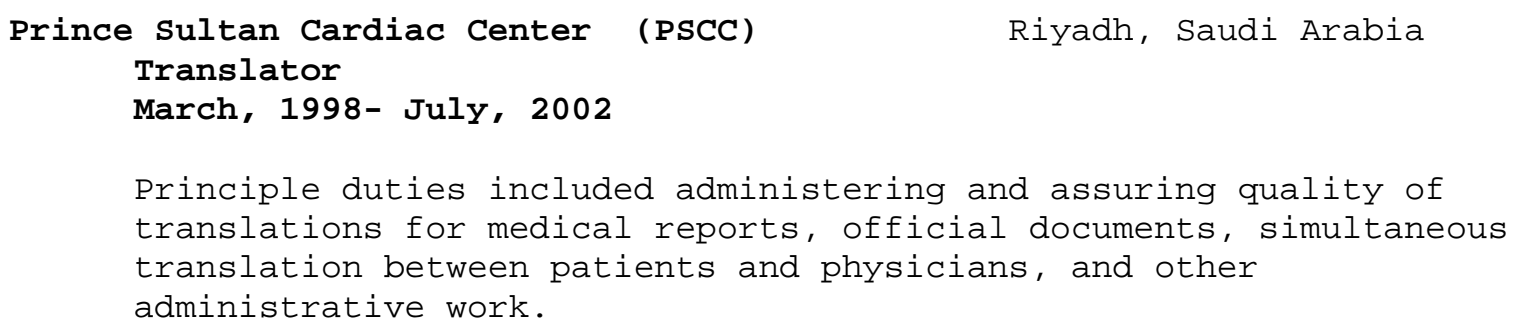

\section{other Information}

\section{Presentations}

Al Shammari, M. H. (2007, March). CALL Applications. Paper presented at the annual meeting of the TESOL Arabia, Dubai, United Arab Emirates.

\section{Languages:}

Arabic, Native Speaker English, Near Native

French, Novice 